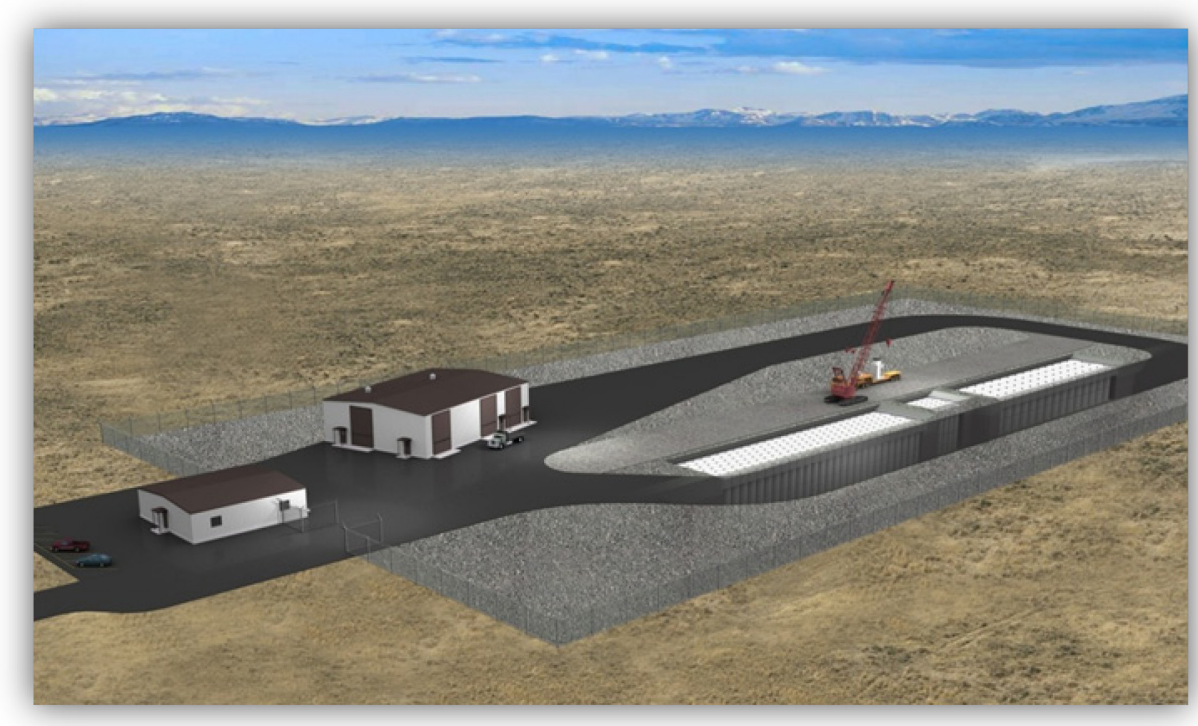

Remote-Handled Low-Level Waste Disposal Project Alternatives Analysis

Integrated Project Team

April 2011

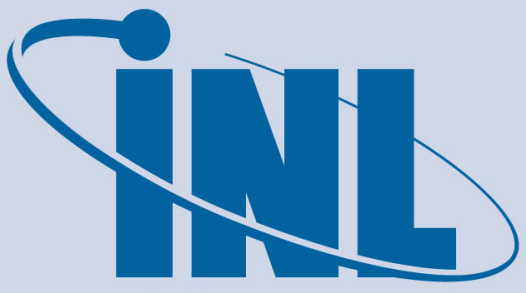

Idaho National

INL is a U.S. Department of Energy National

Laboratory operated by Battelle Energy Alliance Laboratory 



\title{
Remote-Handled Low-Level Waste Disposal Project Alternatives Analysis
}

\author{
Integrated Project Team
}

\author{
April 2011 \\ Idaho National Laboratory \\ Idaho Falls, Idaho \\ Prepared for the \\ U.S. Department of Energy \\ Office of Nuclear Energy \\ Under DOE Idaho Operations Office \\ Contract DE-AC07-05ID14517
}





\begin{abstract}
This report identifies, evaluates, and compares alternatives for meeting the U.S. Department of Energy's mission need for management of remote-handled low-level waste generated by the Idaho National Laboratory and its tenant.

Each alternative identified in the Mission Need Statement for the RemoteHandled Low-Level Waste Treatment Project is described and evaluated for capability to fulfill the mission need. Alternatives that could meet the mission need are further evaluated and compared using criteria of cost, risk, complexity, stakeholder values, and regulatory compliance.

The alternative for disposal of remote-handled low-level waste that has the highest confidence of meeting the mission need, presents the lowest risk to the public because highly radioactive shipments will not be in commerce, and represents best value to the government is to build a new disposal facility at the Idaho National Laboratory Site.
\end{abstract}




\section{EXECUTIVE SUMMARY}

This report presents an analysis of the alternatives for replacement disposal capability of remote-handled low-level waste (LLW) generated by the Idaho National Laboratory (INL), U.S. Department of Energy's (DOE's) Office of Nuclear Energy and its tenant, and the Office of Naval Reactors. This report has been prepared to support project planning under DOE Order 413.3B, "Program and Project Management for Acquisition of Capital Assets."

On July 1, 2009, DOE approved a mission need statement for the INL Remote-Handled LLW Disposal Project:

The INL will develop replacement remote-handled low-level waste disposal capability by the end of Fiscal Year 2015 to support cost-effective, efficient operations in support of INL's nuclear energy mission and the Naval Nuclear Propulsion Program. Such disposal capability is required to enhance ongoing Departmental and National mission-based research, defense, and energy programs.

INL routinely generates remote-handled LLW from facility operations. Historically, INL has disposed of its remote-handled LLW in the Subsurface Disposal Area of the Radioactive Waste Management Complex. This facility includes disposal pits and concrete vaults. However, this existing disposal facility is planned to be closed under INL's environmental management contract. The mission need date was later extended to Fiscal Year (FY) 2017 based on a 2-year extension of availability of the existing disposal vaults in the Subsurface Disposal Area. Section 1 provides an introduction to the project and the alternatives analysis.

This alternatives analysis was conducted to implement the project planning requirements of DOE Order 413.3B for conceptual design. The objective of this analysis is to identify an alternative for future remote-handled LLW disposal that will form the basis for the conceptual design to be submitted for Critical Decision-1 approval. A systematic approach was employed to achieve this objective, which involved defining future remote-handled LLW disposal needs, evaluating disposal alternatives, and recommending an alternative.

A range of possible alternatives for INL remote-handled LLW disposal were identified in the Mission Need Statement for the project, including alternatives that would use existing assets. Since then, no new alternatives have been identified. These alternatives are listed as follows:

1. Continued disposal at RWMC

2. Disposal at the Idaho Comprehensive Environmental Response, Compensation, and Liability Act Disposal Facility (ICDF)

3. Interim storage

4. Storage for decay 
5. Development of an onsite remote-handled LLW disposal facility

6. Offsite remote-handled LLW disposal (multiple locations)

7. Privatization of remote-handled LLW disposal

8. No action.

The approach used to assess the remote-handled LLW management alternatives and accomplish the objectives of this analysis is two-fold. First, the alternatives are reviewed for their potential to fulfill the mission need for replacement disposal capability of all INL Site remote-handled LLW through at least the year 2037, and second, alternatives that best meet the mission need are evaluated in detail and compared based on the discriminators of cost, risk, complexity, stakeholder values, and regulatory compliance. Execution of Step 1 of the process led to identification of two alternatives that best met the mission need: (1) development of a new onsite disposal facility, and (2) disposal offsite at the Nevada National Security Site (NNSS) (formerly known as the Nevada Test Site). The summary of the evaluation of the alternatives against the mission need criteria is presented in Table ES- 1 .

The two alternatives that best meet the mission need are evaluated in detail and compared based on the discriminators of cost, risk, complexity, stakeholder values, and regulatory compliance. This process forms the basis for a recommendation of the alternative that represents best overall value to the government. This process is contained in Sections 4 and 5.

Section 2 describes the two major waste streams (resins and activated metals) that comprise the remote-handled LLW streams for which new disposal capability will be required after FY 2017. The discussion focuses on radiological characteristics, generation rates, and waste packaging and transportation requirements.

Section 3 describes each of the possible remote-handled LLW disposal alternatives and evaluates them against the project mission need. The alternatives are presented in the order in which they were identified in the Mission Need Statement. The alternatives are analyzed against the mission need and those that best meet the mission need are identified based on this assessment. Appendix A provides the details of the DOE Order 413.3B analysis of each of the alternatives involving onsite capabilities. Appendix B provides the details of the same analysis for the alternative of using offsite disposal facilities.

The criteria used to judge which alternatives could best meet the mission need are as follows:

- $\quad$ Capacity to accommodate INL's entire remote-handled LLW inventory. This criterion has two aspects. As a threshold, the alternative must have its 'doors open' to receiving this waste from INL. Second, the alternative should provide management for disposal of INL's entire anticipated remote-handled LLW in terms of waste types, volumes, and concentrations. 
- Availability of alternative, beginning in FY 2018 and continuing through at least FY 2037. This criterion sets the critical time frame within which the mission need must be satisfied.

- $\quad$ Effectiveness in achieving disposal in accordance with DOE Order 435.1. The DOE Radioactive Waste Management Manual implementing DOE Order 435.1 defines disposal as "emplacement of waste in a manner that ensures protection of the public, workers, and the environment with no intent of retrieval and that requires deliberate action to regain access to the waste."

The alternatives to disposal at a new onsite facility and disposal offsite at NNSS are identified to meet the mission need. A new onsite facility is qualified because it could be sited and configured to meet mission need. None of the other alternatives involving use of onsite capabilities meet each criterion of availability, capacity, and effectiveness.

Because use of special performance assessments may be able to qualify all of INL's remote-handled LLW for disposal at NNSS and NNSS is currently available, it was selected for further detailed analysis. All LLW can be accepted and INL would only need to maintain one certification program for waste shipments, minimizing the costs of program administration and oversight. Detailed analysis of costs, risks, and complexity for NNSS is considered the best case representative of the offsite options.

In Section 4, the two alternatives identified as having the best potential for meeting the mission need (i.e., a new onsite disposal facility and disposal offsite at NNSS) are described, evaluated, and compared for purposes of recommending one alternative to implement the project. Each of the two alternatives is assessed in detail using the discriminators of DOE Order 413.3B criteria of risk, cost, complexity, stakeholder values, and regulatory compliance.

Each alternative was assigned a score of 1 or 2 for each criterion, with 1 being assigned to the better alternative for that respective criterion (i.e., a rank of 1 was assigned to the alternative with the lower cost, smaller impact, or least opposition). A total score was obtained by multiplying the weighting factor times the rank for each criterion and then summing all the scores for the individual criteria. The alternative with the lowest total score represents the preferred alternative for providing continued, uninterrupted remote-handled LLW disposal capability for INL operations.

Based on the ranking, the best alternative is development of a new onsite remote-handled LLW disposal facility. Onsite disposal of INL and tenant-generated, remote-handled LLW has the lowest life-cycle cost to DOE, presents less risk to the public because highly radioactive shipments will not be in commerce, and provides the lowest risk of potential impacts on the DOE Office of Nuclear Energy and the Office of Naval Reactors. Therefore, the new onsite disposal facility alternative represents the best value to the government. 
Table ES-1. Summary of evaluation of alternatives against mission need criteria.

Disposal

Alternative

Alternative \#1:

Continued

Disposal at

RWMC

Alternative \#2:

Disposal at the

ICDF

\section{Credible?}

\section{Summary Rationale for Conclusion}

The option to continue disposal at RWMC cannot be implemented because RWMC is planned for closure under INL's cleanup agreement. Continuing operation of the remote-handled LLW vaults while permanently closing the remainder of the facility is not credible given the facility configuration. This option is not available to meet the mission need.

ICDF was not designed for disposal of remote-handled LLW. Disposing of remote-handled LLW at the ICDF would face severe obstacles in terms of obtaining regulatory approvals, conflicting design objectives with the existing cells, and possible conflict with the main mission of the ICDF - consolidation and disposal of all INL CERCLA waste. The likelihood of obtaining all necessary approvals to expand the ICDF waste acceptance criteria to accept remote-handled LLW is extremely low and the risk that this alternative could not be implemented in time to meet the mission need by FY 2018, if ever, is too great to consider this a credible option.

The generator facilities have very limited storage capacity available and there are no plans to expand interim storage capability at the Naval Reactors Facility or the Advanced Test Reactor Complex. Additionally, there are

Alternative \#3:

Interim Storage no other existing or planned facilities onsite to which the remote-handled LLW could be transferred for interim storage without significant capital and operational investment. This option would represent a significant capital expenditure without providing an actual solution to meeting the mission need of providing for permanent disposal of remote-handled LLW generated at INL beyond FY 2017; therefore, is not considered a credible alternative.

Starting with an initial surface exposure rate of 11,000 R/hour for an average Naval Reactors Facility remotehandled LLW container, this waste would have to be stored for over 80 years to decay below the $200 \mathrm{mR} /$ hour

Alternative \#4:

Storage for

Decay criteria for remote-handled LLW. As is the case for the interim storage option, the facilities do not exist onsite for this storage. Providing this storage would require INL to construct or otherwise find new storage capacity at least equivalent to the disposal capacity needed to meet the mission need to support continued generation of remotehandled LLW. Therefore, storage for decay is not considered a credible alternative.

Alternative \#5:

Design,

Construct, and

Operate a New

Onsite

Yes

Remote-Handled

LLW Disposal

Facility $^{\mathrm{a}}$
This alternative was found to be a credible candidate for further analysis because essentially the same activities are already being performed onsite. Risks of implementing this alternative are minimal because the disposal facility design uses current practices. Long-term impacts and stakeholder objections can be mitigated through design, operating, monitoring, and closure standards. The risks of siting, construction, and operation are generally within DOE control. This alternative represents the lowest risk to the publicbecause highly radioactive shipments will not be in commerce.

Costs can be estimated within a reasonable range of certainty and no completely disqualifying characteristics are known. 
Table ES-1. (continued).

This alternative was found to be a credible candidate for further analysis because all of the remote-handled LLW inventory can meet the NNSS waste acceptance criteria (with a special performance assessment). Shipping feasibility has been demonstrated by existing practices of shipping some remote-handled LLW to NNSS.

Alternative \#6: Dispose of All Remote-Handled LLW Offsite at $\mathrm{NNSS}^{\mathrm{b}}$
Yes Additional risks and costs versus the onsite alternative exist but do not appear insurmountable. A project would be needed to acquire new shipping cask systems, but an acceptable cask appears to exist (at least in the planning and certification stage).

The risk of single-point failure if NNSS is unable to receive waste would have to be accepted or mitigated. Costs can be estimated within a reasonable range of certainty; however, future disposal costs are uncertain because the volumes of waste from other DOE facilities that are disposed of at NNSS will affect the unit cost basis for disposal.

No completely disqualifying characteristics are known.
Alternative \#7:

Privatization of

INL Remote-

Handled LLW

Disposal
The complex process of constructing an onsite, privately-owned and operated facility or speculating that an offsite commercial facility will be placed in operation in time to support uninterrupted INL and tenant-generated remote-handled LLW disposal would represent severe programmatic risk with no discernable advantage over No known credible options. If such capability did not come to fruition, the resulting impacts to both nuclear energy and naval reactor missions would be substantial. This option poses too high a risk of not meeting the mission need of providing for permanent disposal of remote-handled LLW generated at INL beyond FY 2017 and is not considered a credible alternative.

\section{Alternative \#8: No Action}

Given the low storage capacity for these waste streams at generators' sites, this alternative would result in a cessation of operations on vital national missions in just a few years. Therefore, considering the long-term DOE missions at INL, the no action alternative is not a credible alternative. The no action alternative will still be carried forward to the National Environmental Policy Act evaluation.

\footnotetext{
CERCLA = Comprehensive Environmental Response, Compensation, and Liability Act $\quad$ INL = Idaho National Laboratory DOE $=$ Department of Energy

$\mathrm{FY}=$ fiscal year

LLW = low-level waste

NNSS $=$ Nevada National Security Site

ICDF = Idaho CERCLA Disposal Facility

RWMC = Radioactive Waste Management Complex

a. Appendix A of this report provides analysis detail on selection of the new onsite facility as the best onsite alternative.

b. Appendix B of this report provides analysis detail of eight candidate offsite facilities and the selection of NNSS as the best offsite alternative.
} 
Section 5 is a summary of the analysis and recommendations. The onsite disposal alternative (\#5) was ranked higher than the alternative for offsite disposal at NNSS in all categories except Idaho stakeholder opposition, having the lowest cost, lowest risk, and being the least complex to implement. The alternative of shipping offsite to NNSS (\#6) involves significant challenges. It is the more complex and, therefore, riskier alternative, requiring changes to infrastructure at multiple locations and acquisitions of material that will require third party certification. Second, the increased number of offsite shipments from the Naval Reactors Facility compared to onsite shipments would create significant operational constraints and burdens on the Naval Reactors Facility and potentially conflict with the Naval Reactors Facility's primary mission to support the Naval Nuclear Propulsion Program. Finally, this alternative does not offer a guaranteed solution because reliance on special performance assessments for regular waste shipments has significant risk that individual shipments may be sufficiently out of the norm to be unable to qualify for disposal.

Cumulative project costs indicate that the life-cycle costs of offsite disposal (Alternative 6) are significantly higher than the costs of disposal in a new onsite facility (Alternative 5). These costs are presented in Figure ES-1. Appendix $\mathrm{C}$ includes additional cost and schedule information for the two alternatives.

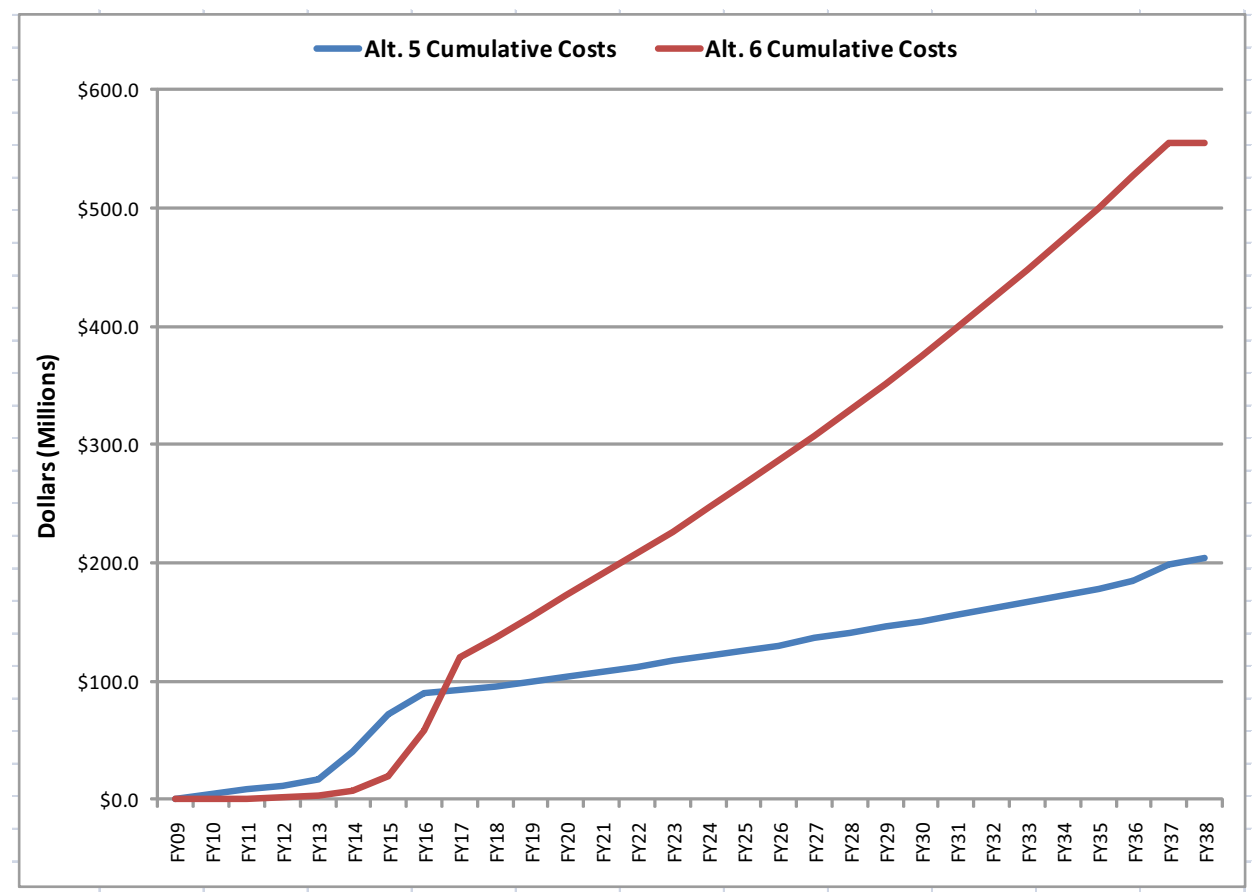

Figure ES-1. Cumulative project costs by alternative.

The onsite disposal alternative involves lower risk because it presents no offsite transportation or disposal considerations. In the recommended alternative, the risks are all, at least to some degree, under DOE control. Procurement of cask systems for offsite transportation is eliminated, decreasing cost and schedule risk. Dependence on the cooperation of third parties, such as disposal site operators or states other than Idaho, is reduced to the absolute minimum. The onsite disposal 
alternative does involve increased Idaho stakeholder concerns as compared to offsite disposal. Stakeholder considerations will be addressed as part of the National Environmental Policy Act process, which will provide opportunity for comment on DOE's proposed action.

Based on the ranking, the best alternative is development of a new onsite remote-handled LLW disposal facility (Alternative 5). Onsite disposal of INL and tenant-generated, remote-handled LLW has the lowest life-cycle cost to DOE, represents the lowest risk to the public because highly radioactive shipments will not be in commerce, and provides the lowest risk of potential impacts on the DOE Office of Nuclear Energy and the Office of Naval Reactors. Therefore, the new onsite disposal facility alternative represents the best value to the government. 


\section{CONTENTS}

ABSTRACT

EXECUTIVE SUMMARY $\mathrm{v}$

ACRONYMS xvii

1. INTRODUCTION $1-1$

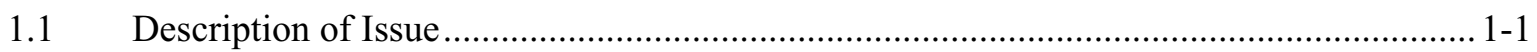

1.2 Identification of Alternatives for Analysis ................................................................ 1-2

1.3 Criteria and Approach used for Alternatives Analysis............................................... 1-2

$1.4 \quad$ General Assumptions for Alternatives Analysis ........................................................... 1-3

2. IDAHO NATIONAL LABORATORY REMOTE-HANDLED LOW-LEVEL WASTE TYPES AND VOLUME EXPECTED THROUGH 2037 ...................................................... 2-1

2.1 Remote-Handled Low-Level Waste Streams and Generation Rates............................... 2-1

2.2 General Characteristics of Remote-Handled Low-Level Waste Packaging.......................2-2

3. SELECTION OF DISPOSAL ALTERNATIVES FOR EVALUATION .................................... 3-1

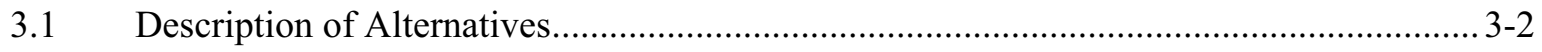

3.1.1 Alternative 1-Continued Disposal at RWMC ......................................... 3-2

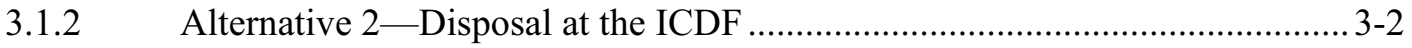

3.1.3 Alternative 3 - Interim Storage .................................................................. 3-4

3.1.4 Alternative 4-Storage for Decay .......................................................... 3-4

3.1.5 Alternative 5-Development of an Onsite Remote-Handled LLW

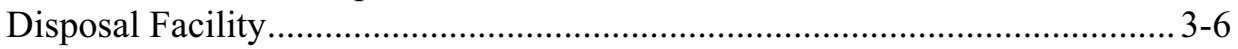

3.1.6 Alternative 6-Offsite Disposal (Multiple Locations)................................. 3-6

3.1.7 Alternative 7-Privatization of Remote-Handled LLW Disposal .................... 3-9

3.1.8 Alternative 8-No Action .................................................................... 3-10

3.2 Selection of Alternatives for Further Evaluation..................................................... 3-10

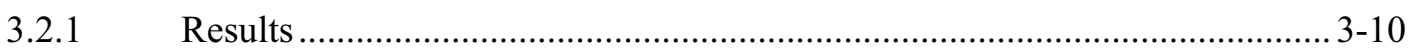

4. REMOTE-HANDLED LOW-LEVEL WASTE DISPOSAL ALTERNATIVE

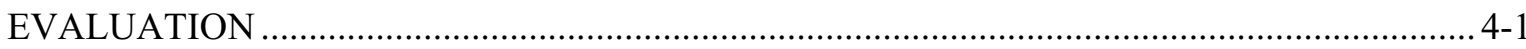

4.1 Detailed Analysis of Alternative 5: A New Onsite Disposal Facility for INL's

Remote-Handled Low-Level Waste

4.1.1 Assumptions and Strategies ............................................................... 4

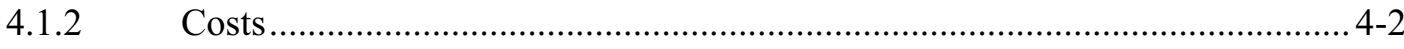




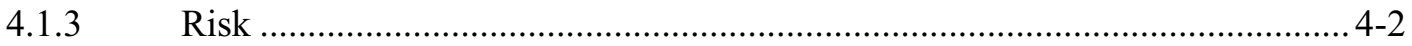

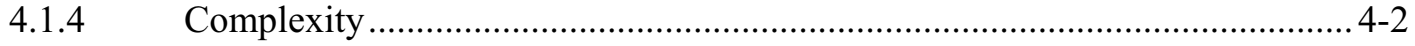

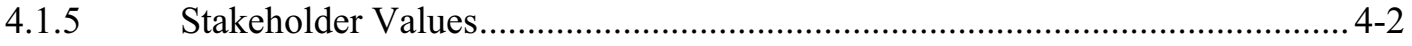

4.1.6 Regulatory Compliance .......................................................................... 4-3

4.2 Detailed Analysis of Alternative 6: Offsite Disposal of Remote-Handled

Low-Level Waste at the Nevada National Security Site ................................................... 4-3

4.2.1 Assumptions and Strategies .................................................................... 4-3

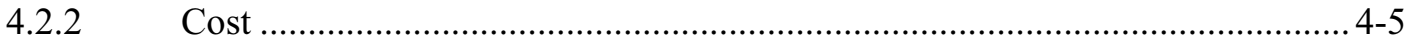

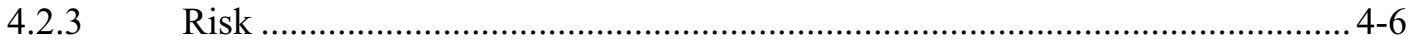

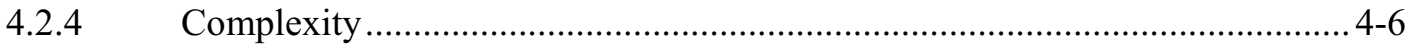

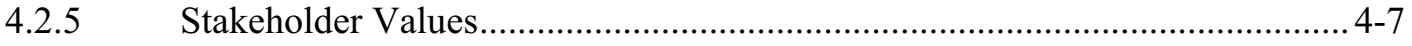

4.2.6 Regulatory Compliance................................................................................. $4-7$

4.3 Comparison of Final Alternatives …......................................................................... 4-7

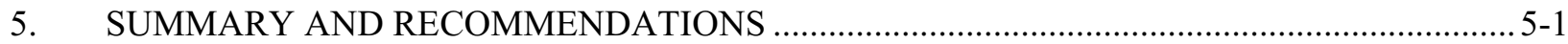

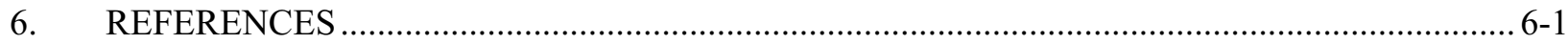

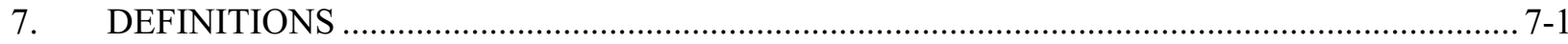

\section{APPENDIXES}

Appendix A, Details of Evaluation of Onsite Alternatives for Remote-Handled Low-Level Waste Disposal...

Appendix B, Details of Evaluation of Offsite Alternatives for Remote-Handled Low-Level Waste Disposal

Appendix C, Assumptions, Schedules, and Costs C-1

\section{FIGURES}

ES-1. Cumulative project costs by alternative $\mathrm{X}$

3-1. Onsite facilities of interest at the Idaho National Laboratory ................................................. 3-1

3-2. Aerial view of the Radioactive Waste Management Complex vault operation ...........................3-2

3-3. Idaho CERCLA Disposal Facility located at the Idaho National Laboratory …...........................3-3

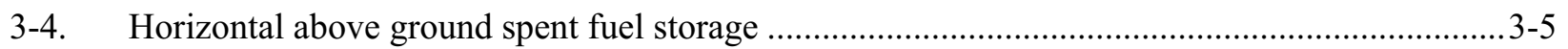

3-5. Close up view of horizontal above ground spent fuel storage …............................................. 3-5

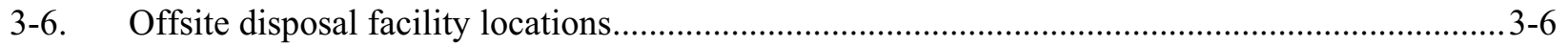

5-1. Annual project costs by disposal alternative ....................................................................... $5-2$ 
5-2. Cumulative comparison costs by disposal alternative

\section{TABLES}

ES-1. Summary of evaluation of alternatives against mission need criteria .........................................viii

2-1. Remote-handled low-level waste resins and activated metals waste streams ...........................2-1

2-2. Waste anticipated to be generated for each remote-handled low-level waste at the

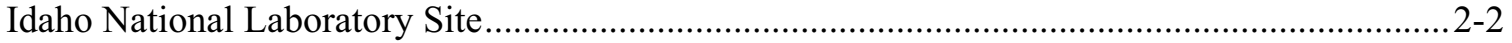

3-1. Summary of initial evaluation of remote-handled LLW disposal alternatives .........................3-12

4-1. Ranking of alternatives for Idaho National Laboratory remote-handled low-level waste

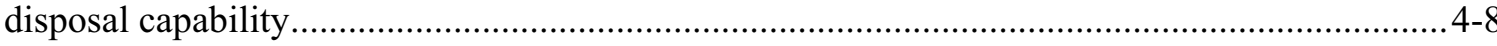




\section{ACRONYMS}

ATR

CD

CERCLA

DOE

DOE-ID

EA

EMWMF

FY

ICDF

INL

LLW

MFC

NEPA

NNSA

NNSS

NRC

NRF

NTS

$\mathrm{NuPac}$

ROD

RWMC

SDA

WAC

WCS
Advanced Test Reactor

Critical Decision

Comprehensive Environmental Response, Compensation and Liability Act

U.S. Department of Energy

U.S. Department of Energy Idaho Operations Office

environmental assessment

Environmental Management Waste Management Facility

fiscal year

Idaho CERCLA Disposal Facility

Idaho National Laboratory

low-level waste

Materials and Fuels Complex

National Environmental Policy Act

National Nuclear Security Administration

Nevada National Security Site

Nuclear Regulatory Commission

Naval Reactors Facility

Nevada Test Site

Nuclear Packaging

Record of Decision

Radioactive Waste Management Complex

Subsurface Disposal Area

waste acceptance criteria

Waste Control Specialists 
xviii 


\section{Remote-Handled Low-Level Waste Disposal Project Alternatives Analysis}

\section{INTRODUCTION}

This report presents an analysis of the alternatives for disposal of remote-handled low-level waste (LLW) generated by the Idaho National Laboratory (INL), U.S. Department of Energy's (DOE's) Office of Nuclear Energy and its tenant, and the Office of Naval Reactors. A systematic approach has been used to identify disposal needs, alternatives for meeting those needs, and to develop the associated costs, schedules, and risks in sufficient detail to a make a valid comparison of the alternatives. This report has been prepared to support project planning under DOE Order 413.3B, "Program and Project Management for Acquisition of Capital Assets."

\subsection{Description of Issue}

The INL routinely generates remote-handled LLW from facility operations and decontamination and decommissioning of inactive facilities. Historically, the INL has disposed of its remote-handled LLW in the Subsurface Disposal Area (SDA) of the Radioactive Waste Management Complex (RWMC). This facility includes disposal pits and concrete vaults. However, this existing disposal facility is planned to be closed under INL's environmental management contract.

On July 1, 2009, DOE approved a Mission Need Statement for the INL Remote-Handled LLW Disposal Project:

The INL will develop replacement remote-handled low-level waste disposal capability by the end of Fiscal Year 2015 to support cost-effective, efficient operations in support of INL's nuclear energy mission and the Naval Nuclear Propulsion Program. Such disposal capability is required to enhance ongoing departmental and national mission-based research, defense, and energy programs.

The mission need date was later extended to Fiscal Year (FY) 2017 based on a 2-year extension of availability of the existing disposal vaults in the SDA.

This alternatives analysis was conducted to implement project planning requirements of DOE Order 413.3B for conceptual design. The objective of this analysis is to identify an alternative for future remote-handled LLW management that will form the basis for the conceptual design to be submitted for Critical Decision (CD)-1 approval. A systematic approach was employed to achieve this objective, which involved defining future remote-handled LLW disposal needs, evaluating disposal alternatives, and recommending an alternative.

The DOE manual for implementing DOE Order 435.1, Radioactive Waste Management, provides DOE's policy for disposing of radioactive waste, including LLW:

DOE radioactive waste shall be treated, stored, and in the case of low-level waste, disposed of at the site where the waste is generated, if practical; or at another DOE facility. If DOE capabilities are not practical or cost-effective, exemptions may be approved to allow use of non-DOE facilities for the storage, treatment, or disposal of DOE radioactive waste. 
Recent DOE guidance addressing LLW and mixed low-level waste has reinforced this policy, noting that, if feasible, disposal should occur at the facility where LLW is generated. If onsite disposal is not feasible, use of a federal disposal facility is preferred, although a commercial facility could be used on an exemption basis when it is demonstrated to be compliant, cost-effective, and in the best interest of DOE. As stated in the guidance (DOE 2009b):

Under the existing order, where feasible, LLW/mixed low-level waste should be disposed at the site where it is generated provided the site has an appropriate and approved facility and the waste meets its waste acceptance criteria. There may be circumstances, however, where site cleanup goals and obligations make it infeasible to utilize onsite disposal. When onsite disposal is not feasible and wastes must be shipped offsite, DOE policy identifies a preference for use of a Federal disposal facility. However, DOE Order 435.1 specifically provides for the use of a commercial disposal facility, on an exemption basis, when it is demonstrated to be compliant, cost.effective, and in DOE's best interest.

This document includes the analysis that is needed to implement DOE policy. It addresses remote-handled LLW disposal needs of INL and its tenant after October 1, 2017. It does not include mixed low-level waste, which DOE has determined will not be disposed of onsite (DOE 2000). The remote-handled LLW identified for planning purposes includes waste expected to be generated from ongoing operations for 20 years, in addition to a contingency to account for future missions.

\subsection{Identification of Alternatives for Analysis}

A range of possible alternatives for INL remote-handled LLW disposal were identified in the Mission Need Statement for the project (DOE 2009a), including alternatives that would utilize existing assets. Since then, no new alternatives have been identified. These alternatives are listed as follows:

1. Continued disposal at RWMC

2. Disposal at the Idaho Comprehensive Environmental Response, Compensation and Liability Act (CERCLA) Disposal Facility (ICDF)

3. Interim storage

4. Storage for decay

5. Development of an onsite remote-handled LLW disposal facility

6. Offsite remote-handled LLW disposal (multiple locations)

7. Privatization of remote-handled LLW disposal

8. No action.

\subsection{Criteria and Approach used for Alternatives Analysis}

A systematic approach is used to assess the remote-handled LLW management alternatives and accomplish the objectives of this analysis. The alternatives are evaluated and compared in Section 4 . The waste expected to be generated and related transportation considerations are identified so that the waste shipments could be evaluated against the waste acceptance criteria (WAC) of DOE and commercial 
disposal facility alternatives. The alternatives are reviewed for their potential to fulfill the mission need for replacement disposal capability of all INL Site remote-handled LLW through at least the year 2037. The alternatives that best meet the mission need are further evaluated and compared based on the discriminators of cost, risk, complexity, stakeholder values, and regulatory compliance. This process forms the basis for a recommendation of the alternative which represents the best overall value to the government.

\subsection{General Assumptions for Alternatives Analysis}

The following assumptions have been established as the basis for the alternatives analysis. Assumptions specific to a particular alternative are included in those sections of this report where that alternative is presented.

- Except where specifically noted, DOE facilities are regulated under DOE Order 435.1. A disposal authorization for the facility is issued based upon an approved performance assessment and composite analysis. It is assumed that compliance with DOE Order 435.1 would be required for alternatives involving use of DOE facilities.

- Commercial or private facilities are regulated by the Nuclear Regulatory Commission (NRC) or under a state-authorized program which issues licenses for disposal of LLW. It is assumed that current license requirements for existing commercial or private facility alternatives would apply.

- Except where specifically noted, any of the alternatives could be planned and scheduled to meet the mission need start date. It is assumed that construction or modification of facilities or acquisition of transport casks for onsite or offsite disposal of remote-handled LLW could be accomplished to support disposal in FY 2018.

- Potential impacts on humans and the environment for disposal of INL remote-handled LLW will be assessed in a National Environmental Policy Act (NEPA) environmental assessment (EA). 


\section{IDAHO NATIONAL LABORATORY REMOTE-HANDLED LOW-LEVEL WASTE TYPES AND VOLUME EXPECTED THROUGH 2037}

This section describes the two major waste streams, resins, and activated metals that comprise the remote-handled LLW streams for which new disposal capability will be required after FY 2017. The discussion focuses on radiological characteristics, generation rates, and waste packaging and transportation requirements.

\subsection{Remote-Handled Low-Level Waste Streams and Generation Rates}

INL produces two types of remote-handled LLW that will require disposal capability after FY 2017: resins from the Naval Reactors Facility (NRF) and Advanced Test Reactor (ATR) and activated metals from NRF, ATR, and the Materials and Fuels Complex (MFC). The remote-handled resin waste stream and activated metals waste streams are generated by multiple facilities. Table 2-1 describes these waste streams by generator ${ }^{\mathrm{a}}$.

Table 2-1. Remote-handled low-level waste resins and activated metals waste streams.

\section{Waste}

Stream

Generator

Description

ATR produces ion exchange resins from pool and reactor operations.

INL Prior to September 30, 2008, the waste was disposed of in the

ATR Complex RWMC pit. Since closure of the RWMC pit, the waste is being

Resins disposed of offsite at the Nevada National Security Site (NNSS).

NRF

NRF produces ion exchange resins from pool operations. Currently, the waste is disposed of in the RWMC vaults in liners transported using a 55-ton cask.

ATR produces activated metals during reactor core change-out operations approximately every 8 years. Since there is only storage capacity for one cycle of core change-out components at the ATR

INL Complex, these components only have an approximate 8-year decay ATR Complex time before they must be cycled out for disposal to accommodate the next cycle. Previous disposal has been at RWMC using a cask that is

Activated Metals no longer in use. It is assumed a suitable replacement
available for transportation and disposal operations.

$\mathrm{NRF}$

NRF produces activated metals during routine operations. Currently, waste is disposed of in the RWMC vaults in 55-ton scrap cask liners.

MFC will generate activated metals during waste segregation

INL MFC operations for waste removed from the storage at the Radioactive Scrap Waste Facility. It is assumed a suitable cask would be available for transportation and disposal operations.

\footnotetext{
a Discussions referencing "remote-handled resin waste stream" and "remote-handled activated metals waste streams" refer to the waste streams that contain waste resins and activated metals as their primary component, respectively. Each of these waste streams may contain non-resin or non-activated metals waste components within the limits of the respective waste profiles. References to "resins" or "activated metals" without specifying waste stream indicate discussion of the waste components themselves and not necessarily the bulk waste stream in which they are contained. References to "remote-handled LLW" without further specification will generally refer to the target waste streams of this analysis, but may, depending on context, include other historical waste streams or potential new waste streams for future missions or waste processing.
} 
The volumes and activity of remote-handled LLW anticipated to be generated through the year 2037 have been forecast. Table 2-2 provides rates of waste generation by location. The maximum contact exposure rate expected to be encountered for remote-handled activated metals LLW streams from NRF, ATR, MFC, and other INL programs is $30,000 \mathrm{R} /$ hour. The expected maximum contact exposure rates for remote-handled resin LLW streams from ATR and NRF are $2 \mathrm{R} /$ hour and $15 \mathrm{R} /$ hour, respectively.

Table 2-2. Waste anticipated to be generated for each remote-handled low-level waste at the Idaho National Laboratory Site.

\begin{tabular}{|c|c|c|c|c|c|}
\hline $\begin{array}{c}\text { Waste } \\
\text { Streams }\end{array}$ & Location & Generation & Period & $\begin{array}{l}\text { Current } \\
\text { Transport }\end{array}$ & $\begin{array}{c}\text { Average Annual } \\
\text { Waste Package } \\
\text { Volume } \\
\left(\mathrm{m}^{3} / \text { year }\right)\end{array}$ \\
\hline \multirow{2}{*}{ Resins } & ATR Complex & Continuous & $\begin{array}{l}\text { Yearly } \\
(2037)\end{array}$ & $\begin{array}{c}\text { NuPac } \\
14-210 \mathrm{~L} \\
\text { (shielding only) }\end{array}$ & $36^{\mathrm{a}}$ \\
\hline & $\mathrm{NRF}$ & Continuous & $\begin{array}{l}\text { Yearly } \\
(2037)\end{array}$ & $\begin{array}{c}\text { 55-ton cask } \\
\text { (shielding only) }\end{array}$ & 8 \\
\hline \multirow{3}{*}{$\begin{array}{c}\text { Activated } \\
\text { Metals }\end{array}$} & ATR Complex & $\begin{array}{c}\text { Batch } \\
\text { (core internal } \\
\text { change out) }\end{array}$ & $\begin{array}{c}\sim \text { Every } 8 \text { years } \\
\quad(2037)\end{array}$ & None identified & 3 \\
\hline & $\mathrm{NRF}$ & Continuous & $\begin{array}{l}\text { Yearly } \\
(2037)\end{array}$ & 55-ton scrap cask & $35^{\mathrm{b}}$ \\
\hline & $\begin{array}{l}\text { MFC and other } \\
\text { INL programs }\end{array}$ & Continuous & $\begin{array}{l}\text { Yearly } \\
(2037)\end{array}$ & None identified & 2 \\
\hline
\end{tabular}

a. The ATR remote-handled LLW resin waste stream that had previously been disposed of in pits at RWMC is now shipped offsite to NNSS due to closure of the pits. If the alternative of onsite disposal was selected, it is assumed that it would be more cost effective to resume disposal of these resins onsite. Therefore, this waste stream is also included in the planned disposal volume. Disposal at NNSS would still be retained as a contingent option for the ATR resins.

b. NRF waste generation rates are based on current plans. In any proposed recapitalization project to replace the aging NRF Expended Core Facility, NRF waste generation rates may increase in order to accommodate facility-specific fuel processing activities and waste generated during decommissioning of the current facility.

\subsection{General Characteristics of Remote-Handled Low-Level Waste Packaging}

Remote-handled LLW ion-exchange resins are generated from pool and reactor operations at ATR and from pool operations at NRF. Resins from ATR are packaged in liners and transferred in a Nuclear Packaging (NuPac) 14-210L container for disposal. The INL's NuPac 14-210L cask currently is used for transport of ATR ion-exchange resins to NNSS for disposal. This cask is certified as a U.S. Department of Transportation Specification 7A package for low specific activity resins. The cask fully satisfies U.S. Department of Transportation requirements as a Type A package. ATR ion-exchange resin is generated about four to six times per year from reactor loop and reactor ion-exchange systems. The generation rate depends on reactor operations and also varies during the years when core internal change outs are performed. ATR operations generally attempt to fill the cask volume with resins from both resin sources to efficiently use the cask volume. 
NRF resins have similar radionuclide profiles to NRF activated metals, though at lower activity levels. These resins are currently disposed of onsite in the same manner as NRF activated metals. NRF resins are currently packaged in liners and transported in the 55-ton scrap cask to the SDA facility for disposal in vaults. Remote-handled LLW activated metals from NRF are currently packaged into 55-ton cask liners of different design than the resin liners, though of similar volume. The NRF LLW activated metals liners are shipped in the same 55-ton scrap cask that is used for transporting NRF resins onsite. The 55-ton scrap cask could continue to be used for onsite shipments but cannot be used for transport on public highways. For offsite shipments from NRF, a commercial cask that is sized for either highway or rail transport (depending on the receiving facility's transportation infrastructure) would be required.

It is assumed that a commercial cask would be acquired for shipments of activated metal waste streams planned to be generated from ATR and MFC. A transport cask would be required for shipments of these waste streams under both the onsite and offsite disposal scenarios.

If the onsite alternative is selected, the NuPac 14-210L cask currently in use would continue to be used for onsite shipment of ATR resins. The 55-ton scrap cask could continue to be used for NRF activated metals and resins. An additional cask would be needed for ATR and MFC activated metals. It may be possible to use an existing cask that is currently available onsite. If not, a new cask would be purchased, but it would not have to be certified for transportation on public roads. This cask would be procured as part of the project for implementation of the onsite alternative.

If the offsite alternative is selected, the 55-ton scrap cask for NRF activated metals would have to be replaced by multiple smaller casks certified for transportation on public roads. An additional cask, also certified for transportation on public roads, would be required for ATR and MFC activated metals. Two different cask designs would be required, each requiring on-road certification. The NuPac 14-210L cask could continue to be used for offsite shipment of ATR resins, as this cask is already certified for transport on public roads. 
2-4 


\section{SELECTION OF DISPOSAL ALTERNATIVES FOR EVALUATION}

This section describes each of the possible remote-handled LLW disposal alternatives and evaluates them against the project mission need. The alternatives are presented in the order in which they were identified in the Mission Need Statement. The alternatives that best meet the mission need are identified based on this assessment. A map of the INL site and onsite facilities of interest is provided in Figure 3-1. Appendix A provides the details of the analysis of each of the alternatives involving onsite capabilities. Appendix B provides the details of the analysis of the alternatives using offsite disposal facilities.

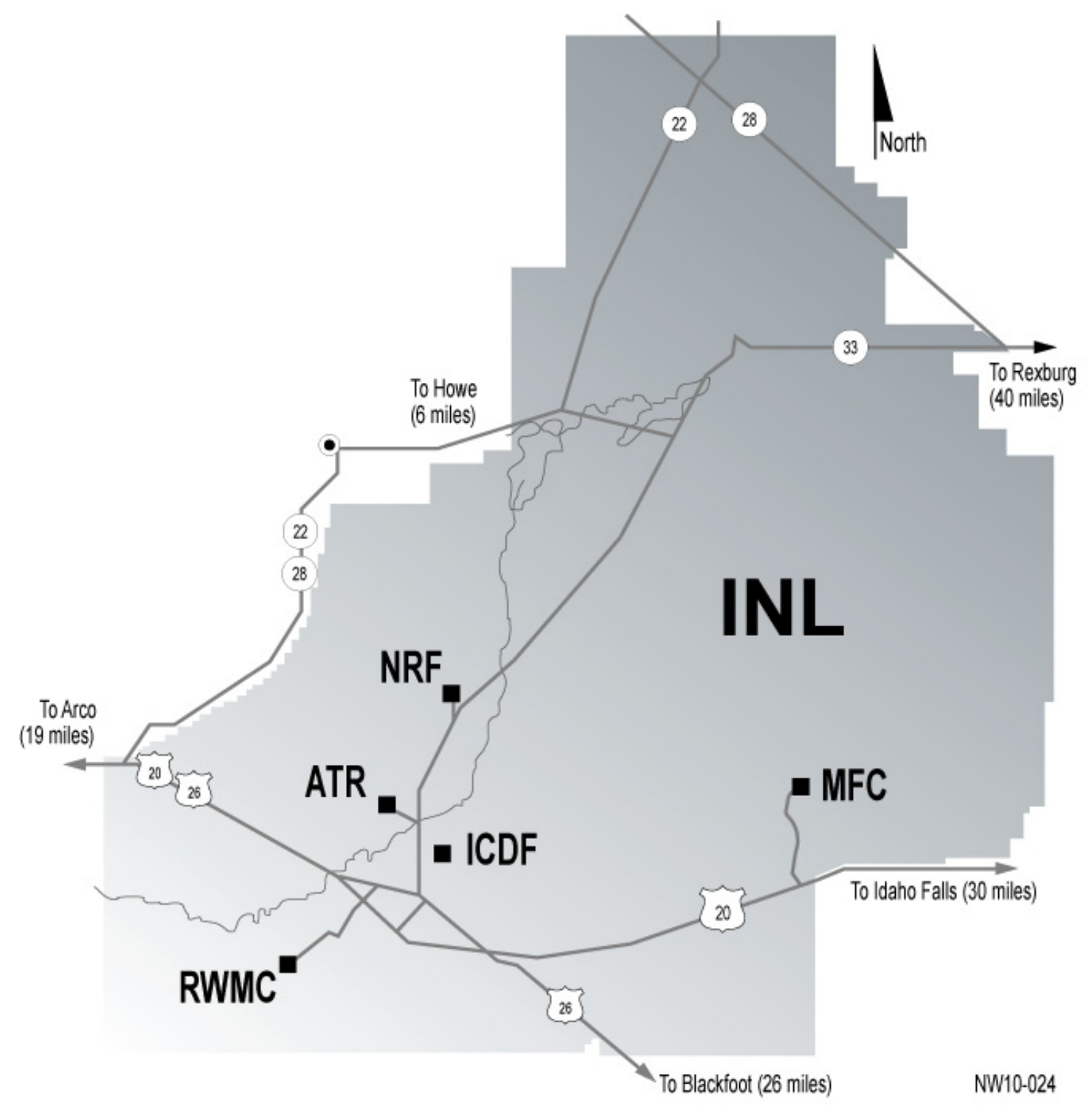

Figure 3-1. Onsite facilities of interest at the Idaho National Laboratory. 


\subsection{Description of Alternatives}

\subsubsection{Alternative 1-Continued Disposal at RWMC}

The majority of INL-generated remote-handled LLW has historically been disposed of in the SDA at the RWMC (Figure 3-2). This alternative would continue this waste disposition practice. As of the end of FY 2009, there were 81 unused vaults available for disposal of remote-handled LLW at the RWMC. This would provide sufficient disposal capacity for NRF waste until approximately 2019 at the current generation rate.

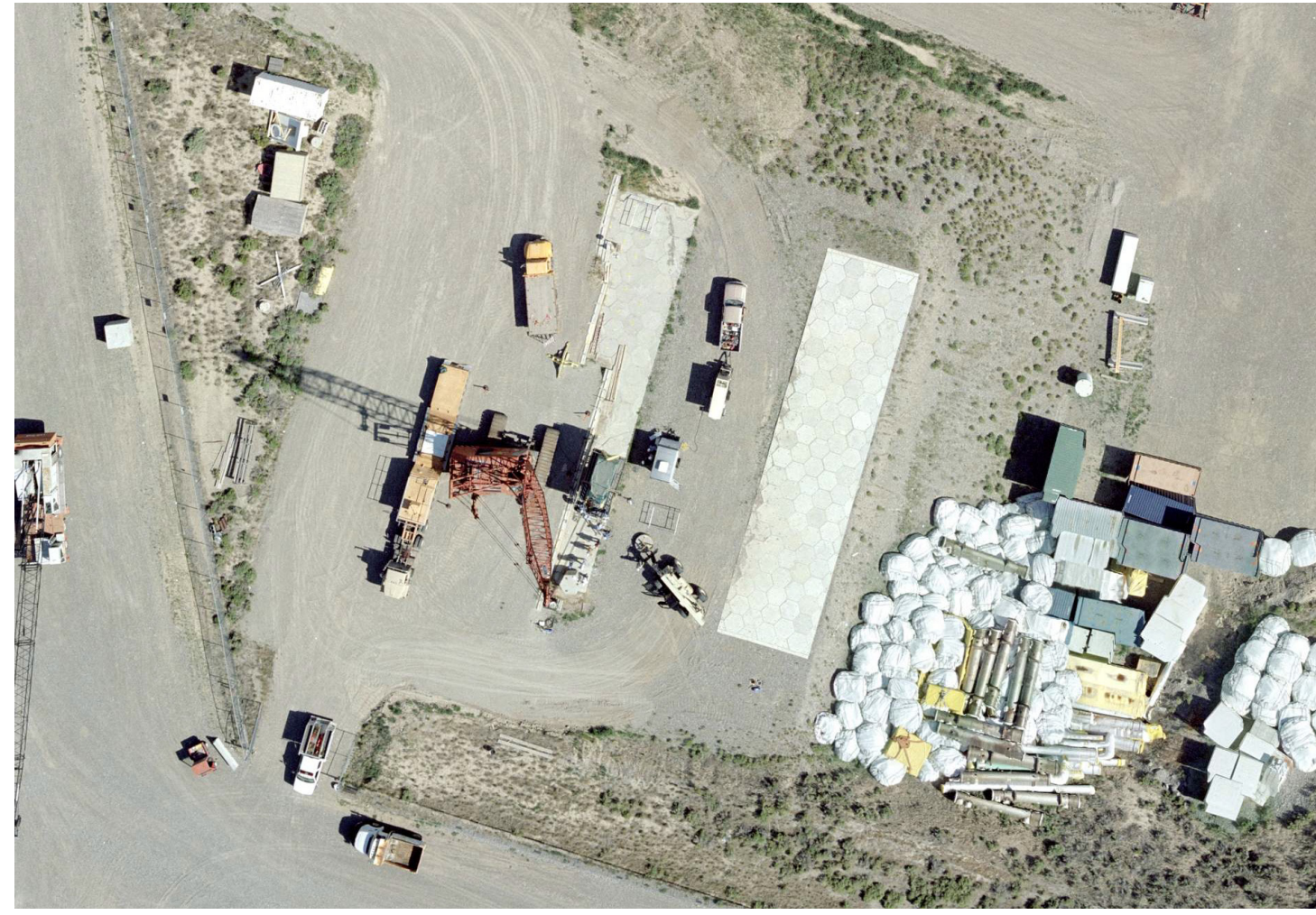

Figure 3-2. Aerial view of the Radioactive Waste Management Complex vault operation.

The SDA is undergoing permanent closure pursuant to a Record of Decision (ROD) (DOE-ID 2008) issued under the INL's Federal Facility Agreement/Consent Order for cleanup of the site (DOE-ID 1991). Subject to the provisions of the ROD, the DOE Office of Environmental Management contractor will implement the SDA closure in a manner that supports operation of the remote-handled LLW disposal vaults through the end of FY 2017, if possible. Continued operation of the SDA for 20 years after 2017 would effectively implement the no action clean-up alternative for 20 years, and this is not acceptable. As identified in the proposed plan for cleanup at the RWMC (DOE-ID 2007a), the no action alternative was not selected because it failed to meet threshold cleanup criteria of protecting human health and the environment and complying with environmental requirements.

\subsubsection{Alternative 2-Disposal at the ICDF}

DOE authorized a remedial design/remedial action under CERCLA for the Idaho Nuclear Technology and Engineering Center in accordance with the Waste Area Group 3, Operable Unit 3-13 ROD (DOE-ID 1999). The Operable Unit 3-13 ROD requires removal and onsite disposal of some of the 
CERCLA remediation waste generated within the boundaries of INL. The ICDF Complex was constructed immediately south of the Idaho Nuclear Technology and Engineering Center to meet this requirement. The landfill can currently receive any CERCLA-generated waste from outside Waste Area Group 3 that meets the land disposal restriction requirements delineated in the ICDF Complex WAC (DOE-ID 2007b). ICDF is required under CERCLA to meet the substantive requirements of the Resource Conservation Recovery Act (42 USC § 6901 et seq.). Therefore, the facility is subject to the substantive requirements for a hazardous waste disposal facility while also being regulated under DOE Order 435.1 for radioactive waste disposal.

The ICDF, Figure 3-3, is currently limited to receipt of only CERCLA waste and it has an assumed closure date in 2018. It was not designed for disposal of remote-handled LLW. An extension to operations and a change to the ICDF WAC to accept non-CERCLA generated waste streams from INL and NRF operations in the existing ICDF landfill cells would require a design modification, a new performance assessment, and approval of the DOE Office of Nuclear Energy, DOE Office of Environmental Management, Department of Energy Idaho Operations Office (DOE-ID), the State of Idaho, and the Environmental Protection Agency to amend the CERCLA ROD establishing ICDF, as the existing ROD limits the ICDF to waste generated from INL CERCLA activities only (DOE-ID 1999).

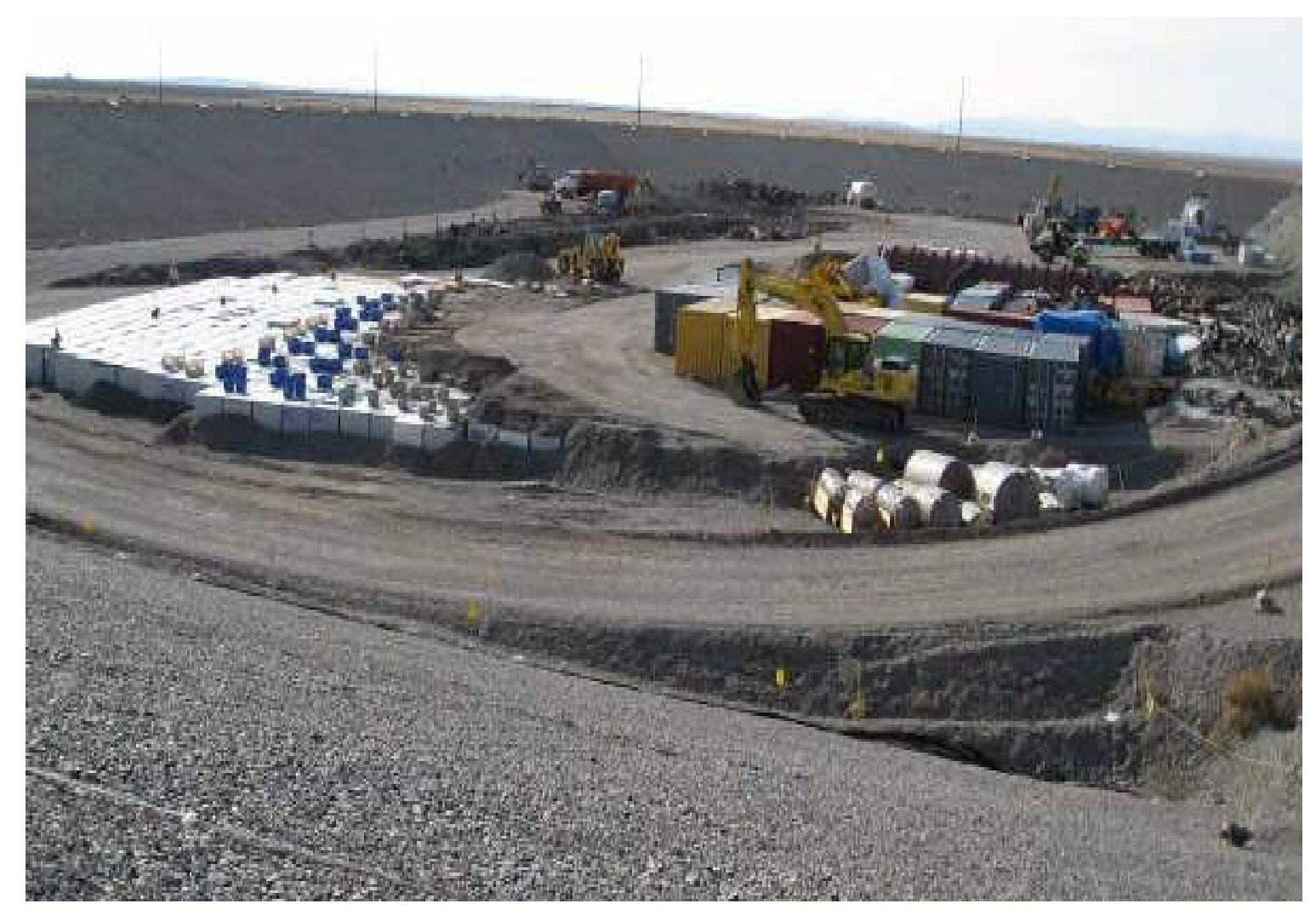

Figure 3-3. Idaho CERCLA Disposal Facility located at the Idaho National Laboratory.

In theory, if regulatory hurdles were cleared, remote-handled LLW generated beyond FY 2017 could be disposed of at ICDF following closure of the SDA. ICDF has two lined disposal cells, but does not include vaults for disposal of remote-handled waste. Management of remote-handled LLW in the existing ICDF landfill cells would likely require construction of disposal vaults similar to those currently used in the SDA. Additional infrastructure changes and adoption of appropriate operating procedures would also be required to support receipt of casks of remote-handled LLW from onsite generators. 
The CERCLA cell design does not meet the requirements of the preferred design for remote-handled LLW disposal, but does not preclude construction of an adjacent facility for remote-handled LLW.

\subsubsection{Alternative 3-Interim Storage}

This alternative is defined as storage of remote-handled LLW either at the generator facilities or at another acceptable, safe location until the disposal capability discussed in the Mission Need Statement is available. NRF currently stores its remote-handled LLW within the canals and fuel storage pool of the facility until it is transferred to RWMC for disposal. Current operational schedules at NRF provide for a maximum interim storage capacity of approximately 2 years of waste generation. Exceeding this interim storage capacity would significantly impact fuel-handling activities at NRF until such time as the remotehandled waste could be transferred to another facility for continued interim storage or disposal.

ATR also has limited interim storage capacity. The current interim canal storage for activated metals is full. Waste must be dispositioned from this location prior to the next core internals changeout planned in 2015.

This alternative would represent a significant capital expenditure to provide a commercial-type, outdoor, interim storage facility as shown in Figures 3-4 and 3-5 (see Appendix A) without providing a solution to the permanent disposal of remote-handled LLW generated at INL beyond FY 2017. If the remote-handled LLW were stored above ground, the high radiation readings would require a minimum of 5 -ft thickness of steel-reinforced concrete for shielding. The above-ground structure would also require significant steel reinforcement to meet applicable seismic requirements. The soil provides shielding and structural stability for the planned below ground disposal. The material costs of the precast concrete vaults (below ground) are estimated to cost $\$ 8,000$ per vault. In comparison, if the same vault dimensions were constructed for above ground storage using steel reinforced concrete with required 5 -ft thick concrete to provide shielding, the estimated material cost per vault is $\$ 31,500$. The above ground storage would be configured similar to existing spent fuel storage facilities, as shown in the following figures.

Additional considerations and potential barriers for above ground storage include extensive seismic analysis and nuclear safety requirements.

\subsubsection{Alternative 4-Storage for Decay}

This alternative is defined as storage of remote-handled LLW either at the generator facilities or at other acceptable, safe locations for sufficient time that its radioactive source term would decay to activity levels that would be acceptable for less restrictive disposal options such as those available for contact-handled LLW. Approximately half of the remote-handled LLW inventory is activated metals. This waste type is anticipated to present the most challenging dose and waste characteristic issues relative to transport and disposal.

Theoretically, with the practice of storage for decay, remote-handled LLW could be stored to allow the radioactivity to decay to levels where less restrictive WAC could be met and shipping requirements greatly simplified (e.g., use of Type A casks rather than Type B casks). However, the half-lives of some of the isotopes of interest make it impractical to store this waste for the required decay period. For example, Ni-63 is a significant contributor to the NRF activated metals waste stream and has a 101 year half-life (Collé et al. 2008). Another example is the isotope that contributes to the majority of the gamma exposure, Co-60. While this isotope has a relatively short half-life of 5.27 years (Unterweger 2002), the decay storage time is significant given the initial exposure rates of 30,000 and $11,000 \mathrm{R} / \mathrm{hour}$ for the maximum and average NRF remote-handled LLW containers, respectively. 


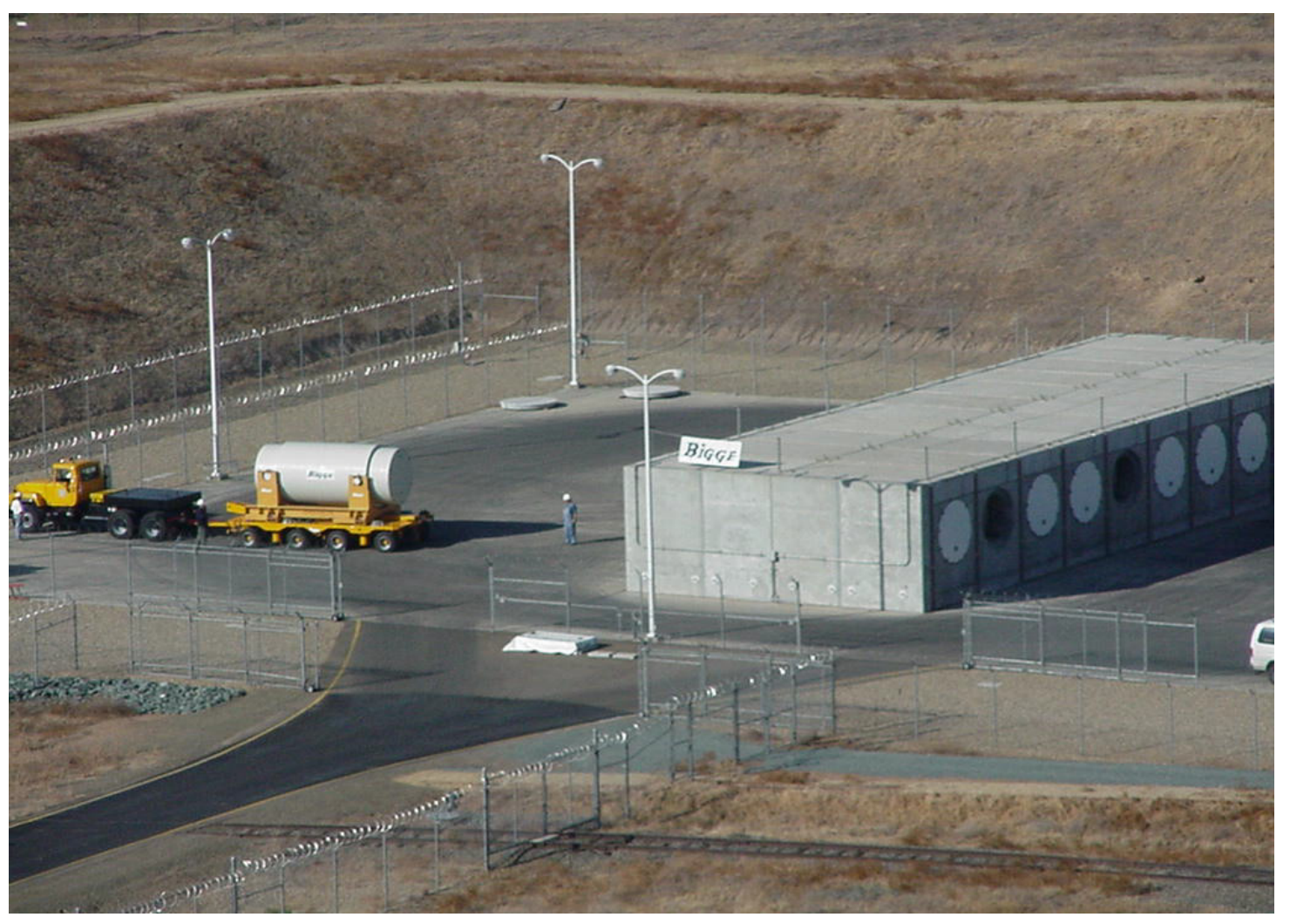

Figure 3-4. Horizontal above ground spent fuel storage.

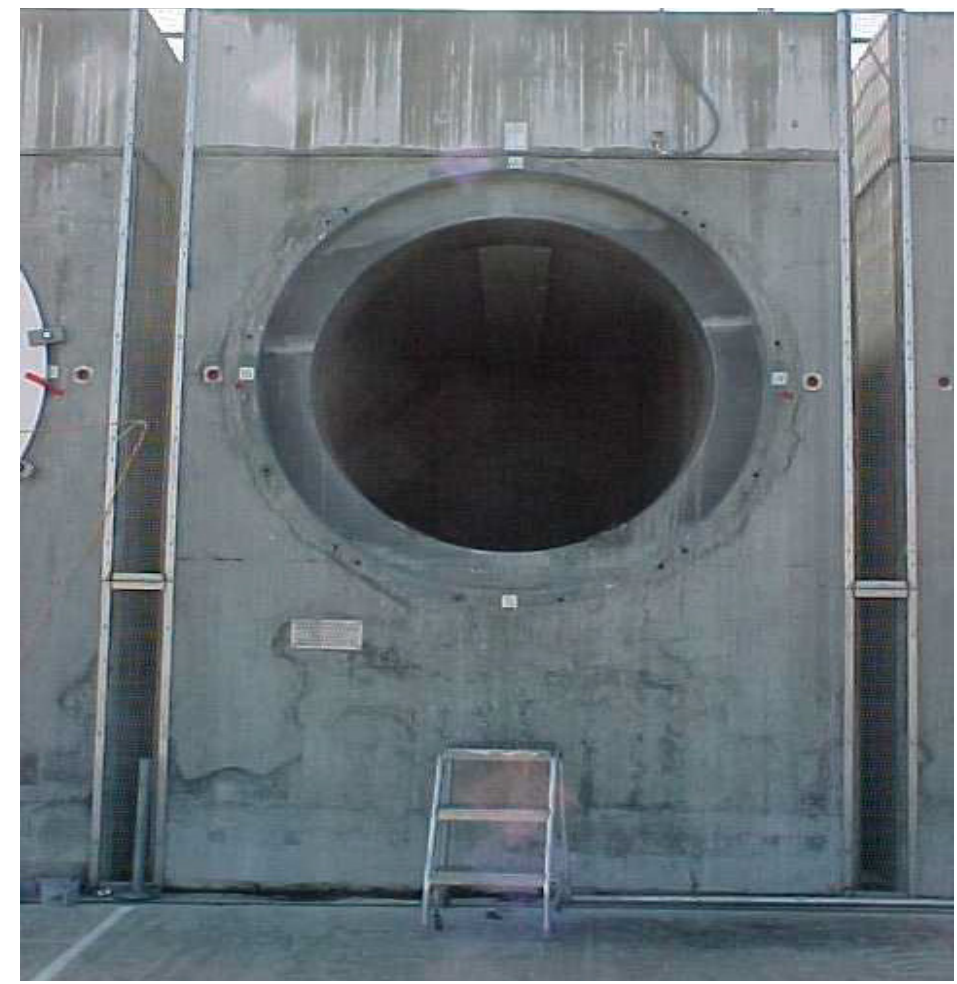

Figure 3-5. Close up view of horizontal above ground spent fuel storage. 
The decay period required to qualify waste for shipping in Type A shipping containers also was examined. Based on NRF projected waste inventories for 2018 , Ni-63 would average $1,650 \mathrm{Ci} /$ container (NRF 2010). The maximum activity of normal form radioactive material $\left(\mathrm{A}_{2}\right)$ for Ni-63 in $10 \mathrm{CFR}$ Part 71, Appendix A, is $810 \mathrm{Ci} /$ container. Therefore, the average waste container would have to be stored for about one half-life of 101 years to meet the qualifying criterion for shipment in a Type A container. This is a conservative estimate since it looks only at Ni-63. Both Co-60 and Fe-55 also exceed their respective $\mathrm{A}_{2}$ criteria. Application of the sum of fractions rule would result in an actual storage period that would be longer.

Calculations using shipping criteria, typical LLW WAC, and contact-handled waste definitions, all show that storage for over 80 years would be required to provide time for isotopes to decay to contact-handled LLW (see Appendix A).

Storage facilities do not exist to support this alternative. Construction of a new storage facility would likely be equal to or perhaps more expensive than construction of a permanent disposal facility. The technical and functional requirements for retrievability of the waste packages, long-term structural integrity, and accessibility for inspection of the containers during the period of storage would add significant cost to the storage facility relative to a disposal facility.

\subsubsection{Alternative 5-Development of an Onsite Remote-Handled LLW Disposal Facility}

A new onsite disposal facility would be developed as a new project, along with procurement of any necessary transportation equipment and construction of required infrastructure. It is assumed that a facility could be sited, constructed, and operated at the INL. The specific location for such a disposal facility would be identified as part of project development concurrent with the requisite NEPA evaluation of remote-handled LLW disposal capability alternatives.

\subsubsection{Alternative 6-Offsite Disposal (Multiple Locations)}

This section summarizes the evaluation of the alternative of offsite disposal for INL remote-handled LLW resin and activated metal waste streams. Eight candidate facilities for offsite disposal were identified through literature searches and contacts with disposal facility representatives. Appendix B contains the details of the offsite alternatives analyses. In Figure 3-6, the offsite facility locations discussed in this section are identified for reference.

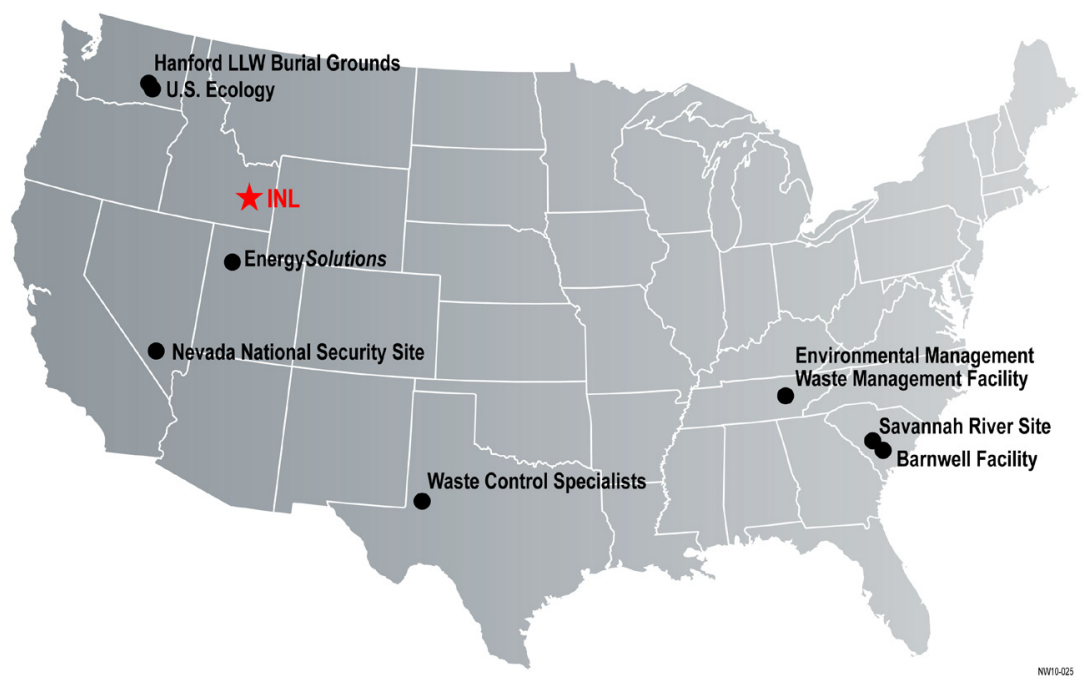

Figure 3-6. Offsite disposal facility locations. 


\subsubsection{Candidate Facility Descriptions}

The Barnwell Facility, located in Barnwell County, South Carolina, is operated by EnergySolutions under a lease and license issued by the State of South Carolina. The facility is licensed to accept a broad range of LLW for disposal. However, since June 30, 2008, Barnwell is allowed to accept only waste from generating facilities within the States of South Carolina, Connecticut, and New Jersey (i.e., the members of the Atlantic Compact).
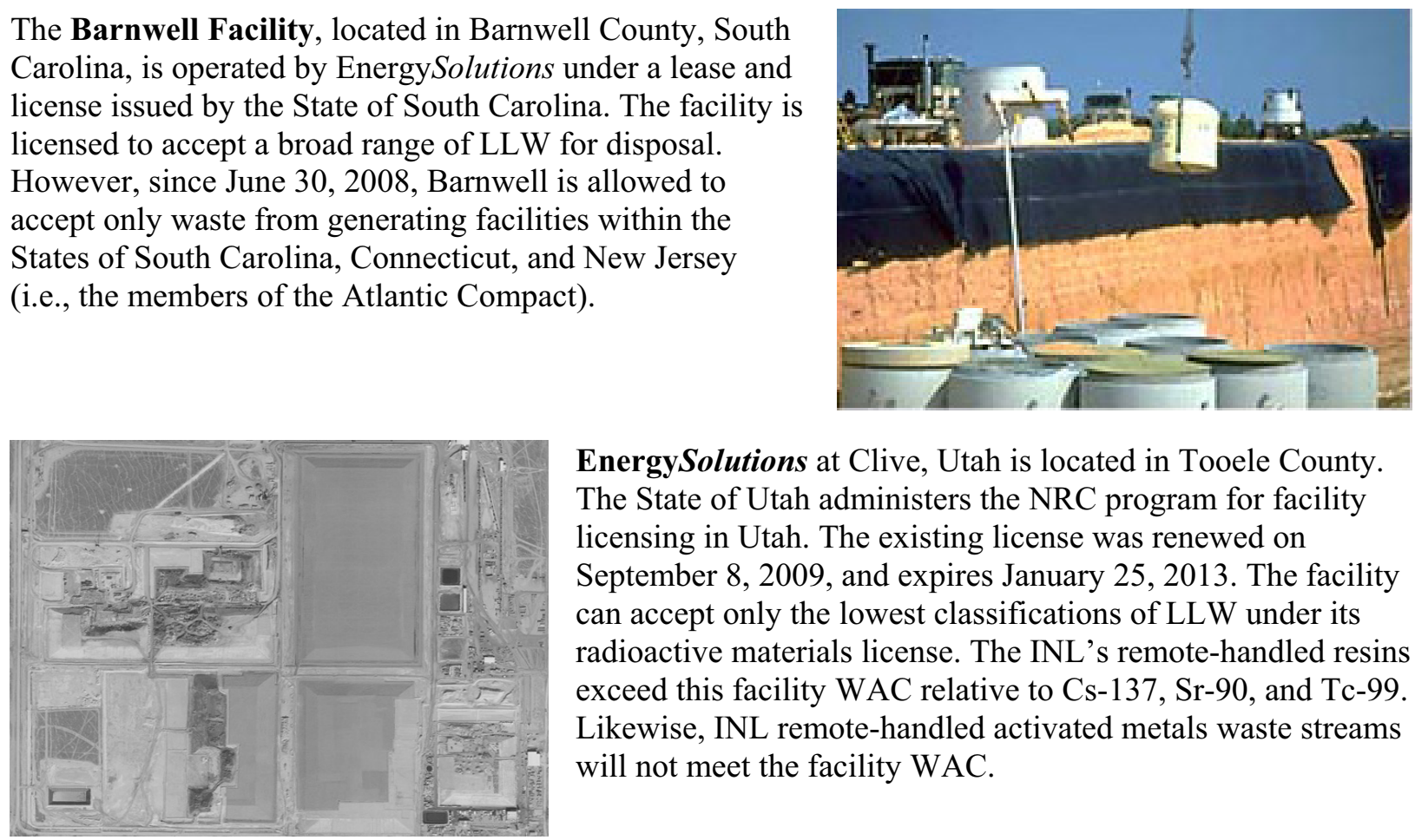

EnergySolutions at Clive, Utah is located in Tooele County. The State of Utah administers the NRC program for facility licensing in Utah. The existing license was renewed on September 8, 2009, and expires January 25, 2013. The facility can accept only the lowest classifications of LLW under its radioactive materials license. The INL's remote-handled resins exceed this facility WAC relative to Cs-137, Sr-90, and Tc-99. Likewise, INL remote-handled activated metals waste streams will not meet the facility WAC.

The Environmental Management Waste Management Facility (EMWMF) is located on the DOE Oak Ridge Reservation in Tennessee. EMWMF is limited to the receipt of LLW and waste containing hazardous constituents from cleanup activities at Oak Ridge and has been in operation since 2002. Management oversight of the EMWMF is the responsibility of DOE, the state, and the Environmental Protection Agency under the requirements of CERCLA (42 USC § 9601) and the Resource Conservation and Recovery Act (42 USC $\S 6901$ et seq.).
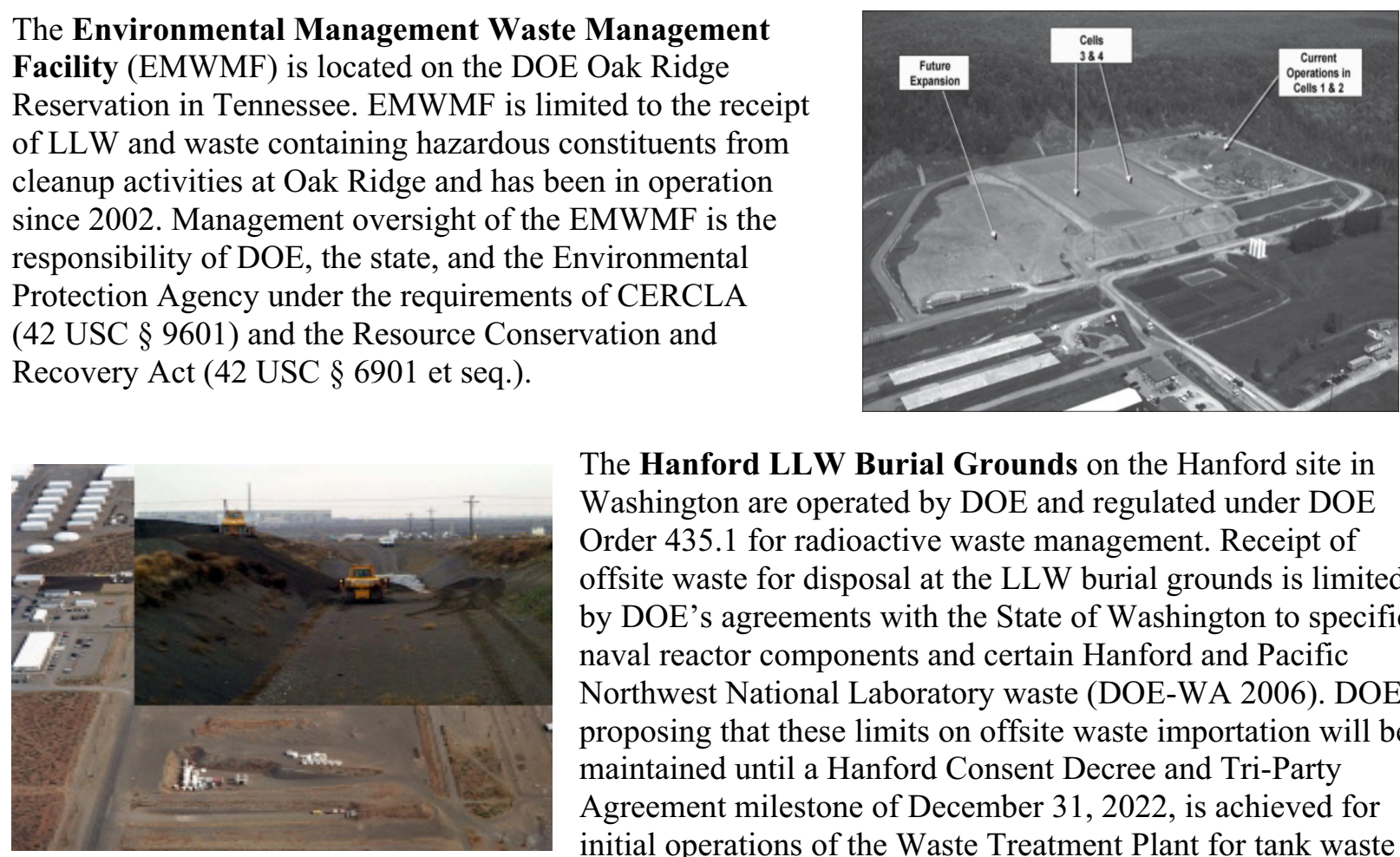

The Hanford LLW Burial Grounds on the Hanford site in Washington are operated by DOE and regulated under DOE Order 435.1 for radioactive waste management. Receipt of offsite waste for disposal at the LLW burial grounds is limited by DOE's agreements with the State of Washington to specific naval reactor components and certain Hanford and Pacific Northwest National Laboratory waste (DOE-WA 2006). DOE is proposing that these limits on offsite waste importation will be maintained until a Hanford Consent Decree and Tri-Party Agreement milestone of December 31, 2022, is achieved for initial operations of the Waste Treatment Plant for tank waste (DOE 2009c). Shipment of waste from INL to Hanford could not be planned to commence until after that date, which does not support the mission need for remote-handled LLW disposal. 
NNSS, previously known as the Nevada Test Site, occupies approximately $1,375 \mathrm{mi}^{2}$ in southeastern Nye County, Nevada. NNSS receives waste by truck only. The site is operated by DOE and regulated under DOE Order 435.1 for radioactive waste management. The state of Nevada participates in review of waste material profiles and has access to LLW disposal waste information through an Agreement in Principle with DOE (DOE-NV 1999). Not all of the INL remote-handled LLW meets the action level elements of the NNSS WAC. However, the waste that exceeds the NNSS WAC radionuclide action levels is a

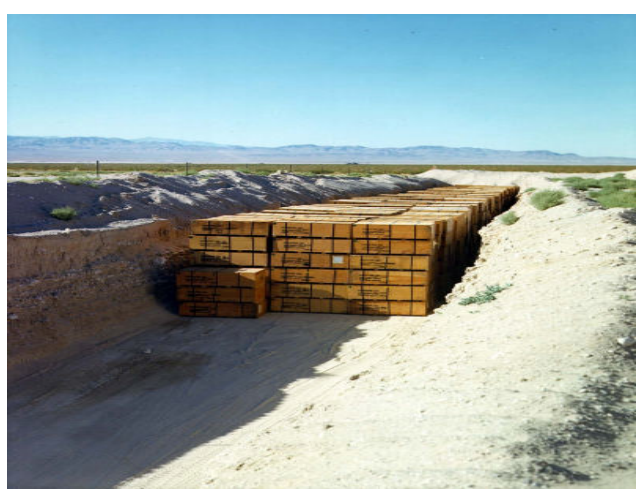
candidate for special performance assessments to authorize disposal. NNSS identified no issues that would cause the state to view the activated metals as unacceptable for disposal, although the facility has not received routine shipments of high-radiation waste of this nature in the past. The facility is scheduled to operate through the year 2027 under DOE's Office of Environmental Management and then would be transferred to the National Nuclear Security Agency (NNSA). Waste is disposed of in trenches.

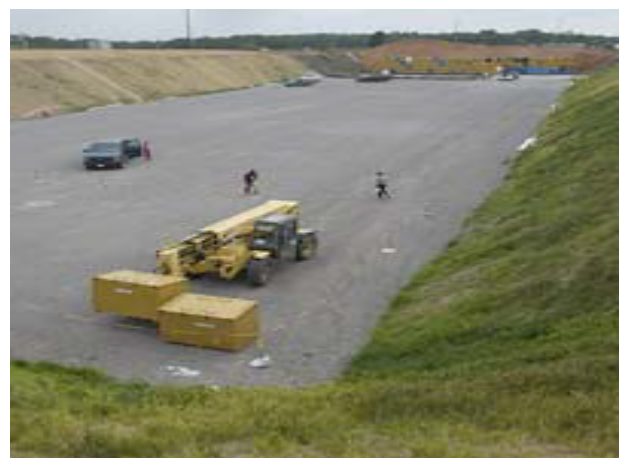

Savannah River Site LLW disposal operations are located in the central part of the Savannah River Site in South Carolina. The facility can receive waste by rail. The disposal facility is regulated by DOE under DOE Order 435.1. It includes engineered concrete vaults for low-activity and intermediate-activity waste disposal. In support of the Navy's mission, Savannah River Site accepts remote-handled LLW generated by the Naval Nuclear Propulsion Program from offsite. The Savannah River Site is not open to disposal of any other offsite waste. The DOE's Office of Environmental Management baseline for Savannah River Site has a planned facility closure date of 2031.

U.S. Ecology is located on 100 acres of land at the DOE Hanford site that are leased by the State of Washington from DOE. The facility has rail receipt capabilities. The State of Washington administers the NRC program for facility licensing in Washington. The existing license is valid through 2011. To date, the facility has received approximately $13,500,000 \mathrm{ft}^{3}$ of LLW and it has a remaining capacity of $44,000,000 \mathrm{ft}^{3}$. This disposal facility is for Northwest and Rocky Mountain Compact states. Disposal of LLW that is the responsibility of the federal government is subject to state approval. To date no such approval has been sought for DOE

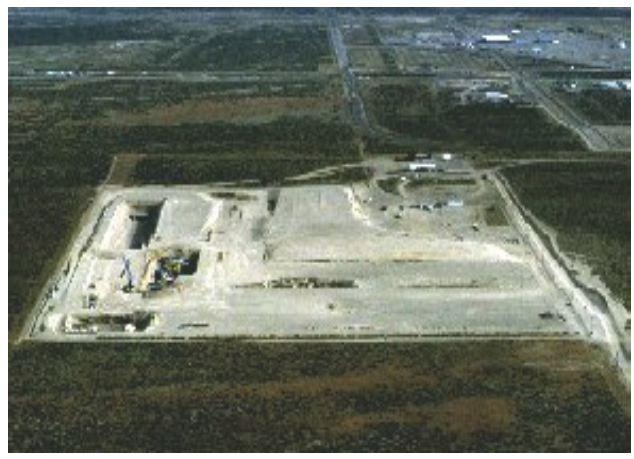
waste. The facility can accept a broad range of LLW but some of the INL's remote-handled LLW with high radiation levels would challenge the WAC. Not all of INL's remote-handled LLW activated metals will meet the facility WAC. 


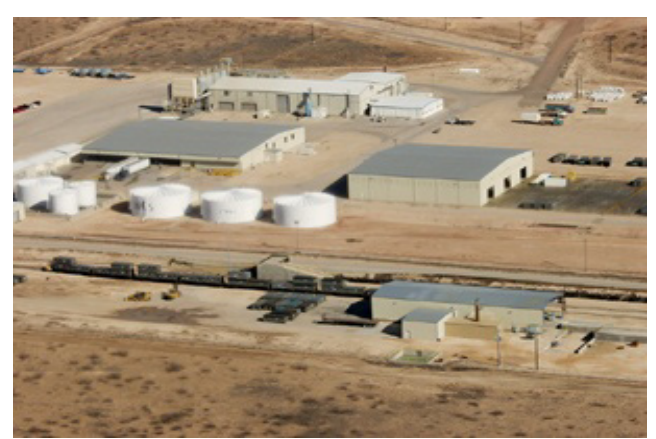

Waste Control Specialists (WCS) is a facility located in Andrew County, Texas, that will support disposal of federal LLW and Texas Compact waste in separate landfill cells. The State of Texas (the NRC authorized licensing authority) issued WCS a license for disposal of LLW on September 10, 2009, conditioned on completion of several administrative requirements. The facility is expected to be opened to LLW disposal in late 2010. Texas has a state law that requires DOE to take possession of the site after closure, if a "federal waste" site is opened. DOE and the Texas Commission on

Environmental Quality have signed a Memorandum of Agreement recognizing their respective responsibilities in the event DOE exercises its discretion to use the WCS Federal Waste Facility for LLW disposal. While the Memorandum of Agreement recognizes the rights and responsibilities of the parties, the DOE retains sole discretion on whether to award a prime contract for waste disposal to WCS, and whether to dispose any LLW or mixed LLW at the Federal Waste Facility. Therefore, whether the WCS facility will be selected by DOE for disposal of any LLW is unknown. As with the U.S. Ecology facility, a portion of the remote-handled activated metal waste is expected to exceed the disposal acceptance requirements at the WCS facility. Not all of INL's remote-handled LLW activated metals waste will meet the facility WAC.

\subsubsection{Alternative 7-Privatization of Remote-Handled LLW Disposal}

Privatization initiatives can be pursued by contracting the services, divestiture of formerly government functions, or transfer of assets by sale or other means.

The possibility of contracting for disposal with a new commercial facility that does not currently exist was considered. The total project cost for site activities to dispose of INL and tenant-generated remote-handled LLW at a new offsite commercial facility would be similar to that estimated for offsite disposal at any offsite alternative due to shipping cask requirements and other activities necessary to support offsite shipment. However, life-cycle costs would be uncertain and difficult to compare with any degree of accuracy. No known facilities are planned to commence within the time of the project mission need. The programmatic risks of speculating when, where, and whether such a facility would be placed in operation in time to support the mission need for uninterrupted disposal of INL and tenant-generated remote-handled LLW is simply too great to consider an unknown, new commercial facility as an option.

Alternatively, a combination of divestiture and asset transfer could be pursued for remote-handled LLW disposal. Under this scenario, INL would solicit a commercial entity to fund the design, construction, and operation of a new onsite remote-handled LLW disposal facility. It is unknown whether a commercial entity would be interested in such an undertaking in the time frame needed.

Because a commercial facility would be required to meet the same design requirements as a new facility, the commercial facility costs should approximate the costs that were estimated for new onsite construction as reflected in Alternative 5. Because of the small volume of waste projected for the facility, a "user-pays" cost recovery model would not be feasible for recovery of operating costs plus a return on investment. The commercial entity would expect DOE to bear some responsibility for operating costs regardless of the disposal volume. Therefore, the total costs to DOE for privatization would be higher than a DOE-owned facility.

A privatized disposal facility would require regulation by the NRC. This license could include restrictions on the types and classes of waste that could be received, and there is the potential that the facility's WAC would not include the entire INL remote-handled LLW inventory. All of INL's 
remote-handled LLW activated metals waste would not meet a new commercial facility's WAC. Thus, the privatization alternative comes with a significant amount of uncertainty and, therefore, risk.

\subsubsection{Alternative 8-No Action}

The no action alternative consists of DOE conducting no activities to ensure uninterrupted, remote-handled LLW disposal capabilities for remote-handled LLW generated at INL. Under this alternative, remote-handled LLW from NRF would continue to be disposed of in the SDA until it is full or must be closed in preparation for final CERCLA closure. No transport cask would be developed for shipment of waste from ATR and MFC to the SDA for disposal. Individual generators could continue normal operations that result in generation of remote-handled LLW only until interim storage capacity was exhausted. At that time, operational activities that generate the subject waste would cease or be significantly curtailed because of a lack of disposal capability, impacting mission critical activities.

Remote-handled LLW disposal capacity is critical to meeting the NNSA's mission to "provide the United States Navy with safe, militarily effective nuclear propulsion plants and to ensure the safe and reliable operation of those plants." All spent fuel from the navy's nuclear-powered fleet is sent to NRF for examination, processing, dry storage, and eventual shipment to a permanent geologic repository. A reliable disposal path for remote-handled LLW generated during spent fuel operations is essential to NRF's continued receipt and processing of Navy spent fuel to support the Naval Nuclear Propulsion Program and national security. Interim storage at NRF is possible for up to 2 years at which point the lack of a disposal path for remote-handled LLW would impact the ability to process spent fuel.

\subsection{Selection of Alternatives for Further Evaluation}

The possible alternatives were considered for their suitability in meeting the mission need for disposal capability for INL's remote-handled LLW beginning in FY 2018 and continuing through at least FY 2037. The criteria used are as follows:

- Capacity to accommodate INL's entire remote-handled LLW inventory. This criterion has two aspects. As a threshold, the alternative must have its doors open to receiving this waste from INL. Second, the alternative should provide management for disposal of INL's entire anticipated remote-handled LLW in terms of waste types, volumes, and concentrations.

- Availability of alternative beginning in FY 2018 and continuing through at least FY 2037. This criterion sets the critical timeframe within which the mission need must be satisfied.

- Effectiveness in achieving disposal in accordance with DOE Order 435.1. The DOE Radioactive Waste Management Manual implementing DOE Order 435.1 defines disposal as "emplacement of waste in a manner that ensures protection of the public, workers, and the environment with no intent of retrieval and that requires deliberate action to regain access to the waste."

Table 3-1 presents evaluation of the possible alternatives against these criteria.

\subsubsection{Results}

The alternatives of disposal at a new onsite facility and disposal offsite at NNSS are identified as the only two that are credible to meet mission need. The first was the new onsite facility (\#5). The second was offsite disposal (\#6), with NNSS being the only credible, currently available candidate facility. These two alternatives were carried forward for further evaluation in Section 4. 
A new onsite facility is qualified because it could be sited and configured to meet mission need. None of the other alternatives involving use of onsite capabilities could meet each criterion of availability, capacity, and effectiveness.

Because the use of special performance assessments may be able to qualify all of INL's remote-handled LLW for disposal at NNSS, and since NNSS is currently available, it was selected for further detailed analysis. If NNSS is suitable for all LLW, it is assumed that INL would only need to maintain one certification program for waste shipments, minimizing costs of program administration and oversight.

Analysis of costs, risks, and complexity of using NNSS will be considered a best case representative of scenarios in which changed circumstances might permit use of other offsite options for the remote-handled resins or a portion of the activated metal waste. 
Table 3-1. Summary of initial evaluation of remote-handled LLW disposal alternatives.

\begin{tabular}{|c|c|c|c|}
\hline Alternative & $\begin{array}{l}\text { Does alternative include all INL } \\
\text { remote-handled LLW streams? }\end{array}$ & $\begin{array}{l}\text { Is alternative available from } \\
\text { FY } 2018 \text { through FY 2037? }\end{array}$ & $\begin{array}{l}\text { Does alternative meet } \\
\text { mission need by providing } \\
\text { disposal capability? }\end{array}$ \\
\hline $\begin{array}{l}\text { \#1 Continued Disposal at } \\
\text { RWMC }\end{array}$ & No - RWMC projected to be full by 2020 & $\begin{array}{l}\text { No }- \text { RWMC would be closed under } \\
\text { INL cleanup agreement prior to } 2037\end{array}$ & Yes \\
\hline \multirow[t]{2}{*}{ \#2 Disposal at ICDF } & $\begin{array}{l}\text { No-design and construction of new } \\
\text { vaults would be required in order to } \\
\text { accept remote-handled LLW }\end{array}$ & $\begin{array}{l}\text { No - ICDF is slated to cease } \\
\text { receiving waste in } 2018\end{array}$ & \multirow[t]{2}{*}{ Yes } \\
\hline & No - only CERCLA waste accepted & & \\
\hline \#3 Interim Storage & Yes & Yes & No \\
\hline \#4 Storage for Decay & Yes & Yes & No \\
\hline \#5 New onsite facility & Yes & Yes & Yes \\
\hline \multicolumn{4}{|c|}{ \#6 Offsite disposal (multiple locations): } \\
\hline Barnwell Facility & No - no offsite waste accepted & NA & NA \\
\hline EnergySolutions & $\begin{array}{l}\text { No - license limits facility to acceptance } \\
\text { of only the lowest classification of LLW }\end{array}$ & Yes & Yes \\
\hline EMWMF & No - no offsite waste accepted & NA & NA \\
\hline $\begin{array}{r}\text { Hanford LLW Burial } \\
\text { Grounds } \\
\end{array}$ & No - no offsite waste accepted & NA & NA \\
\hline \multirow[b]{2}{*}{ Savannah River Site } & $\begin{array}{l}\text { Yes - could meet WAC with special } \\
\text { performance assessment }\end{array}$ & Yes & Yes \\
\hline & $\begin{array}{l}\text { No - Naval reactors activated metal } \\
\text { components and resins only }\end{array}$ & Yes & Yes \\
\hline U.S. Ecology & No - not all waste meets facility WAC & Yes & $\begin{array}{l}\text { Unknown - approval of } \\
\text { state of Washington } \\
\text { required }\end{array}$ \\
\hline WCS & No - not all waste meets facility WAC & Yes & $\begin{array}{l}\text { Unknown - DOE decision } \\
\text { to dispose any DOE waste } \\
\text { has not been made }\end{array}$ \\
\hline \#7 Privatization & No - not all waste meets facility WAC & $\begin{array}{l}\text { Unknown if private entity would } \\
\text { commit to schedule requirements }\end{array}$ & $\begin{array}{l}\text { Yes - only if return on } \\
\text { investment is feasible }\end{array}$ \\
\hline \#8 No action & No & No & No \\
\hline
\end{tabular}




\section{REMOTE-HANDLED LOW-LEVEL WASTE DISPOSAL ALTERNATIVE EVALUATION}

The two alternatives identified as having the best potential for meeting the mission need in Section 3 are described, evaluated, and compared in this section for purposes of recommending one alternative to implement the project.

\subsection{Detailed Analysis of Alternative 5: A New Onsite Disposal Facility for INL's Remote-Handled Low-Level Waste}

This section provides further detailed description and evaluation of the alternative of disposal of the INL's remote-handled LLW in a new onsite facility. The alternative is analyzed by applying the criteria of life-cycle cost, risk, complexity, stakeholder values, and regulatory compliance.

\subsubsection{Assumptions and Strategies}

The approach taken to define this alternative was to use existing information from the ICDF project with modifications to cost and schedule to reflect the current projected waste volumes for remote-handled LLW, NEPA regulations (42 USC § 4321 et seq.) versus CERCLA regulations (42 USC $§ 9601$ et seq.), safety analysis assumptions for a Hazard Category 2 facility, and historical information from remotehandled LLW disposal at RWMC. The following assumptions and strategies were used to develop the requirements and cost for a new onsite remote-handled LLW disposal facility:

- The facility would include approximately 247 vaults of three different designs to accommodate three types of waste disposal liners.

- The design includes engineered features that take into account operational impacts and are protective of groundwater.

- The remote-handled LLW can be handled in a similar manner as it is today at the SDA. A crane and support equipment are used to move the cask over the top of the vault, lower the liner into the vault, and seal the vault.

- Acquisition of a transport cask for activated metals waste streams from ATR and MFC would be part of the project.

The following actions or approvals would be needed from DOE, according to the preliminary schedules shown in Appendix C, to implement this alternative:

- CD-1 through CD-4 for an onsite remote-handled LLW disposal facility and associated infrastructure

- CD-1 through CD-4 for procurement of a transport cask for shipments from MFC and ATR

- EA determination and Finding of No Significant Impact based on the EA for the Remote-Handled LLW Disposal Project

- Disposal Project Disposal Authorization Statement for a new disposal facility is based on a review of the facility's performance assessment, composite analysis, performance assessment and composite analysis maintenance, preliminary closure plan, and preliminary monitoring plan.

- Operational readiness review for construction project. 


\subsubsection{Costs}

The costs for onsite disposal were estimated for a new onsite disposal facility using a design based on the remote-handled LLW disposal practices in the SDA. Existing information from ICDF and RWMC, with cost and schedule modifications to reflect projected remote-handled LLW waste volumes, applicable regulations, and safety analysis assumptions for a Hazard Category 2 nuclear facility, were used for the analysis. A 20-year operating life was assumed. The costs for developing a new remote-handled LLW disposal facility included siting, design, and construction of infrastructure; acquisition of a cask and new liner handling equipment; maintenance of disposal authorization and safety documentation; project management; operations; and closure. No costs for changes in infrastructure for shipping, packaging, and temporary storage are anticipated to be needed in order to achieve onsite disposal of remote-handled LLW.

Costs are escalated and adjusted for inflation and include a DOE-held contingency. The estimated total project cost range for construction of a new facility is $\$ 68.4$ to $\$ 92.2 \mathrm{M}$. The estimated life-cycle cost range for the onsite disposal facility construction, operation, and closure through the year 2038 is between \$158.4 to \$238.4M.

\subsubsection{Risk}

For purposes of this analysis, risks are defined as events that negatively impact schedule, resources, or performance of the project. Overall risk for this alternative is considered low because the risks involved with siting, construction, and operation are largely under the control of DOE. Performance does not involve out-of-state transport. The facility will be designed using experience, practices, and materials, which introduce little design risk. The potential risk of long-term impacts to the aquifer can be mitigated through use of design, operating, monitoring, and closure standards. Environmental risks of onsite disposal are mitigated by the absence of exposed waste and the more robust containment provided by a vault system in comparison to pit disposal operations.

If planned funding is not available, impact to proposed schedule could require development of interim storage for remote-handled LLW at an onsite facility.

\subsubsection{Complexity}

Complexity is defined as the degree to which the alternative can be achieved with minimal coordination with external agencies or vendors and minimal interference with INL or tenant operations. The onsite disposal alternative involves just one facility. Because all shipments occur within site boundaries, existing transport practices and equipment can be used for NRF remote-handled activated metals and resin waste streams. This completely eliminates the costs, risks, and schedule impacts of development of a new offsite transportation cask system for NRF and simplifies the coordination and management of shipments. A new cask would be procured for ATR and MFC activated metals waste streams. This project would be integrated with the onsite disposal facility project to reduce costs.

\subsubsection{Stakeholder Values}

The criterion of stakeholder values is defined as the degree to which the alternative can gain the appropriate level of approval from key stakeholders. A proposal to develop a new onsite waste disposal facility would likely generate some stakeholder response. Stakeholder concerns would be expected to include siting; concerns that a new INL facility would be made available for disposal of waste from offsite; and protection of the Snake River Plain Aquifer. Stakeholders will have involvement through the NEPA process and other established public and regulator forums, as appropriate. If the alternative of a 
new facility is selected, stakeholder concerns about location can be addressed via the site selection criteria used in a facility siting assessment. Stakeholders also have expressed concerns that a new INL facility would be made available for disposal of waste from offsite; however, use of INL for offsite waste disposal is not a decision DOE has made pursuant to NEPA. INL is restricted to disposal of LLW from onsite only based on DOE's ROD for LLW (DOE 2000). Concerns for protection of the aquifer have been paramount and therefore, stakeholder reactions to disposal of LLW onsite could be mixed. In particular, concern could be expressed regarding the fact that the landfill cells are not equipped with engineered liners.

\subsubsection{Regulatory Compliance}

Regulatory compliance is defined as whether the alternative can be executed in compliance with regulatory approvals and requirements. It is assumed this facility would be located, designed, constructed and operated in compliance with applicable regulatory requirements. DOE Order 435.1 guides regulation of LLW disposal, and a Disposal Authorization Statement would be issued pursuant to this order. There are no regulatory compliance issues identified.

\subsection{Detailed Analysis of Alternative 6: Offsite Disposal of Remote-Handled Low-Level Waste at the Nevada National Security Site}

This section summarizes the detailed evaluation of the potential for offsite disposal of all INL remote-handled LLW at NNSS, including resins generated by ATR and NRF and activated metals generated by ATR, NRF, MFC, and potentially other INL activities. ATR resins are already being disposed of at NNSS.

\subsubsection{Assumptions and Strategies}

Assumptions and strategies used to develop this alternative include the following:

- Based on the current CERCLA closure schedule, the planning date for closure of the remote-handled LLW vaults is 2017.

- All necessary documentation, procedures, and infrastructure must be in place prior to October 2017.

- Disposal of INL remote-handled LLW will be required at least through the year 2037.

- Waste profiles will be developed by INL waste generators and approved by NNSS.

- A maximum exposure rate of 30,000 R/hour for the remote-handled LLW activated metals is selected for purposes of analysis. Projections indicate that future radiation levels are expected to be below this level. Any waste that is over 30,000 R/hour must be handled on a case-by-case basis.

The following approvals would be needed from DOE, according to the preliminary schedules shown in Appendix C, to implement this alternative:

- $\mathrm{CD}-1$ through CD-4 for procurement of casks

- CD-1 through CD-4 for NNSS infrastructure construction

- CD-1 through CD-4 for NRF infrastructure construction 
- $\quad$ EA determination and Finding of No Significant Impact based on the EA for the Remote-Handled LLW Disposal Project

- Operational readiness review for construction projects.

With NNSS selected as a credible offsite alternative, shipping and packaging considerations include the following:

- ATR is estimated to require six shipments per year for its resin waste, with $6 \mathrm{~m}^{3}$ in each shipment. The ATR remote-handled LLW ion-exchange resins are currently shipped offsite in the $\mathrm{NuPac}$ 14-210L shipping container. It is assumed this procedure will continue for offsite shipments of remote-handled LLW resins from ATR.

- Commercial truck-loaded casks will be required to meet the configuration and shielding requirements for offsite shipment of remote-handled LLW ion-exchange resins and activated metals from NRF and activated metals from ATR and MFC. To send these remote-handled LLW streams to NNSS, six casks will be needed to make 48 shipments per year ( 43 from NRF, 2 from MFC, and 3 from ATR) at an anticipated waste generation of $48 \mathrm{~m}^{3} /$ year. A trailer is needed for each cask. Four shielded transfer systems also will be required to accommodate disposal shipping activities. Five casks would be used by NRF and one will be shared between ATR and MFC. In keeping with the existing practice at NRF for the 55-ton scrap cask and to minimize costs, it is assumed that only one new cask and liner handling system will be installed at NRF. Therefore, the NRF resin waste stream will be shipped offsite using the same commercial cask system as would be used for the activated metals waste stream. This practice would be conservative with respect to the shielding required for the characteristics of the resin waste stream.

- Operational and infrastructure considerations for shipping offsite to NNSS include the following:

Offsite shipments will require use of certified Type B casks, which require added costs for design and testing, introduce payload limitations in comparison to the 55-ton scrap cask, and require added testing prior to shipment and other considerations not required for onsite cask shipments.

- Implementation of commercial cask operations for offsite shipments would require significant operational changes in the NRF processing and storage pools that would impact the primary mission of fuel processing to support the Naval Nuclear Propulsion Program. For example, a cask with a $1-\mathrm{m}^{3}$ capacity would require tripling the number of NRF shipments and require additional sizing of waste due to its smaller payload.

- $\quad$ Offsite disposal would necessitate significant facility modifications to support waste shipments using commercial Type B casks instead of the existing 55-ton scrap cask. For example, NRF would need to design a new loading station for a commercial cask or repackage to a different disposal liner/system. The current system is above water, whereas a commercial cask would be loaded underwater and require an above water decontamination system. Installation of this new equipment would require removal of cask loading equipment and installing structural improvements. NRF also would need capability to handle the new cask size, conduct material sizing, and handle the liners. These facility modifications would be needed even if the existing Expended Core Facility were replaced by a recapitalized facility. The existing Expended Core Facility also would need to maintain the ability to process and ship remote-handled LLW to address backlog and decommissioning waste beyond FY 2020. 
- $\quad$ In any proposed recapitalization project to replace the aging NRF Expended Core Facility, the capacity of the new facility would have to be larger to accommodate the increased number of NRF shipments due to the smaller commercial cask payload for offsite shipments.

- $\quad$ Activated metals from MFC would be segregated and repackaged into a form suitable for transfer to a cask for shipping.

- $\quad$ NNSS will need to adopt specific procedures, perform special performance assessments, and rent or acquire extra equipment in order to receive and dispose of this waste. Due to the number of NRF shipments, a crane and excavator may need to be dedicated exclusively to receipt of NRF shipments at NNSS. A decontamination station will need to be constructed and associated processes and procedures developed.

\subsubsection{Cost}

The costs for preparation and offsite disposal of remote-handled LLW activated metals and resins at NNSS from FY 2018 through FY 2037 include escalation throughout the performance period.

Costs for disposal at NNSS include:

- Acquisition of casks and cask transfer hardware

- Development of material profiles and waste characterization

- NNSS disposal charges

- Maintenance and training costs

- Transportation costs

- Costs for design, purchase, and installation of a new loading station at NRF

- Sizing equipment, including saw to size waste to smaller commercial cask

- Pool refurbishment.

Costs for disposal at NNSS are based on current charges. However, future disposal costs are uncertain, as costs charged to any generator in a given year are based on the total amount of waste disposed of at the facility by all generators. (Total disposal costs for FY 2009 were \$21.5M.) NNSS maintenance and training costs are included; however, costs of infrastructure changes at NNSS have not been fully assessed and are not included here. Therefore, costs may increase for offsite disposal at NNSS if the disposal site (NNSS) needs to recover costs for required infrastructure changes.

The costs for disposal of remote-handled LLW resins from ATR assume the continued use of the shipping cask and liners currently in use.

Total costs through 2037 range from $\$ 389$ to $\$ 834$ M. Costs for transportation and disposal of the activated metals and NRF ion-exchange resins account for the bulk of these costs and are attributable to the limited volume of waste that can be included in a shipment and the resulting number of shipments required. Appendix $\mathrm{C}$ provides additional cost and schedule details for this alternative. 
The total project cost for establishing offsite disposal capability for INL remote-handled waste and the life-cycle costs for disposing of INL-generated, remote-handled resins and activated metals at NNSS were estimated to be substantially higher than the analogous cost for the onsite option.

\subsubsection{Risk}

For purposes of this analysis, risks are defined as events that negatively impact schedule, resources, or performance of the project. Shipping waste offsite has inherent risks associated with commercial shipment of radioactive waste. These include routine exposure to shipping crews and the public, potential for involvement in serious accidents or of rerouting and delays due to accidents not involving the shipment itself, and attractiveness to terrorists for diversion or destruction. There is also the possibility that involvement of other jurisdictions could delay shipments or otherwise disrupt the waste disposition program.

Due to facility constraints at NRF, the large increase in number of shipments and added complexity of loading shipments would directly impact fuel processing operations which would adversely impact state agreements (NRF 2009).

Future disposal costs that would be charged to the generator in a given year are based on that generator's contribution to the total amount of waste disposed of at the facility. There is a risk that disposal costs will increase over time as the volume of waste shipped to NNSS decreases. The INL costs could increase significantly to support the base facility costs for disposal operations at NNSS. There is the possibility that toward the end of NNSS' operating life, INL will have to support the full burden of the facility (FY 2010 operating costs are forecast to be $\$ 21.8 \mathrm{M}$ ). With offsite commercial facilities (e.g., U.S. Ecology and WCS), future costs also are uncertain since costs are set by the receiving facilities based on market conditions.

Shipping remote-handled activated metal and resin LLW to NNSS results in a single point failure if NNSS is unable to receive the waste due to stakeholder or regulator concerns, because no provision will have been made for onsite disposal and there is no backup offsite alternative.

\subsubsection{Complexity}

Complexity is defined as the degree to which the alternative can be achieved with minimal coordination with external agencies or vendors and minimal interference with INL or tenant operations. Accomplishment of this alternative involves coordination of schedules, interfaces, and project execution between INL and another DOE facility. In addition to the direct effort required to implement the alternative, additional projects must be carried out to acquire new shipping cask systems, develop cask loading processes, and provide new infrastructure and equipment at NNSS and NRF.

In addition, while NNSS has received remote-handled LLW in the past, it has not routinely received shipments of high-radiation waste of this nature and impacts to infrastructure have not been fully addressed. Acquisition of remote-controlled handling equipment, such as a crane and front-end loader, will be required. Stand-off and shielding requirements will likely interfere with or temporarily halt normal operations during off-loading of the remote-handled activated metals. At NRF, pool refurbishment and other infrastructure projects would be required.

Coordinating the interrelated cost and schedule demands of multiple projects introduces a measure of complexity and risk into this alternative. 


\subsubsection{Stakeholder Values}

The criterion of stakeholder values is defined as the degree to which the alternative can gain the appropriate level of approval from key stakeholders. While the State of Idaho and stakeholders may view this alternative in a positive light in that waste will be leaving the state, stakeholders outside Idaho may have a negative view due to receipt and disposal of out-of-state waste. The general public also may view transportation of numerous highly radioactive shipments over public highways in a negative way.

\subsubsection{Regulatory Compliance}

Regulatory compliance is defined as whether the alternative can be executed in compliance with regulatory approvals and requirements. NNSS is regulated by DOE and disposal is not anticipated to be a problem from a technical standpoint. However, the State of Nevada participates in review of waste material profiles and has access to LLW disposal information through an Agreement in Principle with DOE (DOE-NV 1999). Based on their review of the waste streams, characteristics, and ongoing experience with the state agency, DOE/NNSS has not identified any issues that they believe would cause the state to view the remote-handled LLW as unacceptable for disposal. However, there is risk that the state review of the waste streams' characteristics could result in a different conclusion or that the political climate could change in the future and be less favorable to accepting these waste streams.

\subsection{Comparison of Final Alternatives}

The detailed information on Alternatives 5 and 6 was considered and each alternative was ranked in accordance with the criteria identified in Table 4-1. Each criterion was assigned a relative weighting factor from 1 to 3 . Each alternative was assigned a score of 1 or 2 for each criterion, with 1 being assigned to the preferred alternative for that respective criterion; that is, a rank of 1 was assigned to the alternative with the lower cost, smaller impact, or least opposition. A total score was obtained by multiplying the weighting factor times the rank for each criterion and then summing all the scores for the individual criteria. The alternative with the lowest total score represents the preferred alternative for providing continued, uninterrupted remote-handled LLW disposal capability for INL operations.

Based on the ranking presented in Table 4-1, the preferred alternative is development of a new, onsite, remote-handled LLW disposal facility. Onsite disposal of INL and tenant-generated, remote-handled LLW has the lowest life-cycle cost to DOE and provides the lowest risk of potential impacts on the DOE Office of Nuclear Energy and the Office of Naval Reactors. Costs are reduced through avoidance of costs to develop transportation infrastructure and to conduct offsite shipments. Project risks, such as uncertainty of availability of offsite facilities, are eliminated using onsite disposal. Reliance on other activities, programs, or third parties in order to achieve disposal also is minimized, reducing disposal complexity.

The only criterion by which the onsite alternative was not preferred was that of Idaho stakeholder opposition, indicating a project risk to be addressed as part of project planning and implementation.

Offsite disposal, in addition to having a higher life-cycle cost due to the limitations on the amount of remote-handled LLW that can be packaged into each container for transport, is complicated by transportation issues associated with transporting highly radioactive waste in commerce and the infrastructure and processing changes at the generating facilities, specifically NRF, that would be required to support offsite disposal. 
Table 4-1. Ranking of alternatives for Idaho National Laboratory remote-handled low-level waste disposal capability.

\begin{tabular}{|c|c|c|c|c|c|c|}
\hline $\begin{array}{l}\text { Evaluation } \\
\text { Category }\end{array}$ & Criteria & $\begin{array}{l}\text { Weighting } \\
\text { Factor }\end{array}$ & \multicolumn{2}{|c|}{ Alternative Rank ${ }^{1}$} & \multicolumn{2}{|c|}{ Total Weighted Score ${ }^{2}$} \\
\hline Risk & $\begin{array}{l}\text { Potential impacts on DOE Office of Nuclear Energy } \\
\text { and Office of Naval Reactors operations (Risk to } \\
\text { Mission Need) }\end{array}$ & 3 & 1 & 2 & 3 & 6 \\
\hline Cost & $\begin{array}{l}\text { Life-cycle cost to DOE Office of Nuclear Energy } \\
\text { and Office of Naval Reactors }\end{array}$ & 2 & 1 & 2 & 2 & 4 \\
\hline Cost & Capital project expenditure & 2 & 1 & 2 & 2 & 4 \\
\hline Complexity & $\begin{array}{l}\text { Interaction of third parties in regulation of waste } \\
\text { transport/disposal activities }\end{array}$ & 1 & 1 & 2 & 1 & 2 \\
\hline $\begin{array}{l}\text { Stakeholder } \\
\text { values }\end{array}$ & Other host state stakeholder opposition & 2 & 1 & 2 & 2 & 4 \\
\hline $\begin{array}{l}\text { Regulatory } \\
\text { compliance }\end{array}$ & $\begin{array}{l}\text { Certainty of achieving disposal for INL's } \\
\text { remote-handled LLW }\end{array}$ & 2 & 1 & 2 & 2 & 4 \\
\hline $\begin{array}{l}\text { Regulatory } \\
\text { compliance }\end{array}$ & $\begin{array}{l}\text { Compliance with DOE Order } 435.1 \\
\text { (disposal at generation site) }\end{array}$ & 1 & 1 & 2 & 1 & 2 \\
\hline & Total & & & & 19 & 32 \\
\hline
\end{tabular}

1. Lower number is the more preferred alternative.

2. Score is rank times weighting factor; Low score is preferred. 


\section{SUMMARY AND RECOMMENDATIONS}

This report presents the evaluation of the alternatives for disposal of remote-handled LLW generated by activities on the INL Site after closure of the SDA. The objective of this report is to provide a recommendation on the preferred alternatives for future remote-handled LLW disposal, after systematic consideration of cost, schedule, and risks of the credible alternatives for both offsite and onsite disposal.

Based on the ranking analysis, the order of recommendation for the two final alternatives is as follows:

1. Alternative 5-Construct a new remote-handled LLW vault facility and dispose of all remote-handled LLW on the INL Site

2. Alternative 6 - Ship all remote-handled LLW to NNSS for disposal.

The onsite disposal alternative was ranked higher than the alternative of offsite disposal in all categories except Idaho stakeholder opposition, having the lowest cost, lowest risk, and being the least complex to implement. Figure 5-1 illustrates the cost advantages of the onsite disposal alternative as lifecycle costs over the duration of the project. It shows that building a facility on the INL Site for disposal of remote-handled LLW has the lowest life-cycle cost. While both alternatives involve initial investments, the onsite alternative has a lower growth rate and a more level funding profile. For purposes of comparison, Figure 5-2 shows cumulative life-cycle costs by alternative.

The alternative of shipping offsite to NNSS involves significant challenges. Shipping waste offsite has inherent risks associated with commercial shipment of radioactive waste. These include routine exposure to shipping crews and the public, potential for involvement in serious accidents or rerouting and delays due to accidents not involving the shipment itself, and attractiveness to terrorists for diversion or destruction. It is the more complex and, therefore, riskier alternative, requiring changes to infrastructure at multiple locations and acquisitions of material requiring third party certification. Second, the increased number of offsite shipments from NRF compared to onsite shipments would create significant operational constraints and burdens on NRF and potentially conflict with NRF's primary mission to support the NNPP. Finally, this alternative does not offer a guaranteed solution. Reliance on special performance assessments for regular waste shipments has significant risk. Individual shipments may be sufficiently out of the norm to be unable to qualify for disposal. Over reliance on routine exceptions may cause the validity of the special performance practice to be questioned halting a series of shipments.

The onsite disposal alternative involves lower risk because it presents no offsite transportation or disposal considerations. In the recommended alternative, the risks are all, at least to some degree, under DOE control. Procurement of cask systems for offsite transportation is eliminated, decreasing cost and schedule risk. Coordination among a series of parallel programs is not required. Dependence on the cooperation of third parties, such as disposal site operators or states other than Idaho, is reduced to the absolute minimum. The onsite disposal alternative does involve increased Idaho stakeholder concerns as compared to offsite disposal. Stakeholder considerations will be addressed as part of the NEPA process, which will provide opportunity for comment on DOE's proposed action. In addition to a formal public comment period, stakeholder input also will be solicited via a series of public meetings and forums.

Successful implementation of the recommended alternative depends on the availability of planned funding. Significant delay in funding could require establishment of onsite storage. 


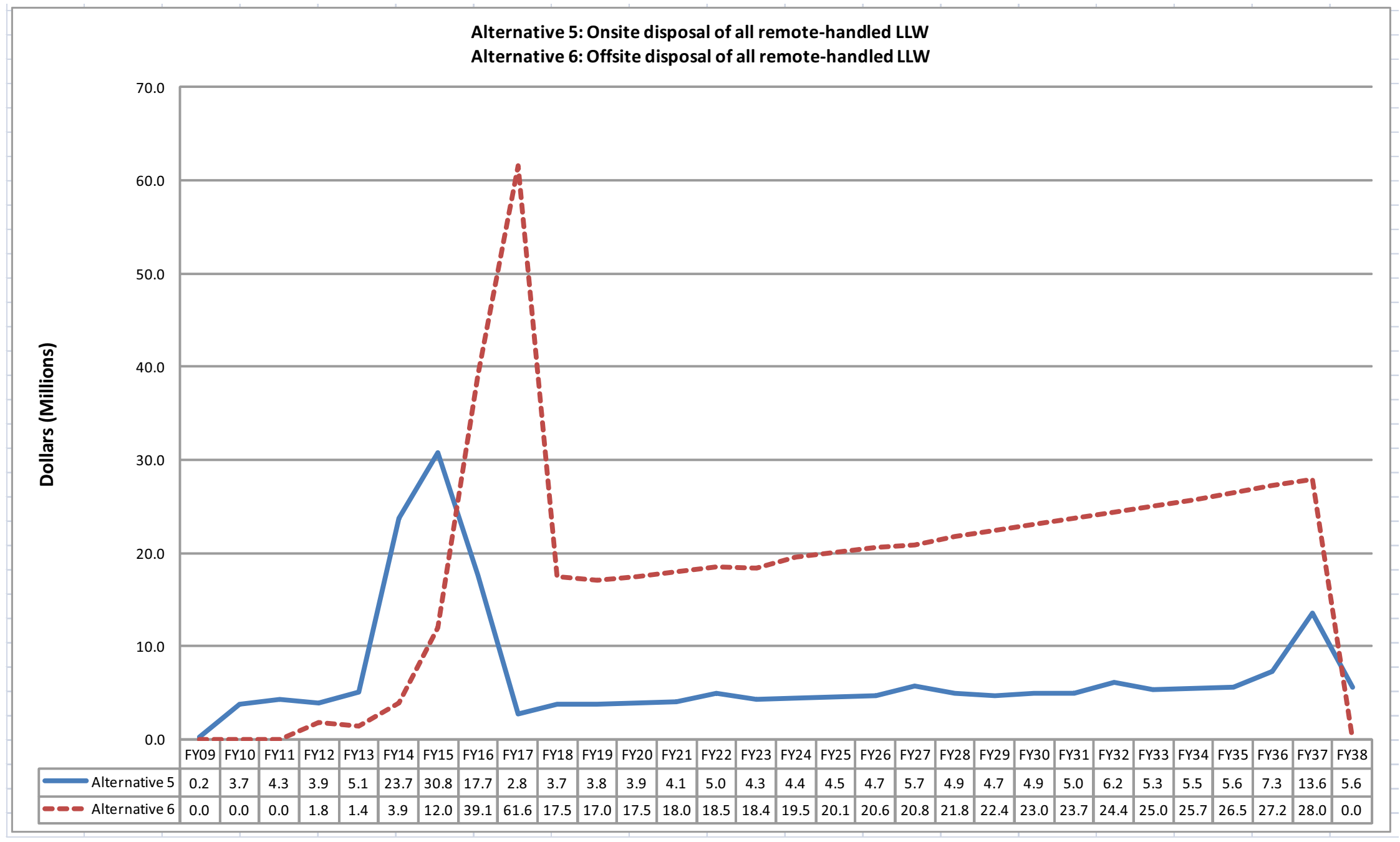

Figure 5-1. Annual project costs by disposal alternative. 


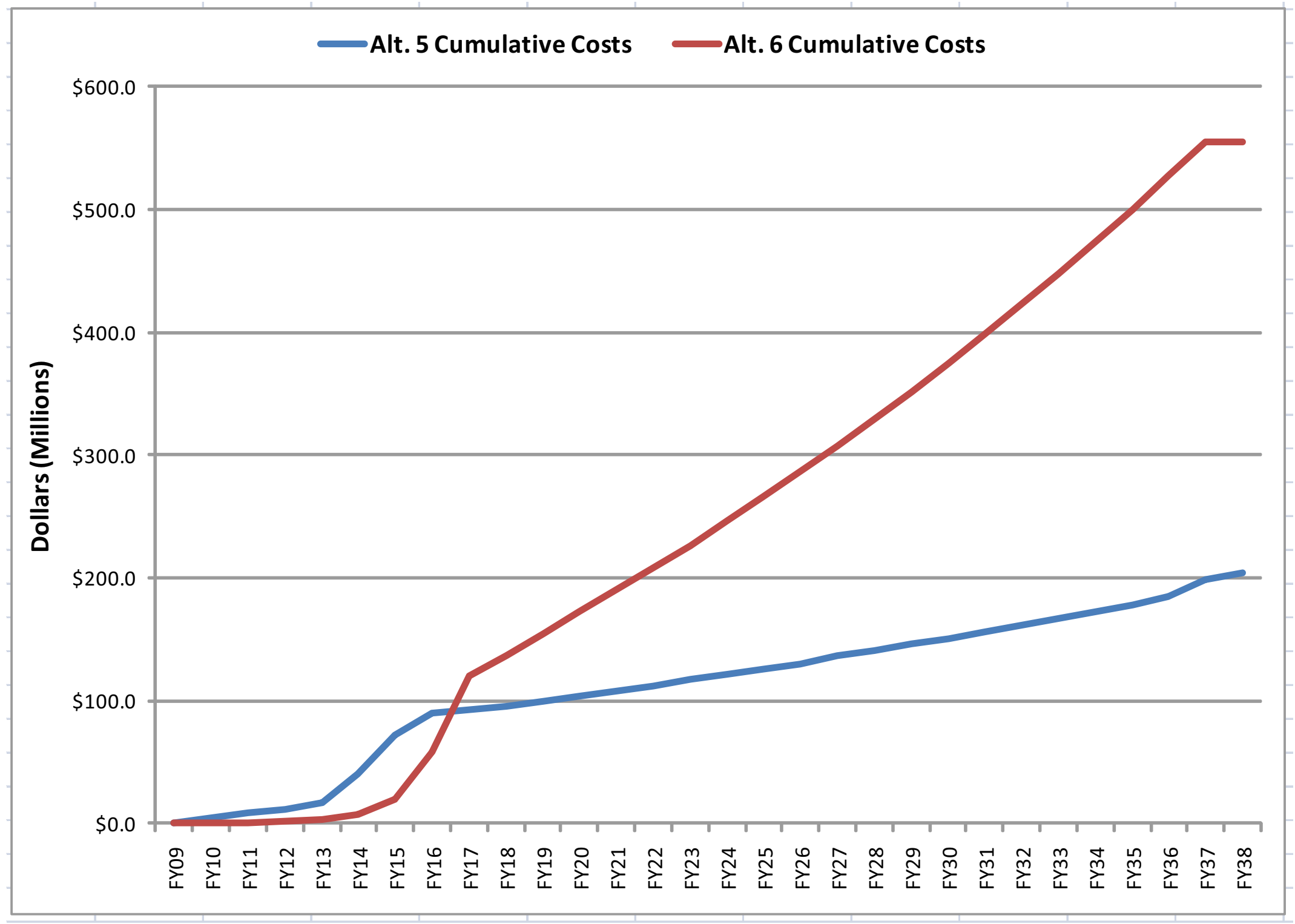

Figure 5-2. Cumulative comparison costs by disposal alternative. 


\section{REFERENCES}

10 CFR 61, 2002, Title 10, "Energy," Part 61, "Licensing Requirements for Land Disposal of Radioactive Waste," Code of Federal Regulations, Office of the Federal Register.

40 CFR 191, 2002, Title 40, "Protection of the Environment," Part 191, "Environmental Radiation Protection Standards for Management and Disposal of Spent Nuclear Fuel, High-Level and Transuranic Radioactive Wastes," Code of Federal Regulations, Office of the Federal Register.

42 USC § 4321 et seq., 1970, "National Environmental Policy Act,” United States Code, January 1, 1970.

42 USC $\S 6901$ et seq., 1976, "Resource Conservation and Recovery Act (Solid Waste Disposal Act)," United States Code, October 21, 1976.

42 USC $\S 9601$ et seq., 1980, "Comprehensive Environmental Response, Compensation and Liability Act of 1980 (CERCLA/Superfund)," United States Code, December 11, 1980.

Collé R., B. E. Zimmerman, P. Cassette, and L. Laureano-Perez, 2008, “63Ni, Its Half-life and Standardization: Revisited," Applied Radiation and Isotopes, 66(1): p. 60-68.

DOE, 2000, "Record of Decision for the Department of Energy's Waste Management Program: Treatment and Disposal of Low-Level Waste and Mixed Low-Level Waste; Amendment to the Record of Decision for the Nevada Test Site," 65 Federal Register 10061, February 25, 2000.

DOE, 2009a, Mission Need Statement for the Idaho National Laboratory Remote-Handled Low-Level Waste Disposal Project, U.S. Department of Energy.

DOE, 2009b, Guidance Regarding Low-Level and Mixed Low-Level Waste Disposal Decisions, Memorandum, U.S. Department of Energy, Office of Environmental Management, August 21, 2009.

DOE, 2009c, "Draft Tank Closure and Waste Management Environmental Impact Statement for the Hanford Site, Richland, Washington (Draft TC \& WM EIS)," (DOE/EIS-0391-D), October 2009.

DOE-ID, 1991, Federal Facility Agreement and Consent Order for the Idaho National Engineering Laboratory, Administrative Record No. 1088-06-29-120, U.S. Department of Energy Operations Office; U.S. Environmental Protection Agency, Region 10; Idaho Department of Health and Welfare, December 4, 1991.

DOE-ID, 1999, Final Record of Decision: Idaho Nuclear Technology and Engineering Center: Operable Unit 3-13, DOE/ID-10660, Rev. 0, Idaho National Laboratory, October 1999.

DOE-ID, 2007a, Proposed Plan for Radioactive Waste Management Complex Operable Unit 7-13/14, DOE/ID-11288, Rev. 00, October 17, 2007.

DOE-ID, 2007b, ICDF Complex Waste Acceptance Criteria, DOE/ID-10881, Rev. 4, Idaho National Laboratory, July 2007.

DOE-ID, 2008, Record of Decision for Radioactive Waste Management Complex Operable Unit 7-13/14, DOE/ID-11359, Rev. 0, September 2008. 
DOE-NV, 1999, Agreement in Principal Between the Department of Energy and the State of Nevada, DE-GM08-99NV13571, June 1999.

DOE Order 413.3B, 2010, "Program and Project Management for Acquisition of Capital Assets," U.S. Department of Energy, July 28, 2006.

DOE Order 435.1, 2001, "Radioactive Waste Management," U.S. Department of Energy, August 28, 2001.

DOE-WA, 2006, SETTLEMENT AGREEMENT re: WASHINGTON v. BODMAN, Civil No. 2:03-cv-05018-AAM, January 6, 2006.

NRF, 2009, J. W. Frazier Letter to File, "NRF Waste Canister Contingency Storage Beyond 2015," NRF-WS-433, dated September 15, 2009.

NRF, 2010, Letter to L. A. Harvego, INL, Subject: Long Range Radioactivity estimate for NRF RHLLW, NRF-WS-473, March 2010.

Unterweger, M. P., 2002, "Half-life measurements results at the National Institute of Standards and Technology," Proc. Tenth ICRM meeting, Applied Radiation and Isotopes, 56, pp. 125-130. 


\section{DEFINITIONS}

\begin{tabular}{|c|c|}
\hline Term & Definition \\
\hline Activated metals & $\begin{array}{l}\text { Structural materials from a nuclear facility that have been subjected to neutron } \\
\text { irradiation and contain radionuclide activation products within the matrix of the } \\
\text { material. }\end{array}$ \\
\hline Cask & $\begin{array}{l}\text { A container that provides appropriate shielding and structural integrity for the } \\
\text { transportation and/or storage of spent fuel and other radioactive materials. The } \\
\text { cask serves several functions. It provides chemical, mechanical, thermal and } \\
\text { radiological protection, and dissipates decay heat during handling, transport, and } \\
\text { storage. }\end{array}$ \\
\hline Closure & $\begin{array}{l}\text { Administrative and technical actions taken at a waste disposal facility at the end } \\
\text { of its operating lifetime to assure it is left in a state that is protective of human } \\
\text { health and the environment. }\end{array}$ \\
\hline Complexity & $\begin{array}{l}\text { As applied to LLW disposal alternatives, complexity refers to the number of } \\
\text { disposal sites, parallel construction or procurement projects, and external } \\
\text { vendors and agencies that must be coordinated for the overall alternative to } \\
\text { achieve all waste management objectives. External refers to organizations other } \\
\text { than Battelle Energy Alliance, INL Site tenant, and DOE. }\end{array}$ \\
\hline Contact-handled LLW & $\begin{array}{l}\text { LLW whose external dose rate is sufficiently low as to not require additional } \\
\text { shielding or special handling. Definitions vary among facilities but are usually } \\
\text { expressed as a dose rate equivalent at a specific distance from the waste } \\
\text { package. This report defines contact-handled LLW as waste having a dose } \\
\text { equivalent rate of less than } 200 \mathrm{mrem} / \text { hour at contact. }\end{array}$ \\
\hline Curie (Ci) & $\begin{array}{l}\text { Non-SI unit of measure of the rate of decay of a radioactive material. One Curie } \\
\text { is } 37 \text { billion disintegrations per second (Becquerel). } \\
(1 \mathrm{Ci}=3.7 \times 1010 \mathrm{~Bq}) \text { A milliCurie (abbreviated } \mathrm{mCi}) \text { is equal to } \\
\text { one-thousandth of a Curie. }\end{array}$ \\
\hline Disposal & $\begin{array}{l}\text { Emplacement of waste in a manner that ensures protection of the public, } \\
\text { workers, and the environment with no intent of retrieval and that requires } \\
\text { deliberate action to regain access to the waste. }\end{array}$ \\
\hline Disposal, offsite & $\begin{array}{l}\text { Disposal of the LLW or portions thereof at commercial radioactive waste } \\
\text { disposal facilities or at DOE managed sites other than the INL. }\end{array}$ \\
\hline Disposal, onsite & Disposal of the LLW or portions thereof within the INL Site boundary. \\
\hline Radioactive waste & $\begin{array}{l}\text { Solid, liquid, and gaseous materials from nuclear operations that are radioactive } \\
\text { or become radioactive and for which there is no further use. }\end{array}$ \\
\hline
\end{tabular}




\begin{tabular}{|c|c|}
\hline Term & Definition \\
\hline \multirow[t]{2}{*}{ Radioactive waste, LLV } & $\begin{array}{l}\text { Low-level radioactive waste is radioactive waste that is not high-level } \\
\text { radioactive waste, spent nuclear fuel, transuranic waste, byproduct material } \\
\text { (as defined in Section 11e.(2) of the Atomic Energy Act of 1954, as amended), } \\
\text { or naturally occurring radioactive material. }\end{array}$ \\
\hline & $\begin{array}{l}\text { In a sense, LLW is defined by what it is not and consequently is the broadest } \\
\text { category of waste. It encompasses materials that are slightly above natural } \\
\text { radiation background levels to highly radioactive materials which require } \\
\text { extreme caution when handling (greater than Class C). Categorization as LLW } \\
\text { does not depend on the level of radioactivity it contains. }\end{array}$ \\
\hline rem & $\begin{array}{l}\text { Non-SI unit of equivalent dose that measures the effects of ionizing radiation on } \\
\text { humans. One rem is equal to } 0.01 \text { sievert. A millirem (abbreviated mrem) is } \\
\text { equal to one-thousandth of a rem. }\end{array}$ \\
\hline Remote-handled LLW & $\begin{array}{l}\text { LLW that requires special tools, equipment, and procedures for handling to } \\
\text { minimize personnel exposure. Definitions vary among facilities but are usually } \\
\text { expressed as a dose rate equivalent at a specific distance from the waste } \\
\text { package. This report defines remote-handled LLW as waste having a dose } \\
\text { equivalent rate of equal to or greater than } 200 \mathrm{mrem} / \text { hour at contact. }\end{array}$ \\
\hline Risk & $\begin{array}{l}\text { An analysis of possible events, their probabilities of occurrence, and their } \\
\text { potential consequences for the disposal option being evaluated. }\end{array}$ \\
\hline \multirow[t]{4}{*}{ Transuranic waste } & $\begin{array}{l}\text { Transuranic waste is radioactive waste containing more than } 100 \text { nanocuries } \\
(3,700 \text { becquerels }) \text { of alpha-emitting transuranic isotopes per gram of waste, } \\
\text { with half-lives greater than } 20 \text { years, except for the following: }\end{array}$ \\
\hline & 1. High-level radioactive waste \\
\hline & $\begin{array}{l}\text { 2. Waste that the Secretary of Energy has determined, with the concurrence of } \\
\text { the Administrator of the Environmental Protection Agency, does not need the } \\
\text { degree of isolation required by the } 40 \text { CFR Part } 191 \text { disposal regulations }\end{array}$ \\
\hline & $\begin{array}{l}\text { 3. Waste that the NRC has approved for disposal on a case-by-case basis in } \\
\text { accordance with } 10 \text { CFR Part } 61 \text {. }\end{array}$ \\
\hline $\begin{array}{l}\text { Waste acceptance } \\
\text { criteria }\end{array}$ & $\begin{array}{l}\text { A document that specifies the quantitative or qualitative criteria that must be } \\
\text { met for waste to be accepted by the operator of a specific repository for } \\
\text { disposal, or by the operator of a storage facility for storage. Waste acceptance } \\
\text { requirements might include, for example, restrictions on the radionuclide } \\
\text { concentration or the total activity of particular radionuclides (or types of } \\
\text { radionuclide) in the waste or requirements concerning the waste form or waste } \\
\text { package. }\end{array}$ \\
\hline Waste inventory & $\begin{array}{l}\text { Quantity, radionuclides, activity and waste form characteristics of waste for } \\
\text { which an operator is responsible. }\end{array}$ \\
\hline Waste generator & The operating organization of a facility or activity that generates waste. \\
\hline
\end{tabular}




\section{Appendix A}

\section{Details of Evaluation of Onsite Alternatives for Remote-Handled Low-Level Waste Disposal}




$$
\text { A-2 }
$$




\section{Appendix A \\ Details of Evaluation of Onsite Alternatives \\ for Remote-Handled Low-Level Waste Disposal \\ A-1. INTRODUCTION}

This appendix presents the detailed evaluation of the onsite alternatives component of the list of alternatives presented in Section 1.2 of the Alternatives Analysis report for disposal of remote-handled low-level waste (LLW). They are as follows:

- Alternative 1: Continued disposal at the Radioactive Waste Management Complex (RWMC)

- Alternative 2: Disposal at the Idaho Comprehensive Environmental Response, Compensation, and Liability Act (CERCLA) Disposal facility (ICDF)

- Alternative 3: Interim storage

- Alternative 4: Storage for decay

- Alternative 5: Development of an onsite remote-handled LLW disposal facility

- Alternative 7: Privatization of remote-handled LLW disposal

- Alternative 8: No action.

The key criteria and general assumptions for the evaluation are described in Sections 1.3 and 1.4, respectively, of the Alternatives Analysis report.

This section evaluates all of the remote-handled LLW onsite disposal alternatives and presents additional detailed evaluation of the most credible option. A summary of the onsite alternatives assessment is included in Section A-3. The potential onsite options were screened against criteria, including risk, life-cycle cost, stakeholder values, and regulatory compliance to determine which alternative represents the maximum probability of successfully meeting the mission need. The results of this screening, in which a new onsite disposal facility is treated as the base case for each of the criteria, also are included in Section A-3. Performance of the other alternatives is discussed with reference to the base case. A more detailed discussion of the risk considerations for the various onsite alternatives also is discussed.

\section{A-2. DESCRIPTION OF ONSITE ALTERNATIVES}

For the analysis of onsite alternatives, it was assumed that the remote-handled LLW inventory will be retained and disposed of onsite or stored for future disposal beginning in Fiscal Year (FY) 2018, upon closure of the RWMC Subsurface Disposal Area (SDA) LLW disposal facility. The mission need identified seven alternatives (including no action) for onsite disposal or storage. No technical barriers have been identified that would prevent implementation of an onsite alternative. 


\section{A-2.1 Alternative 1-Continued Disposal at the RWMC}

The majority of Idaho National Laboratory (INL)-generated remote-handled LLW has historically been disposed of in the SDA at RWMC, see Figure A-1. Therefore, the alternative of continuing disposal at RWMC was identified in the Mission Need Statement. This alternative is not part of the current plans for the SDA, which is undergoing permanent closure pursuant to a Record of Decision (ROD) (DOE-ID 2008) issued under the INL's Federal Facility Agreement/Consent Order (FFA/CO) for cleanup of the site (DOE-ID 1991). Disposal of remote-handled LLW in concrete disposal vaults at the SDA will continue until the facility is full or until it must be closed in preparation for final remediation of the SDA. Subject to the provisions of the ROD, the Office of Environmental Management contractor will implement the SDA closure in a manner that supports operation of the remote-handled LLW disposal vaults through the end of FY 2017, if possible. As of the end of FY 2009, there were 81 unused vaults available for disposal of remote-handled LLW at the RWMC. This will provide sufficient disposal capacity for Naval Reactors Facility (NRF) waste only until approximately 2019, at the current generation rate for NRF. The number of vaults cannot be expanded at this location because they are bounded by areas previously used for waste disposal and no excavation would be possible.

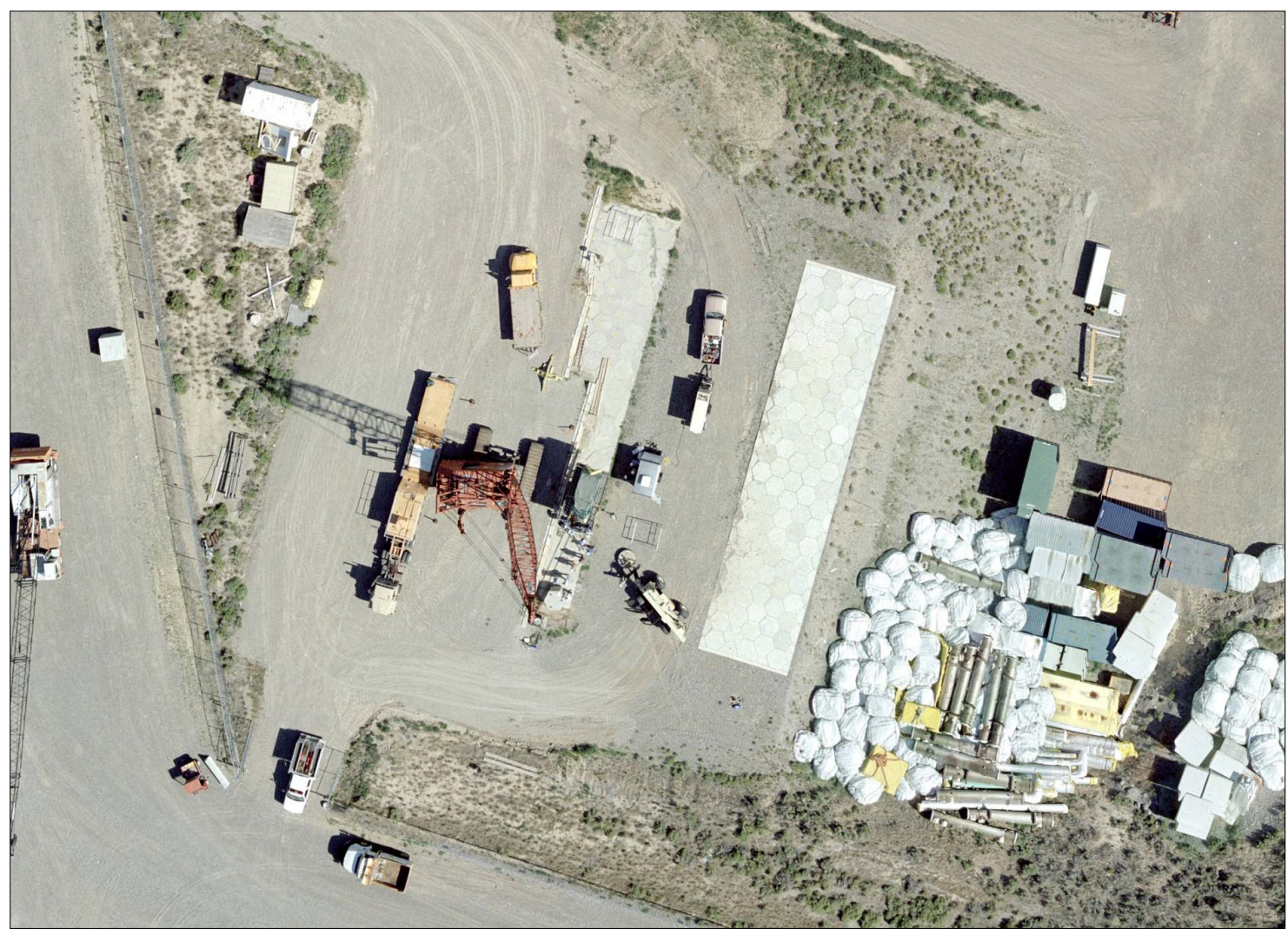

Figure A-1. Aerial view of Radioactive Waste Management Complex historical vault operations.

Under the current ROD for cleanup, it would not be feasible to continue to operate the remote-handled LLW disposal facility at the SDA while the remainder of the SDA is being closed. The RWMC SDA vaults currently used for disposal of remote-handled LLW are surrounded by pits that must be closed and covered as part of the final cleanup remedy. Continued operation of these SDA vaults for disposal of remote-handled LLW would interfere with cleanup operations and prevent final closure of the SDA. 
The SDA is undergoing permanent closure pursuant to a ROD (DOE-ID 2008) issued under the INL's FFA/CO for cleanup of the site (DOE-ID 1991). Subject to the provisions of the ROD, the Office of Environmental Management contractor will implement the SDA closure in a manner that supports operation of the remote-handled LLW disposal vaults through the end of FY 2017, if possible. Continued operation of the SDA for 20 years after 2017 would effectively implement the no action clean-up alternative for 20 years, and this is not acceptable. As identified in the proposed plan for cleanup at the RWMC (DOE-ID 2007a), the no action alternative was not selected because it failed to meet threshold cleanup criteria of protecting human health and the environment and complying with environmental requirements.

The determinant factors in this case are the high risk that, if pursued, this alternative would not be successful in overcoming the regulatory hurdles due to stakeholder resistance on the required schedule and disposal capacity is not available to satisfy the mission need for more than a few years.

This analysis does not develop detailed cost information for this alternative because it is not considered a credible option for establishing continued, uninterrupted remote-handled LLW disposal capability for INL

\section{A-2.2 Alternative 2-Disposal at the Idaho CERCLA Disposal Facility}

The Department of Energy (DOE) authorized a remedial design/remedial action under CERCLA for the Idaho Nuclear Technology and Engineering Center (INTEC) in accordance with the Waste Area Group 3, Operable Unit 3-13 ROD (DOE-ID 1999). The Operable Unit 3-13 ROD requires removal and onsite disposal of some of the CERCLA remediation waste generated within the boundaries of INL. The ICDF Complex was constructed immediately south of INTEC to meet this requirement.

The ICDF Complex, see Figure A-2, was designed and authorized to be the consolidation point for any CERCLA-generated waste within INL boundaries, accepting Waste Area Group 3 waste and other INL CERCLA actions. It includes the necessary subsystems and support facilities to provide a complete waste management system for waste generated as part of INL environmental management remediation activities. The ICDF landfill meets the substantive requirements of the Resource Conservation and Recovery Act (RCRA), Subtitle C; the Idaho Hazardous Waste Management Act (State of Idaho 1983); DOE Order 435.1; and the Toxic Substances Control Act (15 USC § 2601 et seq.) polychlorinated biphenyl landfill design and construction requirements. The landfill can currently receive any CERCLA-generated waste from the INL that meets the land disposal restriction requirements delineated in the ICDF complex waste acceptance criteria (WAC) (DOE-ID 2007b).

In theory, remote-handled LLW generated beyond FY 2017 could be disposed of at ICDF following closure of the SDA. Therefore, the Mission Need Statement identified the use of ICDF as a potential alternative for remote-handled LLW disposal. ICDF has two lined disposal cells but does not include vaults for disposal of remote-handled wastes. Management of remote-handled LLW in the existing ICDF landfill cells would require special consideration of the high radiation levels associated with these waste streams, including possible construction of disposal vaults similar to those currently used in the SDA. Additional infrastructure changes and adoption of appropriate operating procedures would also be required to support receipt of casks of remote-handled LLW from onsite generators.

ICDF is currently limited to receipt of only CERCLA waste and has an assumed closure date in 2018. In addition to the required infrastructure changes, these issues must also be addressed: An extension to operations, a design change since the facility was not designed to accept remote-handled LLW, and a change to the ICDF WAC to accept non-CERCLA-generated waste streams from INL and NRF operations in the existing ICDF landfill. These actions would first require approval of the DOE Office of 
Nuclear Energy, DOE Office of Environmental Management, DOE Idaho Operations Office (DOE-ID), the State of Idaho, and the Environmental Protection Agency (EPA) to amend the CERCLA ROD establishing ICDF, because the existing ROD limits the ICDF to waste generated from INL CERCLA activities only (DOE-ID 1999). The regulatory agencies could be resistant to any ROD changes that would have the potential to introduce competing priorities for ICDF disposal capacity. Additionally, the risk assessment, radiological performance assessment, and composite analysis for the facility would need to be revised to reflect disposal of remote-handled LLW in the CERCLA cells. The probability of obtaining all necessary approvals to expand the ICDF WAC to support planning for modifications to ICDF to accept remote-handled LLW is extremely low.

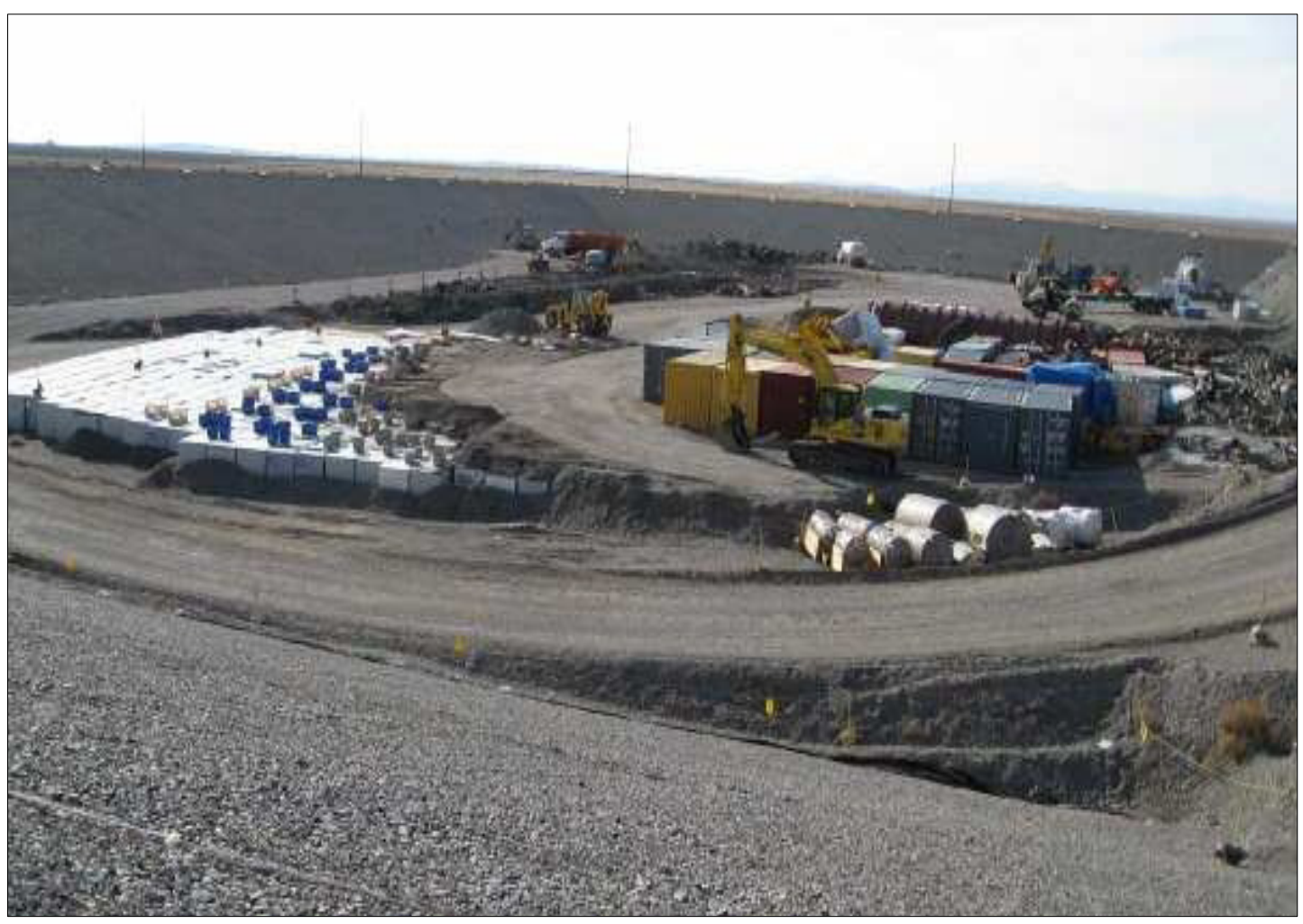

Figure A-2. The Idaho CERCLA Disposal Facility.

In theory, if regulatory hurdles were cleared, remote-handled LLW generated beyond FY 2017 could be disposed of at ICDF following closure of the SDA. As stated, the ICDF has two lined disposal cells but does not include vaults for disposal of remote-handled wastes. Management of remote-handled LLW in the existing ICDF landfill cells would likely require construction of disposal vaults similar to those currently used in the SDA. Additional infrastructure changes and adoption of appropriate operating procedures would also be required to support receipt of casks and unloading of the liners containing the remote-handled LLW from onsite generators.

There are other technical and design issues with using the existing CERCLA cells, as well. Current plans call for increasing the elevation of the disposal cell surface only another $10 \mathrm{ft}$ above the current elevation. This would be a marginal depth for even one liner per vault, whereas the existing practice has an excavation depth sufficient for at least two liners in each vault. In addition, placing the vaults within a lined cell could later result in increasing mobility of the radioactive constituents of the waste, which would dictate against placing vaults in the existing cells. The design of the CERCLA cells does not meet 
the requirements of the preferred design for remote-handled low-level radioactive waste but would not prevent the construction of a new adjacent facility to take advantage of some existing ICDF infrastructure.

A detailed cost analysis was not performed, but the lifecycle cost of disposal of remote-handled low-level waste within the ICDF is likely to be higher than a new facility because the moderate savings in using some existing infrastructure would be more than offset by the costs of a ROD amendment and revising the WAC.

Given the complex process for obtaining the required changes to the regulatory approvals, as well as new design and construction requirements, the risk that this alternative could not be implemented in time to meet the mission need by 2017, if ever, is too great to pursue this option. Therefore, onsite disposal of remote-handled LLW in the existing ICDF landfill cells is not a credible option for meeting the mission need of establishing continued, uninterrupted remote-handled LLW disposal capability for INL.

\section{A-2.3 Alternative 3-Interim Storage}

This alternative is defined as storage of remote-handled LLW either at the generator facilities or at another acceptable, safe location until the disposal capacity discussed in the Mission Need Statement is available. NRF currently stores its remote-handled LLW within the canals and fuel storage pool of the facility until it is transferred to RWMC for disposal. Current operational schedules at NRF provide for a maximum interim storage capacity of approximately 2 years. Exceeding this interim storage capacity would significantly impact fuel-handling activities at NRF until such time as the remote-handled waste could be transferred to another facility for continued interim storage or disposal.

The Advanced Test Reactor (ATR) also has limited interim storage capacity. The current interim canal storage for activated metals is full. Waste must be dispositioned from this location prior to the next core internals change-out planned for 2015.

While DOE could invest in expansion of the interim storage capacity at both facilities, such expansion would not provide a long-term solution for disposal of INL-generated remote-handled LLW; it would only delay a decision to some future date. Additionally, there are no other existing or planned facilities onsite to which the remote-handled LLW could be transferred for interim storage without significant capital and operational investment to provide interfaces with the NRF and ATR cask systems, to provide the necessary shielding, and to accommodate remote-handled LLW management operations.

The fundamental technical and functional design requirements for a storage facility, like the facility depicted in Figures A-3 and A-4, would be the same as those for the disposal facility for safe handling and minimization of worker exposure. However, the storage facility would have added requirements to guarantee retrievability of the waste packages and to ensure safe conditions for routine inspection and integrity of the storage vaults. Therefore, while additional interim storage capacity could be established, this option would represent a significant capital expenditure without providing an actual solution to the permanent disposal of remote-handled LLW generated at INL beyond FY 2017 and is not considered a credible alternative.

If the remote-handled LLW were stored above ground, the high radiation readings would require a minimum of 5-ft thickness of steel-reinforced concrete for shielding. The above-ground structure would also require significant steel reinforcement to meet applicable seismic requirements. The soil provides shielding and structural stability for the planned below ground disposal. The material costs of the precast concrete vaults (below ground) are estimated to cost $\$ 8,000$ per vault. In comparison, if the same vault 
dimensions were constructed for above ground storage using steel reinforced concrete with required 5-ft thick concrete to provide shielding, the estimated material cost per vault is $\$ 31,500$.

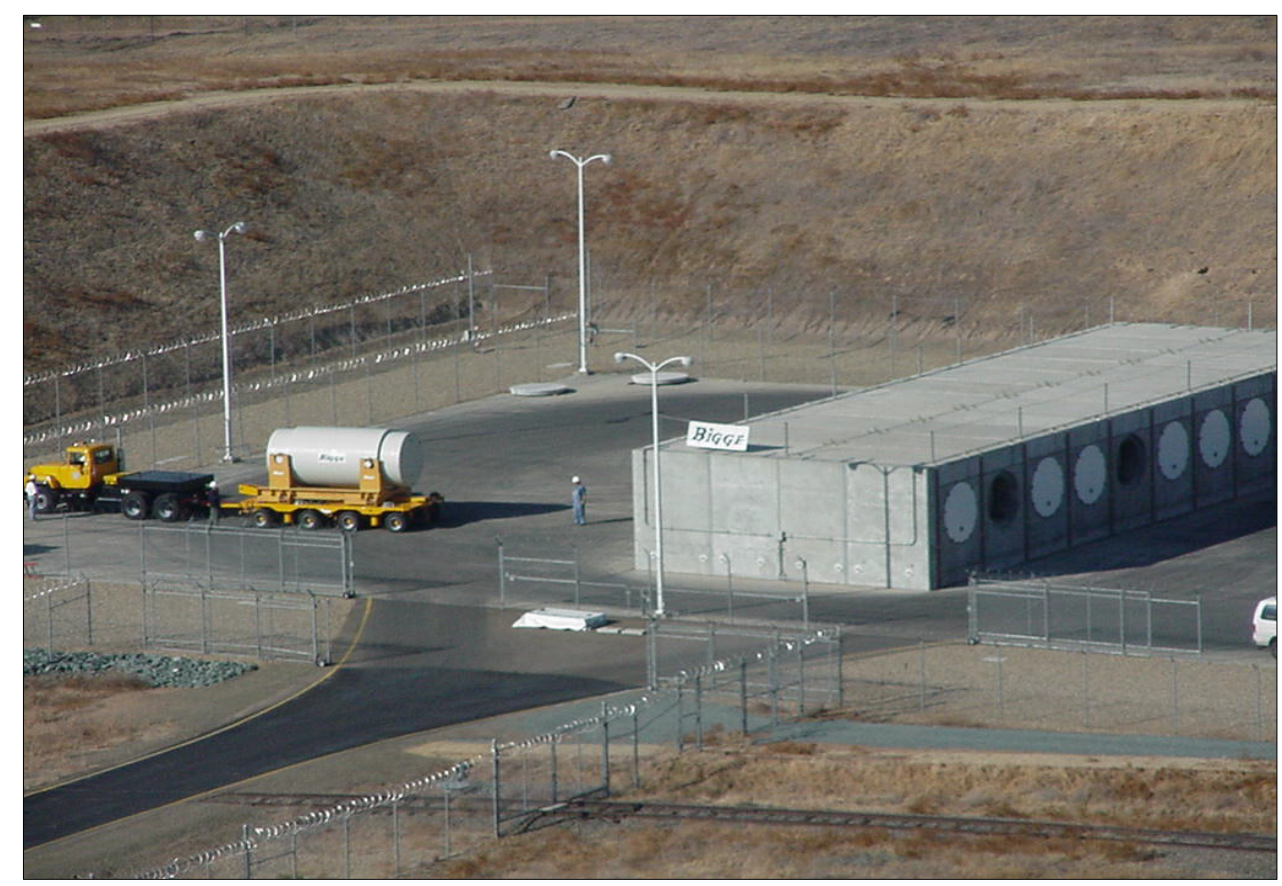

Figure A-3. Horizontal above ground spent fuel storage.

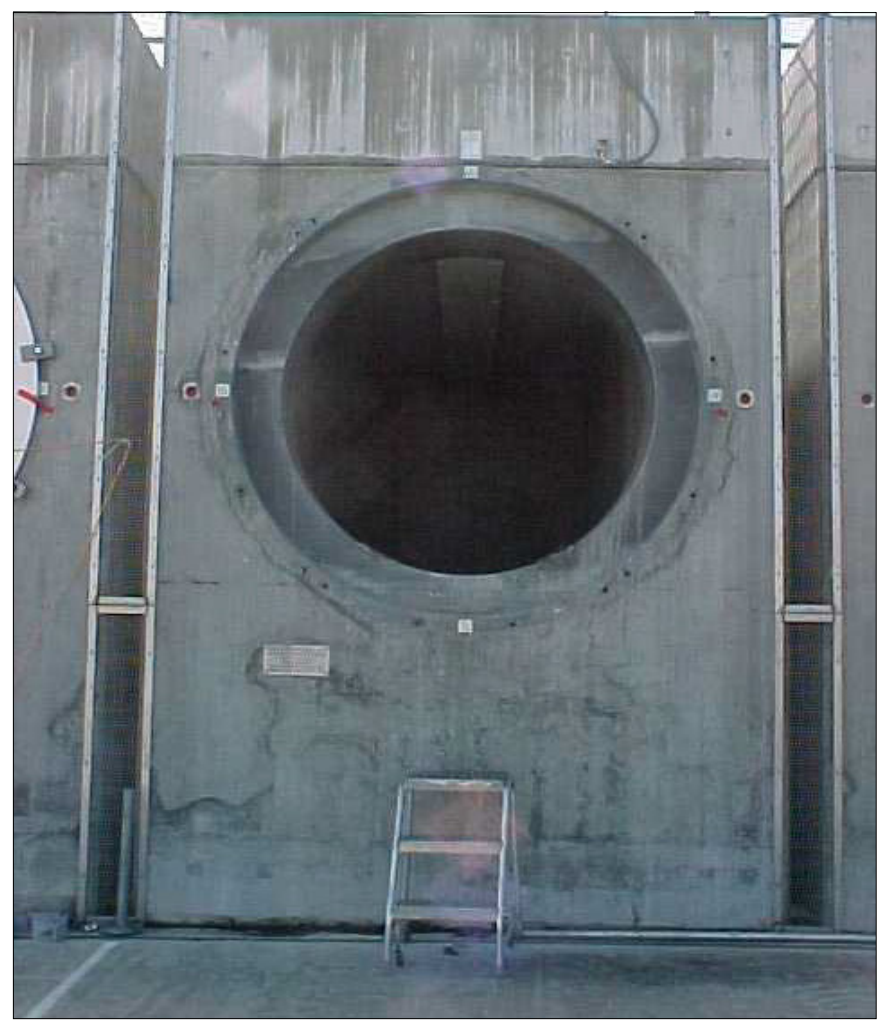

Figure A-4. Close up view of horizontal above ground spent fuel storage. 
Additional considerations and potential barriers for above ground storage include extensive seismic analysis and nuclear safety requirements.

For this alternative, the key factor is that establishing additional interim storage capacity would represent a significant capital expenditure without providing an actual solution to the permanent disposal of remote-handled LLW generated at INL beyond FY 2017 presenting an unacceptable risk that the mission need would be met.

Interim storage is not a credible option for meeting the mission need of establishing continued, uninterrupted, remote-handled LLW disposal capability for INL.

\section{A-2.4 Alternative 4-Storage for Decay}

This alternative can be defined as keeping the remote-handled LLW in storage either at the generator facilities or at another acceptable, safe location until disposal capacity is available. For storage for decay to be an effective alternative, the waste in question must be stored for a long enough period that its radioactive source term would decay to activity levels that could be more easily handled and meet lower limits on isotopic content. Theoretically, remote-handled LLW could be stored to allow the radioactivity to decay to levels where less restrictive waste acceptance criteria could be met and shipping requirements greatly simplified.

Although neither the ultimate disposal facility nor the future shipping and handling criteria are known, reasonable criteria can be established to assess the credibility of this scenario.

One reasonable criterion would be to assume decay until the waste qualified as contact-handled LLW. There is no single universal criterion for contact-handled LLW, but $200 \mathrm{mrem} /$ hour is a frequently used definition. This criterion is used to define remote-handled LLW in the DOE Programmatic Waste Management Environmental Impact Statement (EIS; DOE 1997), the Final Environmental Assessment (EA) for the Remote-handled Waste Disposition Project (DOE 2009), as well as to define remote-handled transuranic waste. The $200 \mathrm{mrem} /$ hour criteria is also the limit required by Department of Transportation for dose equivalent at the surface of shipping containers. Some simple calculations can be used to assess if it is practicable to store this waste for an effective decay period to reach $200 \mathrm{mrem} /$ hour. For example, Co-60 is the principal gamma emitter. It accounts for $14.3 \%$ of the total activity and nearly all of the gamma exposure in the nominal NRF radioisotopic waste inventory. No other gamma emitter accounts for even $0.2 \%$ of the source term (INL 2006).

The isotope Ni-63 accounts for $78.7 \%$ of the activity but is a pure beta emitter and, ignoring any contribution from Bremsstrahlung radiation, does not contribute to the external gamma exposure. The isotopes Fe-55 and Ni-59 account for 5.5 and $0.72 \%$ of the activity, respectively. However, these isotopes decay by electron capture and therefore do not contribute to the external gamma exposure. In the NRF inventory distribution, Co-60, with a 5.27-year half-life (Unterweger 2002), initially contributes virtually $100 \%$ of the external gamma exposure. Starting with an initial surface exposure rate of $30,000 \mathrm{R} /$ hour for the nominal maximum container, this waste would have to be stored for approximately 91 years to decay below the $200 \mathrm{mrem} /$ hour criteria for remote-handled LLW. Starting with an initial surface exposure rate of 11,000 R/hour for the average NRF remote-handled LLW container (Frazier 2008), this waste would have to be stored for approximately 83 years to decay below the $200 \mathrm{mrem} /$ hour criteria for remotehandled LLW. See Table A-1 for details of the exposure rate decay calculation. 
Table A-1. Decay calculations for time required to meet contact-handled exposure criterion.

\begin{tabular}{|c|c|c|c|c|c|c|c|}
\hline \multicolumn{8}{|c|}{ Assuming all external exposure due to Co-60 } \\
\hline $\begin{array}{l}\text { Decay } \\
\text { Time } \\
\text { in Years }\end{array}$ & $\begin{array}{l}\text { Exp in } \\
\mathrm{R} / \text { hour } \\
\text { (Maximum } \\
\text { Initial Dose) }\end{array}$ & $\begin{array}{l}\text { Multiples of } \\
200 \\
\mathrm{mR} / \text { hour }\end{array}$ & $\begin{array}{l}\text { Multiples of } \\
500 \\
\mathrm{mR} / \text { hour }\end{array}$ & $\begin{array}{l}\text { Exp in } \mathrm{R} / \mathrm{hr} \\
\text { (Average } \\
\text { Initial Dose) }\end{array}$ & $\begin{array}{l}\text { Multiples of } \\
200 \mathrm{mR} / \text { hour }\end{array}$ & $\begin{array}{l}\text { Multiples of } \\
500 \\
\mathrm{mR} / \text { hour }\end{array}$ & Note \\
\hline $\mathrm{T}=0$ & $3.00 \mathrm{E}+04$ & $1.50 \mathrm{E}+05$ & $6.00 \mathrm{E}+04$ & $1.10 \mathrm{E}+04$ & $5.50 \mathrm{E}+04$ & $2.20 \mathrm{E}+04$ & \\
\hline 1 & $2.63 \mathrm{E}+04$ & $1.32 \mathrm{E}+05$ & $5.26 \mathrm{E}+04$ & $9.64 \mathrm{E}+03$ & $4.82 \mathrm{E}+04$ & $1.93 \mathrm{E}+04$ & \\
\hline 2 & $2.31 \mathrm{E}+04$ & $1.15 \mathrm{E}+05$ & $4.61 \mathrm{E}+04$ & $8.46 \mathrm{E}+03$ & $4.23 \mathrm{E}+04$ & $1.69 \mathrm{E}+04$ & \\
\hline 5 & $1.55 \mathrm{E}+04$ & $7.77 \mathrm{E}+04$ & $3.11 \mathrm{E}+04$ & $5.70 \mathrm{E}+03$ & $2.85 \mathrm{E}+04$ & $1.14 \mathrm{E}+04$ & \\
\hline 6 & $1.36 \mathrm{E}+04$ & $6.82 \mathrm{E}+04$ & $2.73 \mathrm{E}+04$ & $5.00 \mathrm{E}+03$ & $2.50 \mathrm{E}+04$ & $1.00 \mathrm{E}+04$ & \\
\hline 10 & $8.06 \mathrm{E}+03$ & $4.03 \mathrm{E}+04$ & $1.61 \mathrm{E}+04$ & $2.95 \mathrm{E}+03$ & $1.48 \mathrm{E}+04$ & $5.91 \mathrm{E}+03$ & \\
\hline 15 & $4.17 \mathrm{E}+03$ & $2.09 \mathrm{E}+04$ & $8.35 \mathrm{E}+03$ & $1.53 \mathrm{E}+03$ & $7.65 \mathrm{E}+03$ & $3.06 \mathrm{E}+03$ & \\
\hline 25 & $1.12 \mathrm{E}+03$ & $5.61 \mathrm{E}+03$ & $2.24 \mathrm{E}+03$ & $4.11 \mathrm{E}+02$ & $2.06 \mathrm{E}+03$ & $8.22 \mathrm{E}+02$ & \\
\hline 50 & $4.19 \mathrm{E}+01$ & $2.09 \mathrm{E}+02$ & $8.38 \mathrm{E}+01$ & $1.54 \mathrm{E}+01$ & $7.68 \mathrm{E}+01$ & $3.07 \mathrm{E}+01$ & \\
\hline 76 & $1.37 \mathrm{E}+00$ & $6.86 \mathrm{E}+00$ & $2.75 \mathrm{E}+00$ & $5.03 \mathrm{E}-01$ & $2.52 \mathrm{E}+00$ & $1.01 \mathrm{E}+00$ & 1 \\
\hline 83 & $5.47 \mathrm{E}-01$ & $2.73 \mathrm{E}+00$ & $1.09 \mathrm{E}+00$ & $2.01 \mathrm{E}-01$ & $1.00 \mathrm{E}+00$ & $4.01 \mathrm{E}-01$ & 2 \\
\hline 84 & 4.79E-01 & $2.40 \mathrm{E}+00$ & $9.59 \mathrm{E}-01$ & $1.76 \mathrm{E}-01$ & 8.79E-01 & $3.52 \mathrm{E}-01$ & 3 \\
\hline 91 & $1.91 \mathrm{E}-01$ & $9.55 \mathrm{E}-01$ & $3.82 \mathrm{E}-01$ & $7.00 \mathrm{E}-02$ & $3.50 \mathrm{E}-01$ & $1.40 \mathrm{E}-01$ & 4 \\
\hline 100 & $5.85 \mathrm{E}-02$ & $2.93 \mathrm{E}-01$ & $1.17 \mathrm{E}-01$ & $2.15 \mathrm{E}-02$ & $1.07 \mathrm{E}-01$ & 4.29E-02 & \\
\hline \multicolumn{8}{|c|}{$\begin{array}{l}\text { Notes: (For interpretation of this table, assume } \mathrm{mR} \cong \text { mrem for gamma radiation.) } \\
\text { 1. Average NRF remote-handled LLW container (activated metals and resins) first meets } 500 \mathrm{mR} / \text { hour criterion. } \\
\text { 2. Average NRF remote-handled LLW container (activated metals and resins) first meets } 200 \mathrm{mR} / \text { hour criterion. } \\
\text { 3. Nominal maximum NRF remote-handled LLW container first meets } 500 \mathrm{mR} / \text { hour criterion. } \\
\text { 4. Nominal maximum NRF remote-handled LLW container first meets } 200 \mathrm{mR} / \text { hour criterion. }\end{array}$} \\
\hline
\end{tabular}

Because the RWMC utilized a $500 \mathrm{mrem} /$ hour criterion to distinguish remote-handled from contact-handled LLW, a case could be made for storing for decay until the waste reaches $500 \mathrm{mrem} /$ hour. Using the same calculation basis discussed above, starting with an initial surface exposure rate of $30,000 \mathrm{R} /$ hour for the nominal maximum container, this waste would have to be stored for approximately 84 years to decay below a $500 \mathrm{mrem} /$ hour criteria for remote-handled LLW. Starting with an initial surface exposure rate of 11,000 R/hour for the average NRF remote-handled LLW container, this waste would have to be stored for approximately 76 years to decay below the $500 \mathrm{mrem} / \mathrm{hour}$ criteria for remote-handled LLW.

All of these calculations assume that Bremsstrahlung radiation from Ni-63 can be ignored. Brehmsstrahlung radiation in this context refers to the $\mathrm{x}$-rays produced by shielding beta particles (electrons) with high " $z$ " materials. High " $z$ " shielding slows the beta radiation more quickly, resulting in more energetic x-rays. Because the excess shielding also shields the created $x$-rays, Brehmsstrahlung radiation can safely be ignored for this analysis. However, if it were a significant contributor to the external exposure, the required decay time would actually be longer because Ni-63 has a much longer half-life than Co-60. If this were not the case (i.e., Bremsstrahlung radiation from Ni-63 makes a significant contribution to external exposure), the decay period required would be even longer since Ni-63 has a half-life of 101 years, far longer than Co-60 (Collé et al. 2008).

Another option for establishing a criterion for a decay period exists, and that is the ability to meet the WAC for a specific waste disposal facility. Using Nevada National Security Site (NNSS) (formally 
known as the Nevada Test Site) as an example offsite disposal facility, the NRF inventory distribution was compared to the Appendix E Radionuclide Action Levels in the NNSS WAC (DOE/NV 2009). Below these action levels, LLW can be received at NNSS without the necessity of special performance assessments. Three radioisotopes in the nominal NRF inventory distribution, Ni-63, Co-60, and Nb-94, exceed the radionuclide action levels in the NNSS WAC. In order for radioactive decay to bring each of these isotopes below the respective action levels, the waste would have to be stored for 268 years for Ni63, 41 years for Co-60, and 53,000 years for Nb-94. Even if the waste were stored for sufficient time to bring the Ni- $63^{63}$ below its action level, a special performance assessment would still have to be completed for the $\mathrm{Nb}-94$.

Another possible criterion for determining a storage period for decay would be to look at the limits for shipping containers in 10 CFR Part 71, Appendix A. The $A_{2}$ limit for Ni-63 is given as $810 \mathrm{Ci} /$ container. Based on NRF projected waste inventories, 21,000 $\mathrm{Ci}$ of Ni-63 will be shipped in 13 shipments in 2018 (NRF 2010). This yields an average of 1,650 Ci/container for Ni-63, which is just over twice the $\mathrm{A}_{2}$ limit. Therefore, the average waste container would have to be stored for about one half-life of 101 years to meet the qualifying criterion for shipment in a Type A container. This is a conservative estimate since it looks only at Ni-63. Both Co-60 and Fe-55 also exceed their respective $\mathrm{A}_{2}$ criteria. Calculations using the sum of fractions rule would result in an actual storage period that would be longer. This analysis did not consider sizing the waste into smaller containers for shipment. The distribution uniformity of the isotopes within a candidate shipment is unknown as is the variation between candidate shipments. Furthermore, constraints on storage before shipping would limit the flexibility with which waste could be distributed among shipping containers. An assumption that the uniformity of the waste would always be sufficiently favorable to allow all shipments to be configured to meet the $\mathrm{A}_{2}$ limit for Ni-63 would be risky at best. In any case, this would only bring the Ni-63 below the $\mathrm{A}_{2}$ limit and would require a more detailed analysis to demonstrate compliance with the sum of the fractions rule.

Under any of the above criteria, storing the remote-handled waste for a sufficiently long period to open up simpler disposal options would require storing the waste for more than 75 years. As illustrated in this analysis, the half-lives of some of the isotopes of interest make it impractical to store this waste for an effective decay period. For example, Ni-63 is a significant contributor to the NRF activated metals waste stream and has a 101-year half-life. Another example is the isotope that contributes the majority of the gamma exposure, Co-60. While this isotope has a relatively short half-life, the decay storage time (over 75 years) is significant given the average initial exposure rate of $11,000 \mathrm{R} / \mathrm{hour}$.

The facilities and capacity do not exist to support this alternative. With no routine movement of waste out of the storage facility to a final disposal location, the INL would have to construct or otherwise find new storage capacity at least equivalent to the disposal capacity needed to meet the mission need for continuous disposal of remote-handled LLW. Construction of such a storage facility also would likely be more expensive than construction of a disposal facility, approximating the costs discussed above for Alternative 3-Interim Storage. The technical and functional requirements for retrievability of the waste packages, long-term structural integrity, and accessibility for inspection of the containers during the period of storage will add significant cost to the storage facility relative to a disposal facility.

There are several additional risks associated with pursuing this option. It may not be possible to ensure institutional control of the facility to the satisfaction of stakeholders. Furthermore, there is significant, unquantifiable risk that the assumed future, simpler waste disposal option may not materialize.

The strategy of storing for decay does not satisfy the mission need near-term, has a risk of creating a future orphan waste with a need for a disposal facility at some future time, has significantly greater costs, and provides no benefit. Therefore, storage for decay is not considered a credible alternative for disposition of remote-handled LLW generated at INL. 
For this alternative, the determinant factor is that while a physical facility to provide storage capacity for decay could be established, this option would represent a significant capital expenditure without providing an actual solution to the permanent disposal of remote-handled LLW generated at INL beyond FY 2017 presenting an unacceptable risk that the mission need would be met.

More detailed cost data and risk information have not been developed for this alternative because it is not considered a credible option for meeting the mission need of establishing continued, uninterrupted remote-handled LLW disposal capability for INL.

\section{A-2.5 Alternative 5-Development of an Onsite Remote-Handled Low-Level Waste Disposal Facility}

A new onsite disposal facility using a design based on the then current remote-handled LLW disposal practices in the SDA, would be developed as a new project, along with procurement of transport equipment and construction of required infrastructure. It is assumed that a facility could be sited, constructed, and operated at the INL. No disqualifying issues are apparent for development of a new onsite facility. Therefore, an analysis of the onsite disposal alternative focusing on design, construction, and operation of a new onsite remote-handled LLW disposal facility at the INL is carried forward for more detailed analysis. The specific location for such a disposal facility would be identified as part of project development concurrent with the requisite National Environmental Policy Act (NEPA) evaluation of remote-handled LLW disposal capability alternatives.

\section{A-2.6 Alternative 7-Privatization of Remote-Handled Low-Level Waste Disposal}

In an era of declining budgets, privatization has received much attention within the federal government. Through privatization, functions normally self-performed by DOE or one of its management and operations contractors are procured from commercial sources in a more cost-effective manner.

The alternative of privatization of INL remote-handled LLW disposal was identified in the Mission Need Statement and privatization is a reasonable alternative for consideration in establishing INL remote-handled LLW disposal capability. In general, privatization initiatives can be separated into three major types:

1. Contracting. This involves management and operations contractors subcontracting out specific tasks or DOE directly contracting for services previously provided by federal or management and operations employees. Contracting out can take many forms, from traditional service contracts to private financing and leaseback arrangements.

2. Divestiture of functions. This is the elimination of functions for which a federal role is no longer required. In divestiture, the government transfers an entire ongoing enterprise to private-sector control. Although the resulting private entity may still include the government as a customer, the focus and scope of the enterprise are likely to change.

3. Asset transfers. These involve sale or other transfer of real property or personal property. An asset sale, lease, or donation implies little or no government involvement after transfer.

The possibility of a new commercial facility that does not currently exist was briefly considered. The total project cost for site activities to dispose of INL and tenant-generated remote-handled LLW at a new offsite commercial facility would be similar to that estimated for offsite disposal at any offsite alternative due to shipping cask requirements and other activities necessary to support offsite shipment. 
However, life-cycle costs would be uncertain and difficult to compare with any degree of accuracy. No known facilities are planned to commence within the time of the project mission need.

The programmatic risks of speculating when, where, and whether such a facility would be placed in operation in time to support the mission need for uninterrupted disposal of INL and tenant-generated remote-handled LLW is simply too great to consider an unknown, new commercial facility as an option.

Alternatively, a combination of divestiture and asset transfer could be pursued for remote-handled LLW disposal. Under this scenario, a commercial entity would be solicited to fund the design, construction, and operation of a new remote-handled LLW disposal facility at INL. Due to the small volume of INL waste projected for the facility (i.e., an annual average of approximately $50 \mathrm{~m}^{3}$, or just over $4 \mathrm{~m}^{3}$ per month), a 'user-pays' cost recovery model would not be feasible for recovery of operating costs plus a return on investment. In order for a commercial entity to ensure recovery of the large capital outlay and ensure profitability of the disposal facility, the commercial entity would likely require that the facility accept remote-handled LLW from other non-INL generators (i.e., DOE and commercial) or expand disposal facility operations to other waste types. If the facility was limited to the INL's remote-handled LLW, the commercial entity would require a commitment from DOE to support operating costs independent of the waste volumes to be disposed. DOE's ability as a federal agency to commit future funds is constrained by the federal budget process, ruling out the likelihood of a durable long-term commitment.

Any commercial operation would require a return on its investment. Therefore, the costs for privatization would be higher. An undertaking of this nature would require a long term guarantee of DOE support to cover costs or availability of the site to other wastes generated offsite. Stakeholder acceptance of an expanded disposal facility scope would be very unlikely. In addition, such an expanded disposal facility would require regulation by the Nuclear Regulatory Commission (NRC), which would further complicate INL operations. Long-term liability and risks to DOE are also substantial and would require continued government control to mitigate such risks. A DOE report on privatization opportunities, entitled Harnessing the Market: The Opportunities and Challenges of Privatization, ${ }^{1}$ states:

The continuing success of a private activity should not be dependent on indefinite federal economic subsidization - that is, support in the form of reduced or no rent, transfer at less than fair market value, or continued presence on federal lands where such presence is not vital to the activity, in order to maintain private performance of the function.

While DOE has experienced actual savings from privatization efforts upwards of $25 \%$ (and in some cases higher), cost savings that could be realized through privatization of INL and tenant-generated remote-handled LLW disposal are unlikely to materialize, due to the low volume of INL remote-handled LLW and the low probability that wastes from other facilities would be able to be accepted at the facility to offset costs. Programmatic risks are great when speculating that a commercial facility will be placed in operation in time to support uninterrupted INL and tenant-generated remote-handled LLW disposal. Negotiations with commercial entities to develop such a service could be prolonged. If such capability were planned for and did not come to fruition, the resulting impacts to both nuclear energy and Naval Reactor missions would be substantial. Dependent nuclear energy and Naval Reactor operations would be significantly impacted pending establishment of alternate remote-handled LLW disposal capability. For these reasons, soliciting a commercial entity to design, construct, and operate a new onsite disposal facility at INL is not considered a credible alternative for establishing replacement remote-handled LLW disposal capability.

\footnotetext{
${ }^{1}$ http://www.osti.gov/privatization/report/report.htm.
} 
The determinant criteria for the privatization alternative are the high risk that, if pursued, the DOE could not complete the complex negotiations with private parties and it would not be able to overcome funding issues, regulatory hurdles, and stakeholder resistance in time to ensure that the mission need would be met on the required schedule. If such capability were planned for and did not come to fruition, the resulting impacts to both nuclear energy and Naval Reactor missions would be substantial.

Soliciting a commercial entity to design, construct, and operate a new onsite disposal facility at INL is not considered a credible alternative for establishing replacement remote-handled LLW disposal capability.

More detailed cost projections have not been developed for this alternative because it is not a credible option for meeting the mission need to establish continued, uninterrupted remote-handled LLW disposal capability for INL.

\section{A-2.7 Alternative 8-No Action}

The no action alternative consists of DOE conducting no activities to ensure uninterrupted, remote-handled LLW disposal capabilities for remote-handled LLW generated at INL. Under this alternative, remote-handled LLW would continue to be disposed of in the SDA until it is full or must be closed in preparation for final CERCLA closure. Individual generators could continue normal operations that result in generation of remote-handled LLW only until interim storage capacity was exhausted. At that time, operational activities that generate the subject waste would cease or be significantly curtailed because of a lack of disposal capability impacting mission critical activities.

\section{A-3. SCREENING AND ANALYSIS OF ONSITE ALTERNATIVES}

The previously discussed alternatives were analyzed relative to DOE Order 413.3B guidance criteria (DOE G 413.3-9, "U.S. Department of Energy Project Review Guide for Capital Asset Projects"). Only those criteria determined to be germane to these alternatives were selected for the screening analysis. These criteria are: risk, life cycle costs, complexity, stakeholder values, and regulatory compliance.

Alternative 5 was selected as the base case for the analysis because it represents the optimum means of achieving the mission need and provides a standard against which all other alternatives can be compared relative to risk, costs, complexity, stakeholder values, and regulatory compliance. The relative analysis of the alternatives against the criteria is reflected in Table A-2. In this manner, the alternatives are analyzed to identify that alternative that provides the best value to the government.

A detailed analysis of risks to support Table A-2 is captured in Table A-3. The risks from the Risk Management Plan for this project constitute the risks for the base case (Alternative 5) for comparison with the other alternatives. Without exception, the relative risks for the alternatives were higher than the base case.

Table A-4 provides the summary conclusions of the screening results (i.e., the most credible alternative). Because Alternative 5 is the only fully credible onsite alternative, it was selected for further detailed analysis. This analysis is presented in Section 1.2 of the Alternatives Analysis report. 
Table A-2. Onsite disposal facility screening against Department of Energy Guide 413.3-9 criteria.

\begin{tabular}{|c|c|c|c|c|c|}
\hline Alternative & Risk & Life-Cycle Costs & Complexity & $\begin{array}{c}\text { Stakeholder } \\
\text { Values }\end{array}$ & $\begin{array}{l}\text { Regulatory } \\
\text { Compliance }\end{array}$ \\
\hline $\begin{array}{l}\text { Alternative 5: } \\
\text { Build a new onsite } \\
\text { disposal facility }\end{array}$ & $\begin{array}{l}\text { Risks in Risk } \\
\text { Management Plan for } \\
\text { this alternative are } \\
\text { the base case. }\end{array}$ & $\begin{array}{l}\text { Between } \$ 158.4 \text { to } \\
\$ 238.4 \mathrm{M} \text {. }\end{array}$ & $\begin{array}{l}\text { DOE has full control. } \\
\text { No external agencies } \\
\text { involved. } \\
\text { No impact on site } \\
\text { operations. }\end{array}$ & $\begin{array}{l}\text { "Typical" Idaho } \\
\text { Resistance }\end{array}$ & $\begin{array}{l}\text { Straight forward - } \\
\text { no issues identified. }\end{array}$ \\
\hline $\begin{array}{l}\text { Alternative 1: } \\
\text { Continue disposal } \\
\text { at RWMC }\end{array}$ & $\begin{array}{l}\text { Increases risk to } \\
\text { schedule, resource } \\
\text { requirements, and } \\
\text { performance- } \\
\text { stakeholder and } \\
\text { regulatory issues. }\end{array}$ & $\begin{array}{l}\text { Greater than new onsite } \\
\text { disposal facility to } \\
\text { complete mission - } \\
\text { requires waste } \\
\text { excavation. } \\
\text { Addressing ROD and } \\
\text { stakeholders more than } \\
\text { offsets savings on } \\
\text { infrastructure. }\end{array}$ & $\begin{array}{l}\text { EPA and the State of } \\
\text { Idaho involved in } \\
\text { decision. } \\
\text { Disruption of } \\
\text { operations. }\end{array}$ & $\begin{array}{l}\text { Higher due to } \\
\text { perceived DOE } \\
\text { reversal on } \\
\text { commitment. }\end{array}$ & $\begin{array}{l}\text { Possible but requires } \\
\text { ROD amendment. } \\
\text { PA/CA and BRA } \\
\text { re-analysis required. } \\
\text { No space for facility } \\
\text { expansion. }\end{array}$ \\
\hline $\begin{array}{l}\text { Alternative 2: } \\
\text { Dispose at ICDF }\end{array}$ & $\begin{array}{l}\text { Increases risk to } \\
\text { schedule, resource } \\
\text { requirements, and } \\
\text { performance - } \\
\text { stakeholder, } \\
\text { regulatory, and } \\
\text { nuclear safety issues. }\end{array}$ & $\begin{array}{l}\text { Greater than new onsite } \\
\text { facility. } \\
\text { Addressing design, } \\
\text { ROD, nuclear safety, } \\
\text { and stakeholders more } \\
\text { than offsets savings on } \\
\text { infrastructure. }\end{array}$ & $\begin{array}{l}\text { EPA and the State of } \\
\text { Idaho involved in } \\
\text { decision. }\end{array}$ & $\begin{array}{l}\text { Higher due to } \\
\text { perceived DOE } \\
\text { change of } \\
\text { agreement. }\end{array}$ & $\begin{array}{l}\text { Possible but requires } \\
\text { ROD amendment. } \\
\text { Vault facility will } \\
\text { need to be } \\
\text { constructed. }\end{array}$ \\
\hline $\begin{array}{l}\text { Alternative 3: } \\
\text { Interim Storage }\end{array}$ & $\begin{array}{l}\text { Increases risk to } \\
\text { schedule, resource } \\
\text { requirements, and } \\
\text { performance- } \\
\text { stakeholder, higher } \\
\text { cost, design, and fails } \\
\text { to meet mission } \\
\text { need. }\end{array}$ & $\begin{array}{l}\text { Greater than new onsite } \\
\text { facility. } \\
\text { Enhanced design } \\
\text { requirements and } \\
\text { increased operations } \\
\text { costs. }\end{array}$ & $\begin{array}{l}\text { Naval Propulsion } \\
\text { Program involvement. } \\
\text { Disruption of } \\
\text { operations. }\end{array}$ & $\begin{array}{l}\text { Very high due to } \\
\text { lack of resolution } \\
\text { of disposal need. }\end{array}$ & $\begin{array}{l}\text { Issues probably } \\
\text { same as a new waste } \\
\text { storage facility. }\end{array}$ \\
\hline
\end{tabular}


Table A-2. (continued).

\begin{tabular}{|c|c|c|c|c|c|}
\hline Alternative & Risk & Life-Cycle Costs & Complexity & $\begin{array}{c}\text { Stakeholder } \\
\text { Values }\end{array}$ & $\begin{array}{l}\text { Regulatory } \\
\text { Compliance }\end{array}$ \\
\hline $\begin{array}{l}\text { Alternative 4: } \\
\text { Storage for decay }\end{array}$ & $\begin{array}{l}\text { Increases risk to } \\
\text { schedule, resource } \\
\text { requirements, and } \\
\text { performance- } \\
\text { stakeholder, higher } \\
\text { cost, design, and fails } \\
\text { to meet mission need. }\end{array}$ & $\begin{array}{l}\text { Greater than new onsite } \\
\text { facility. } \\
\text { Enhanced design } \\
\text { requirements and } \\
\text { increased operations } \\
\text { costs. }\end{array}$ & $\begin{array}{l}\text { Naval Propulsion } \\
\text { Program involvement. } \\
\text { Disruption of } \\
\text { operations. } \\
\text { Inordinately long term } \\
\text { operational } \\
\text { requirements. }\end{array}$ & $\begin{array}{l}\text { Very high due to } \\
\text { lack of resolution } \\
\text { of disposal need. }\end{array}$ & $\begin{array}{l}\text { Issues probably } \\
\text { same as a new waste } \\
\text { storage facility. }\end{array}$ \\
\hline $\begin{array}{l}\text { Alternative 7: } \\
\text { Privatization }\end{array}$ & $\begin{array}{l}\text { Increases risk to } \\
\text { schedule, resource } \\
\text { requirements, and } \\
\text { performance-- } \\
\text { stakeholder, higher } \\
\text { cost, design, and fails } \\
\text { to meet mission need. }\end{array}$ & $\begin{array}{l}\text { Greater than new onsite } \\
\text { facility if allocated only } \\
\text { to remote-handled } \\
\text { LLW disposal. }\end{array}$ & $\begin{array}{l}\text { External vendor } \\
\text { involvement. } \\
\text { NRC involvement. }\end{array}$ & $\begin{array}{l}\text { Very high if } \\
\text { solution includes } \\
\text { receipt of added } \\
\text { wastes from } \\
\text { offsite. }\end{array}$ & $\begin{array}{l}\text { Complicated if } \\
\text { offsite waste to be } \\
\text { accepted. }\end{array}$ \\
\hline $\begin{array}{l}\text { Alternative 8: } \\
\text { No Action }\end{array}$ & $\begin{array}{l}\text { Certainty of failure to } \\
\text { meet mission need. }\end{array}$ & NA & $\mathrm{NA}$ & $\begin{array}{l}\text { Very high due to } \\
\text { lack of resolution } \\
\text { of disposal need. }\end{array}$ & $\begin{array}{l}\text { Technically } \\
\text { compliant since } \\
\text { current activities are } \\
\text { compliant. }\end{array}$ \\
\hline \multicolumn{6}{|c|}{$\begin{array}{l}\text { Definitions: } \\
\text { 1. Risk - Can the alternative eliminate or minimize risks? Risks are defined as events that negatively impact schedule, resources or performance of the project. } \\
\text { 2. Life Cycle Cost - The sum total of the direct, indirect, recurring, nonrecurring, and other related costs incurred or estimated to be incurred in the design, development, } \\
\text { production, operation, maintenance, support, and final disposition of a major system over its anticipated useful life span. Where the alternative anticipates use of } \\
\text { existing sites or facilities, consideration of restoration and refurbishment costs is included. } \\
\text { 3. Complexity - Can the alternative be achieved with minimal coordination with external agencies or vendors and minimal interference with INL or tenant operations? } \\
\text { 4. Stakeholder values - Can the alternative gain the appropriate level of approval from key stakeholders? } \\
\text { 5. Regulatory Compliance - Can the alternative be executed in compliance with regulatory approvals and requirements? }\end{array}$} \\
\hline
\end{tabular}


Table A-3. Relative risk results of onsite remote-handled low-level waste disposal alternatives.

\begin{tabular}{|c|c|c|c|}
\hline Alternative & Schedule $^{\mathrm{a}}$ & Resources $^{\mathrm{b}}$ & Performance $^{c}$ \\
\hline \multirow{7}{*}{$\begin{array}{l}\text { Alternative 5: } \\
\text { Build a new onsite } \\
\text { disposal facility }\end{array}$} & $\begin{array}{l}\text { Schedule could be adversely impacted } \\
\text { by: }\end{array}$ & $\begin{array}{l}\text { Resource requirements could be } \\
\text { increased by: }\end{array}$ & $\begin{array}{l}\text { Performance could be adversely } \\
\text { affected by: }\end{array}$ \\
\hline & 1. Design changes & Design changes & 1. Design conflicts \\
\hline & 2. Funding shortfall & 1. Stakeholder resistance & 2. Stakeholder resistance \\
\hline & 3. Stakeholder resistance & 2. No FONSI in EA & 3. No FONSI in EA \\
\hline & $\begin{array}{l}\text { 4. No Finding of No Significant } \\
\text { Impact (FONSI) in EA }\end{array}$ & 3. Site disqualification. & 4. Site disqualifications. \\
\hline & $\begin{array}{l}\text { 5. Delays with nuclear safety } \\
\text { documentation }\end{array}$ & & \\
\hline & 6. Site disqualification. & & \\
\hline \multirow{6}{*}{$\begin{array}{l}\text { Alternative 1: } \\
\text { Continue disposal at } \\
\text { RWMC }\end{array}$} & Relative to Alternative 5: & Relative to Alternative 5: & Relative to Alternative 5: \\
\hline & No change to risks $1,2,5$, and 6 . & No change to risks 7 and 10 . & No change to risk 11 . \\
\hline & May decrease risk 4. & May decrease risk 9. & May decrease risk 13. \\
\hline & Certain increase to risk 3 . & Certain increase to risk 8 . & Certain increase to risk 12 . Certain \\
\hline & $\begin{array}{l}\text { Adds risk due to changing existing } \\
\text { regulatory agreements. }\end{array}$ & $\begin{array}{l}\text { Adds risk due to changing existing } \\
\text { regulatory agreements. }\end{array}$ & $\begin{array}{l}\text { increase to risk } 14 \text {, No room for } \\
\text { facility expansion. }\end{array}$ \\
\hline & & & $\begin{array}{l}\text { Adds risk due to changing existing } \\
\text { regulatory agreements. }\end{array}$ \\
\hline \multirow{5}{*}{$\begin{array}{l}\text { Alternative 2: } \\
\text { Dispose at ICDF } \\
\text { Assume facility } \\
\text { expansion }\end{array}$} & Relative to Alternative 5: & Relative to Alternative 5: & Relative to Alternative 5: \\
\hline & No change to risks 1,2 , and 6 . & No change to risk 10 . & No change to risks 11 and 14 . \\
\hline & May increase risk 4. & May increase risks 7 and 9. & May increase risk 13. \\
\hline & Certain increase to risk 3 and 5. & Certain increase to risk 8 . & Certain increase to risk 12 . \\
\hline & $\begin{array}{l}\text { Adds risk due to changing existing } \\
\text { regulatory agreements. }\end{array}$ & $\begin{array}{l}\text { Adds risk due to affecting design } \\
\text { and changing existing regulatory } \\
\text { agreements. }\end{array}$ & $\begin{array}{l}\text { Adds risk due to changing existing } \\
\text { regulatory agreements. }\end{array}$ \\
\hline
\end{tabular}


Table A-3. (continued).

\begin{tabular}{|c|c|c|c|}
\hline Alternative & Schedule $^{\mathrm{a}}$ & Resources $^{\mathrm{b}}$ & Performance $^{c}$ \\
\hline Alternative 3: & Relative to Alternative 5: & Relative to Alternative 5: & Relative to Alternative 5: \\
\hline Interim Storage & No change to 4 and 6 . & No change to 9 and 10. & No change to 13 and 14. \\
\hline $\begin{array}{l}\text { Assume new facility } \\
\text { with enhanced } \\
\text { engineering design and } \\
\text { accessibility to waste. }\end{array}$ & Certain increase to risk $1,2,3$, and 5 . & Certain increase to risk 7 and 8. & $\begin{array}{l}\text { Certain increase to risk } 11 \text { and } 12 . \\
\text { Increases risk; insufficient to satisfy } \\
\text { mission need on its own. }\end{array}$ \\
\hline Alternative 4: & Relative to Alternative 5: & Relative to Alternative 5: & Relative to Alternative 5: \\
\hline Storage for decay & No change to 4 and 6 . & No change to 9 and 10. & No change to 13 and 14. \\
\hline $\begin{array}{l}\text { Assume new facility } \\
\text { with enhanced } \\
\text { engineering design, } \\
\text { longer design life, and } \\
\text { accessibility to waste. }\end{array}$ & Certain increase to risk $1,2,3$, and 5 . & Certain increase to risk 7 and 8. & $\begin{array}{l}\text { Certain increase to risk } 11 \text { and } 12 . \\
\text { Increases risk; insufficient to satisfy } \\
\text { mission need on its own. }\end{array}$ \\
\hline $\begin{array}{ll}\text { a. } & \text { Events that could adversely } \\
\text { b. Events that could adversely } \\
\text { c. } & \text { Events that could adversely }\end{array}$ & $\begin{array}{l}\text { mpact the ability to complete the project on the } \\
\text { mpact the resources required to complete the pr } \\
\text { mpact the ability to complete the project success }\end{array}$ & $\begin{array}{l}\text { uired schedule. } \\
\text { t. } \\
\text { ly and fulfill the mission need. }\end{array}$ & \\
\hline
\end{tabular}


Table A-4. Summary of screening results of remote-handled low-level waste onsite disposal alternatives.

\begin{tabular}{|c|c|c|}
\hline Disposal Alternative & Credible? & Summary Rationale for Credibility Conclusion \\
\hline $\begin{array}{l}\text { Alternative 1: } \\
\text { Continued Disposal at } \\
\text { RWMC }\end{array}$ & No & $\begin{array}{l}\text { The option to not close the RWMC cannot be implemented because the CERCLA no action } \\
\text { alternative for this facility has already been rejected as not meeting the threshold criteria of } \\
\text { protecting human health and the environment. Continuing operation of the remote-handled } \\
\text { LLW disposal pits while permanently closing the remainder of the facility is not feasible given } \\
\text { the facility configuration. This alternative is not available to meet the mission need. }\end{array}$ \\
\hline $\begin{array}{l}\text { Alternative 2: } \\
\text { Disposal at ICDF }\end{array}$ & No & $\begin{array}{l}\text { Disposing of remote-handled LLW at the ICDF would face severe obstacles in terms of } \\
\text { obtaining regulatory approvals, conflicting design objectives with the existing cells, and } \\
\text { possible conflict with the main mission of the ICDF - consolidation and disposal of all INL } \\
\text { CERCLA waste. The likelihood of obtaining all necessary approvals to expand the ICDF WAC } \\
\text { to accept remote-handled LLW is extremely low and the risk that this alternative could not be } \\
\text { implemented in time meet the mission need by } 2017 \text {, if ever, is too great to consider this a } \\
\text { credible alternative. }\end{array}$ \\
\hline $\begin{array}{l}\text { Alternative 3: } \\
\text { Interim Storage }\end{array}$ & No & $\begin{array}{l}\text { The generator facilities have very limited storage capacity available and there are no plans to } \\
\text { expand interim storage capability at NRF or ATR. Additionally, there are no other existing or } \\
\text { planned facilities onsite to which the remote-handled LLW could be transferred for interim } \\
\text { storage without significant capital and operational investment. This option would represent a } \\
\text { significant capital expenditure without providing an actual solution to meeting the mission } \\
\text { need of providing for permanent disposal of remote-handled LLW generated at INL beyond } \\
\text { FY } 2017 \text { and is not considered a credible alternative. }\end{array}$ \\
\hline $\begin{array}{l}\text { Alternative 4: } \\
\text { Storage for Decay }\end{array}$ & No & $\begin{array}{l}\text { Starting with an initial surface exposure rate of } 11,000 \text { R/hour for an average NRF remote- } \\
\text { handled LLW container, this waste would have to be stored for over } 80 \text { years to decay below } \\
\text { the } 200 \mathrm{mR} / \text { hour criteria for remote-handled LLW. As discussed for the Storage for Decay } \\
\text { option, the facilities do not exist onsite for this storage. Providing this storage would require } \\
\text { INL to construct or otherwise find new storage capacity at least equivalent to the disposal } \\
\text { capacity needed to meet the mission need for continuous disposal of remote-handled LLW. } \\
\text { Therefore, storage for decay is not considered a credible alternative for remote-handled LLW } \\
\text { generated at INL. }\end{array}$ \\
\hline
\end{tabular}


Table A-4. (continued).

\begin{tabular}{|c|c|c|}
\hline Disposal Alternative & Credible? & Summary Rationale for Credibility Conclusion \\
\hline $\begin{array}{l}\text { Alternative 5: } \\
\text { Design, Construct, and } \\
\text { Operate a New Onsite } \\
\text { Remote-Handled LLW } \\
\text { Disposal Facility }\end{array}$ & Yes & $\begin{array}{l}\text { This alternative was found to be a credible candidate for further analysis because essentially } \\
\text { the same activities are already being performed onsite. Risks of implementing this alternative } \\
\text { are minimal since the disposal facility design uses current practices and equipment. Long-term } \\
\text { impacts and stakeholder objections can be mitigated through design, operating, monitoring, and } \\
\text { closure standards. The risks of siting, construction, and operation are generally within DOE } \\
\text { control. Costs can be estimated within a reasonable range of uncertainty and no completely } \\
\text { disqualifying characteristics are known. }\end{array}$ \\
\hline $\begin{array}{l}\text { Alternative 7: } \\
\text { Privatization }\end{array}$ & No & $\begin{array}{l}\text { Complex negotiations, regulatory hurdles, stakeholder resistance to offsite waste receipt, } \\
\text { continuing DOE liability, and poor economic viability without long term DOE guarantees } \\
\text { make this a very high risk alternative with poor to no likelihood of meeting the mission need } \\
\text { on the required schedule. }\end{array}$ \\
\hline $\begin{array}{l}\text { Alternative 8: } \\
\text { No Action }\end{array}$ & No & $\begin{array}{l}\text { Fails to meet mission need with severe implications for critical nuclear energy and national } \\
\text { security missions. }\end{array}$ \\
\hline
\end{tabular}




\section{A-4. DETAILED ANALYSIS OF THE NEW REMOTE-HANDLED LOW-LEVEL WASTE ONSITE FACILITY DISPOSAL ALTERNATIVE}

This section provides further detailed evaluation of the most credible onsite disposal option for the INL remote-handled LLW.

\section{A-4.1 Assumptions and Strategies}

The approach taken was to use existing information from the ICDF project with modifications to cost and schedule to reflect the current projected waste volumes for remote-handled LLW, NEPA regulations (42 USC $\S 4321$ et seq.) versus CERCLA regulations (42 USC $\S 9601$ et seq.), safety analysis assumptions for a Hazard Category 2 facility, and historical remote-handled LLW disposal at RWMC. The following assumptions and strategies were used to develop the cost and schedule for the new onsite remote-handled LLW disposal facility:

- The facility will be a Hazard Category 2 facility based on the total radionuclide inventory.

- Costs for remote-handled LLW vaults are based on actual costs for the construction of new disposal vaults at RWMC between 2001 and 2003.

- Although the vault design assumptions do not meet RCRA Subtitle $\mathrm{C}$ liner requirements for mixed LLW, the design includes engineered features that take into account operational impacts and are protective of groundwater.

- The use of removable concrete covers for the remote-handled LLW vaults will likely simplify the cover design relative to that required over the cells.

- The remote-handled LLW can be handled in a similar manner as it is today at the SDA. A crane and support equipment are used to move the cask over the top of the vault, lower the liner into the vault, and seal the vault.

- An EA, not an EIS, will be prepared to comply with NEPA. The EA will tier from the analyses and decisions made in the 1995 INL EIS on environmental restoration and waste management (DOE 1995).

- Operational costs associated with the SDA pit and vaults were used for estimating purposes.

- A 30\% management reserve was applied and should cover any additional costs related to reasonable enhancements instituted as best management practices.

- No costs for changes in infrastructure for shipping, packaging, and temporary storage are anticipated to be needed in order to achieve onsite disposal of remote-handled LLW.

The following actions or approvals are needed from DOE, per the schedules in Appendix C, to implement this alternative:

- $\quad$ CD-1 through CD-4 for an onsite LLW landfill

- EA determination and FONSI based on the EA for the Remote-Handled LLW Disposal Project

- Operational readiness review. 


\section{A-4.2 Costs}

The costs for onsite disposal were estimated for a new onsite disposal facility using a design based on the remote-handled LLW disposal practices in the SDA. Existing information from ICDF and RWMC, with cost and schedule modifications to reflect projected remote-handled LLW waste volumes, applicable regulations, and safety analysis assumptions for a Hazard Category 2 nuclear facility, were used for the analysis. A 20 -year operating life was assumed. The costs for developing a new remote-handled LLW disposal facility included siting, design, and construction of infrastructure; acquisition of a cask and new liner handling equipment; maintenance of disposal authorization and safety documentation; project management; operations; and closure. Costs are escalated and include an appropriate management reserve. Operational costs associated with the SDA vaults were used for estimating purposes. A management reserve was applied and should cover any additional costs related to reasonable enhancements instituted as best management practices. Costs for the onsite disposal facility construction, operation, and closure through the year 2038 are between $\$ 158.4$ and $\$ 238.4 \mathrm{M}$.

Overall risk for this alternative is considered low because the risks involved with siting, construction, and operation are largely under the control of DOE and do not involve out-of-state transport. The facility will be designed using experience, practices, and materials, which introduce little design risk. The potential risk of long-term impacts to the aquifer can be mitigated through use of design, operating, monitoring, and closure standards. Environmental risks of onsite disposal are mitigated by the absence of exposed waste, minimal contamination involved with activated metals, and the more robust containment provided by a vault system in comparison to pit disposal operations.

The possibility of public perception, necessitating an otherwise unnecessary liner, is a significant risk. Neither DOE Order 435.1 nor 10 Code of Federal Regulations (CFR) 61 requires engineered or clay liners for LLW land disposal. These RCRA-type liners are traditionally not used for LLW disposal facilities because, since development of 10 CFR 61, the concept of "controlled release" has been understood to be an effective approach for managing LLW disposal. In reference to 10 CFR 61.51, Disposal Site Design, item (6), the Final EIS on 10 CFR 61, NUREG-0945, Vol. 1, p. 5-14, states that allowing for some leakage is actually desirable:

Reducing the contact time of water with the waste by using freely draining granular backfill should be considered. In addition, the accumulation of water in the disposal unit (the bathtub effect) must be avoided. This can normally be accomplished if the bottom of the disposal unit can drain at least as readily as water can infiltrate into the disposal unit through the cover or sides....

Relying on an engineered or clay liner also contradicts a technical requirement in 10 CFR 61 to not become dependent on a design feature that could require long-term maintenance. Specifically, in the original Federal Register notification for 10 CFR 61 (47 FR 57450), the first paragraph states:

The Commission takes exception to any design which relies on a leachate collection and treatment system to reduce migration. Such a design is expected to result in a requirement for continued active site maintenance, therefore violating the performance objective in [10 CFR Part] 61.44. 
Based on these considerations and factors specific to the INL Site and the characteristics of the waste streams being disposed, there is no reason to include a liner for the remote-handled LLW facility design, and including the liner in the design is more likely to degrade performance than it is to improve it.

If planned funding is not available, impact to proposed schedule could require development of interim storage for remote-handled LLW at an onsite facility.

\section{A-4.3 Complexity}

This alternative involves just one facility. Because all shipments occur within site boundaries, existing transport practices can be used. This completely eliminates the costs, risks, and schedule impacts of development of a new offsite transportation cask system and simplifies the coordination and management of shipments.

\section{A-4.4 Stakeholder Values}

A proposal to develop a new onsite waste disposal facility would likely generate some stakeholder response. Stakeholder concerns would be expected to include siting, especially if the facility is located near ICDF; concerns that a new INL facility would be made available for disposal of waste from offsite; and protection of the Snake River Plain Aquifer. Stakeholders will have involvement through the NEPA process and other established public and regulator forums, as appropriate.

If the alternative of a new facility is selected, stakeholder concerns about location can be addressed via the site selection criteria used in the facility siting assessment. Stakeholders also have expressed concerns that a new INL facility would be made available for disposal of waste from offsite; however, use of INL for offsite waste disposal is not a decision DOE has made pursuant to NEPA. INL is restricted to disposal of LLW from onsite only based on DOE's ROD for LLW (DOE 2000). Concerns for protection of the aquifer have been paramount and therefore, stakeholder reactions to disposal of LLW onsite could be mixed.

\section{A-4.5 Regulatory Compliance}

No regulatory compliance issues identified.

\section{A-5. CONCLUSION}

The design, construction, and operation of a new onsite facility for the disposal of remote-handled LLW are the only credible onsite alternative for establishing continued, uninterrupted remote-handled LLW disposal capability for INL. Risks of implementing this alternative are minimal since the disposal facility design uses current practices and equipment. Long-term impacts and stakeholder objections can be mitigated through design, operating, monitoring, and closure standards. No changes to existing regulatory compliance agreements are required to implement this alternative. The risks of siting, construction, and operation are generally within DOE control. Costs can be estimated within a reasonable range of uncertainty and no completely disqualifying characteristics are known. 


\section{A-6. REFERENCES}

10 CFR 61, 2002, Title 10, "Energy," Part 61, "Licensing Requirements for Land Disposal of Radioactive Waste," Code of Federal Regulations, Office of the Federal Register.

15 USC $§ 2601$ et seq., “Toxic Substances Control Act,” United States Code.

42 USC § 4321 et seq., 1970, "National Environmental Policy Act," United States Code, January 1, 1970.

42 USC § 9601 et seq., 1980, “Comprehensive Environmental Response, Compensation and Liability Act of 1980 (CERCLA/Superfund)," United States Code, December 11, 1980.

47 FR 57450, Federal Register Notification for 10 CFR 61.

Collé R., B. E. Zimmerman, P. Cassette, and L. Laureano-Perez, 2008, “63 Ni, Its Half-life and Standardization: Revisited," Applied Radiation and Isotopes, 66 (1), pp. 60-68.

DOE, 1995, Programmatic Spent Nuclear Fuel Management and Idaho National Engineering Laboratory Environmental Restoration and Waste Management Programs Final Environmental Impact Statement, DOE/EIS-203-F, U.S. Department of Energy, Office of Environmental Management, August 1995.

DOE, 1997, DOE Programmatic Waste Management EIS, DOE/EIS-0200-F, U.S. Department of Energy, May 1997.

DOE, 2000, “Record of Decision for the Department of Energy's Waste Management Program: Treatment and Disposal of Low-Level Waste and Mixed Low-Level Waste; Amendment to the Record of Decision for the Nevada Test Site," 65 Federal Register 10061, February 25, 2000.

DOE, 2009, Final Environmental Assessment for the Remote-handled Waste Disposition Project, DOE/EA-01386, U.S. Department of Energy, Office of Environmental Management, February 2009.

DOE-ID, 1991, Federal Facility Agreement and Consent Order for the Idaho National Engineering Laboratory, Administrative Record No. 1088-06-29-120, U.S. Department of Energy Operations Office; U.S. Environmental Protection Agency, Region 10; Idaho Department of Health and Welfare, December 4, 1991.

DOE-ID, 1999, Final Record of Decision: Idaho Nuclear Technology and Engineering Center: Operable Unit 3-13, DOE/ID-10660, Rev. 0, Idaho National Laboratory, October 1999.

DOE-ID, 2007a, Proposed Plan for Radioactive Waste Management Complex Operable Unit 7-13/14, DOE/ID-11288, Rev. 00, October 17, 2007.

DOE-ID, 2007b, ICDF Complex Waste Acceptance Criteria, DOE/ID-10881, Rev. 4, Idaho National Laboratory, July 2007.

DOE-ID, 2008, Record of Decision for Radioactive Waste Management Complex Operable Unit 7-13/14, DOE/ID-11359, Rev. 0, September 2008. 
DOE-NV, 1999, Agreement in Principal Between the Department of Energy and the State of Nevada, DE-GM08-99NV13571, June 1999.

DOE Guide 413.3-9, 2008, US Department of Energy Project Review Guide for Capital Asset Projects, U.S. Department of Energy, September 23, 2008.

DOE Order 413.3B, 2006, "Program and Project Management for Acquisition of Capital Assets," U.S. Department of Energy, July 28, 2006.

DOE Order 435.1, 2001, "Radioactive Waste Management," U.S. Department of Energy, August 28, 2001.

Frazier, 2008, E-Mail from Jeff Frazier to Joan Connolly, "Subject: Revised Alternatives Analysis for RH LLW Disposal," July 28, 2010.

INL, 2006, Low-Level Waste Disposal Alternatives Analysis Report, INL/EXT-06-11601, Revision 1, Idaho National Laboratory, Idaho Falls, Idaho, September 2006.

NRF, 2010, Letter to L.A. Harvego, INL, "Subject: Long Range Radioactivity estimate for NRF RHLLW,"NRF-WS-473, March 2010.

Unterweger, M. P., 2002, "Half-life measurements results at the National Institute of Standards and Technology," Proc. Tenth ICRM meeting, Applied Radiation and Isotopes, 56, pp. 125-130. 
A-26 


\section{Appendix B}

\section{Details of Evaluation of Offsite Alternatives for Remote-Handled Low-Level Waste Disposal}


B-2 


\section{Appendix B}

\section{Details of Evaluation of Offsite Alternatives for Remote-Handled Low-Level Waste Disposal}

\section{B-1. INTRODUCTION}

This appendix presents the detailed evaluation of Alternative 6, offsite remote-handled low-level waste (LLW) disposal (multiple locations). Eight offsite disposal facility candidates were identified that represent both Department of Energy (DOE) and commercial disposal capabilities. The key criteria for this evaluation are described in Section 1.3 of the Alternatives Analysis report.

Each candidate offsite disposal facility is evaluated for their ability to accept Idaho National Laboratory (INL) remote-handled LLW resin and activated metal waste streams for disposal. Candidate facilities are identified and screened using costs, risk, complexity, stakeholder values, and regulatory compliance. Further detailed analysis of the selected offsite also was performed.

\section{B-2. DESCRIPTION OF OFFSITE FACILITIES FOR EVALUATION}

Candidate facilities for offsite disposal were identified through literature searches and contacts with disposal facility representatives. Each candidate facility is described and subjected to screening criteria (i.e., risk, life-cycle cost, complexity, stakeholder values, and regulatory compliance). As a result of this process, one facility was selected for further review based on its credibility to meet the mission need and was assessed in further detail.

\section{B-2.1 EnergySolutions}

The EnergySolutions facility in Clive, Utah is located in Tooele County. The State of Utah administers the Nuclear Regulatory Commission (NRC) program for facility licensing in Utah. The existing license was renewed on September 8, 2009, and expires January 25, 2013. The facility can accept only the lowest classifications of LLW under its radioactive materials license. The INL's remote-handled resins exceed this facility waste acceptance criteria (WAC) relative to $\mathrm{Cs}^{137}, \mathrm{Sr}^{90}$, and $\mathrm{Tc}^{99}$. Likewise, INL remote-handled activated metals waste streams will not meet the facility WAC. Therefore, this facility cannot accept

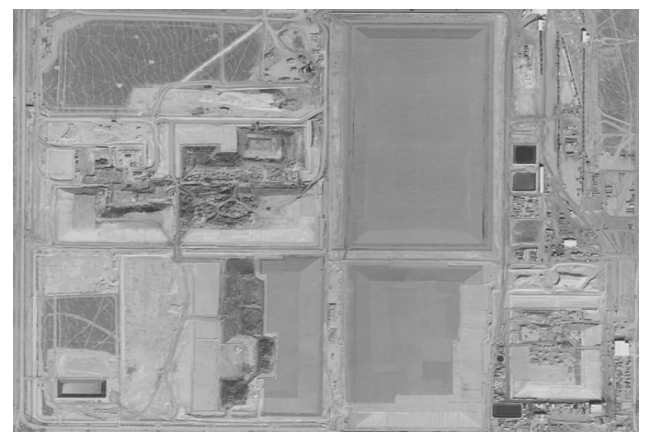
any of the INL remote-handled LLW at this time or in the foreseeable future. 


\section{B-2.2 U.S. Ecology}

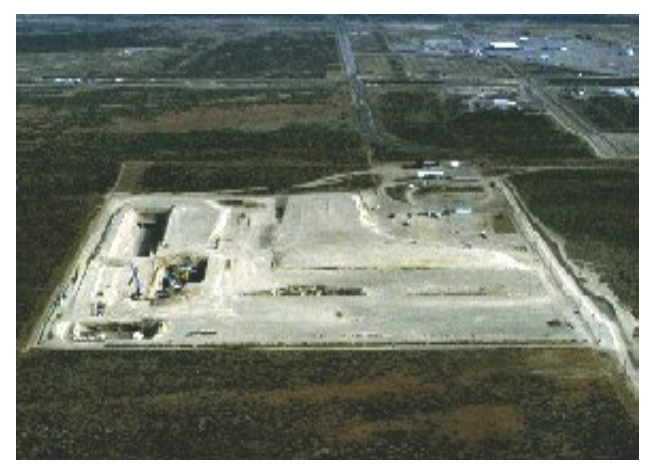

U.S Ecology is located on 100 acres of land at the DOE Hanford site that are leased by the State of Washington from DOE. The facility can accept a broad range of LLW. The State of Washington administers the NRC program for facility licensing in Washington. The existing license is valid through 2011. To date, the facility has received over $13,500,000 \mathrm{ft}^{3}$ of LLW and it has a remaining capacity of approximately $44,000,000 \mathrm{ft}^{3}$. This disposal facility is for Northwest and Rocky Mountain Compact states. Disposal of LLW that is the responsibility of the federal government is subject to state approval. To date, no such approval has been sought for DOE waste. The facility can accept a broad range of LLW; however, some of the INL's remote-handled LLW with high radiation levels would challenge the waste acceptance criteria. Not all of the INL's remote-handled LLW activated metals waste meets the facility WAC.

U.S. Ecology has not received DOE waste to date, and they would need to open dialogue with the State of Washington to reach agreement on the acceptance of the waste. Given the repeated efforts by the State of Washington to prevent offsite waste from going to Hanford, any proposal to receive DOE waste at U.S. Ecology could be met with significant resistance from the state and other stakeholders.

\section{B-2.3 Nevada National Security Site}

The Nevada National Security Site (NNSS) (formerly known as the Nevada Test Site) occupies approximately $1,375 \mathrm{mi}^{2}$ in southeastern Nye County, Nevada. The site is operated by DOE and regulated under DOE Order 435.1 for radioactive waste management. The State of Nevada participates in review of waste material profiles and has access to LLW disposal waste information through an Agreement in Principle with DOE (DOE-NV 1999). Not all of the INL remote-handled LLW meets the action level elements of the NNSS WAC. However, the wastes that exceed the NNSS WAC radionuclide action levels are candidates for special performance assessments (PAs) to

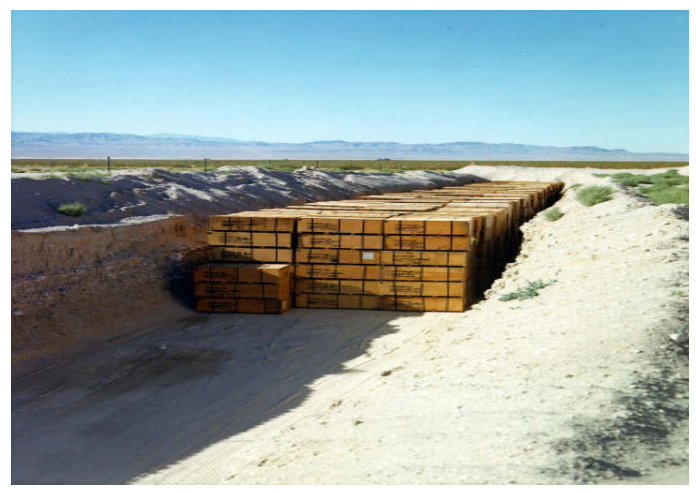
authorize disposal. The NNSS identified no issues that would cause the state to view the activated metals as unacceptable for disposal, although the facility has not received routine shipments of high-radiation waste of this nature in the past. The facility is scheduled to operate through the year 2027 under DOE's Office of Environmental Management and then would be transferred to DOE's National Nuclear Security Agency. Waste is disposed of in trenches. 


\section{B-2.4 Hanford Low-Level Waste Burial Grounds}

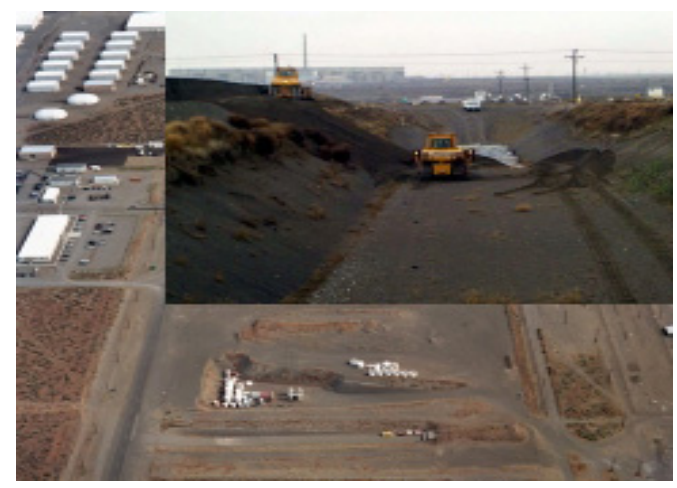

The Hanford LLW Burial Grounds on the Hanford site in Washington are operated by DOE and regulated under DOE Order 435.1 for radioactive waste management. Receipt of offsite waste for disposal at the LLW burial grounds is limited by DOE's agreements with the State of Washington to specific Naval reactor components and certain Hanford and Pacific Northwest National Laboratory waste (DOE-WA 2006). DOE is proposing that these limits on offsite waste importation will be maintained until a Hanford Consent Decree and Tri-Party Agreement milestone of December 31, 2022, is achieved for initial operations of the Waste Treatment Plant for tank waste (DOE 2009).

This milestone is well beyond the mission need for continuous remote-handled LLW disposal capability at the end of Fiscal Year (FY) 2017. The Settlement Agreement had previously limited the importation of offsite wastes for disposal at Hanford to specific Navy reactor components from Pearl Harbor and Puget Sound, return of certain Hanford wastes, and waste from DOE work at Pacific Northwest National Laboratory waste (DOE-WA 2006). Therefore, the Hanford facility is not available for importation of INL's waste and cannot satisfy the mission need for continuous disposal of INL's remote handled LLW.

\section{B-2.5 Environmental Management Waste Management Facility}

The Environmental Management Waste Management Facility (EMWMF) is located on the DOE Oak Ridge Reservation in Tennessee. EMWMF is limited to the receipt of waste from cleanup activities at Oak Ridge and has been in operation since 2002. Management oversight of the EMWMF is the responsibility of DOE, the state, and the Environmental Protection Agency (EPA) under the requirements of the Comprehensive Environmental, Compensation, and Liability Act (CERCLA) (42 USC § 9601) and Resource Conservation and Recovery Act (RCRA) (42 USC $\S 6901$ et seq.). EMWMF is designed

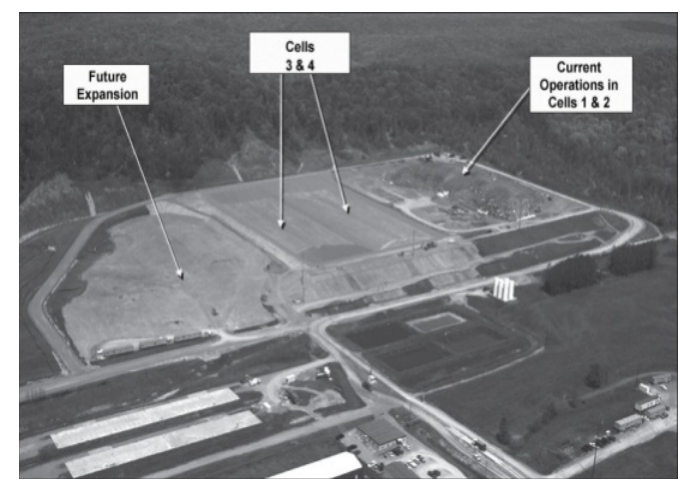
to accept LLW and waste containing hazardous constituents. Since the EMWMF is not authorized to accept waste from any waste generators off the facility site, this facility cannot accept any of the INL remote-handled LLW at this time or in the foreseeable future.

\section{B-2.6 Barnwell}

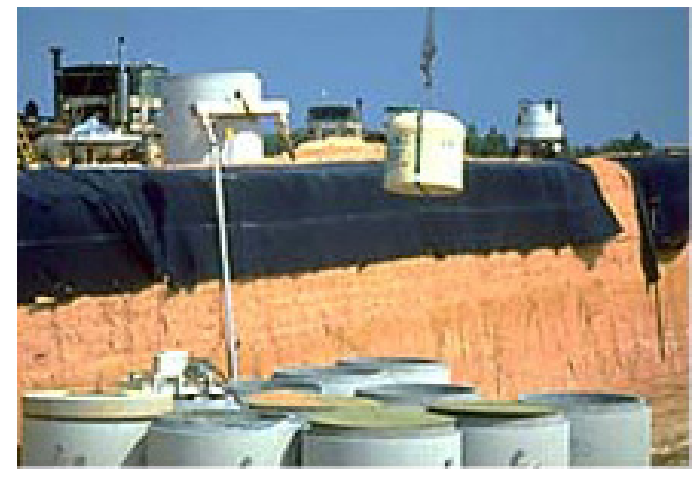

The Barnwell Facility, located in Barnwell County, South Carolina, is operated by EnergySolutions under a lease and license issued by the State of South Carolina. The facility is licensed to accept a broad range of LLW for disposal. However, since June 30, 2008, Barnwell is allowed to accept only waste from generating facilities within the States of South Carolina, Connecticut, and New Jersey (i.e., the members of the Atlantic Compact). Therefore, this facility cannot accept any of the INL remote-handled LLW at this time or in the foreseeable future. 


\section{B-2.7 Waste Control Specialists}

Waste Control Specialists (WCS) is a facility located in Andrew County, Texas, that will support disposal of federal LLW and Texas Compact waste in separate landfill cells. The State of Texas (the NRC authorized licensing authority) issued WCS a license for disposal of LLW on September 10, 2009, conditioned on completion of several administrative requirements. The facility is expected to be opened to LLW disposal in late 2010.

Texas has a state law that requires DOE to take possession of

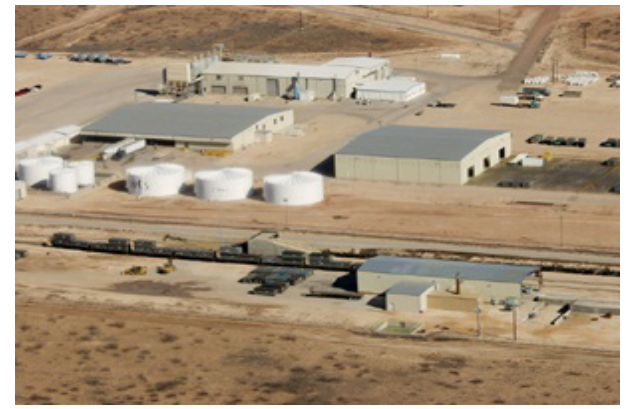
the site after closure, if a "federal waste" site is opened. DOE and the Texas Commission on Environmental Quality have signed a Memorandum of Agreement recognizing their respective responsibilities in the event DOE exercises its discretion to use the WCS Federal Waste Facility (FWF) for LLW disposal. While the Memorandum of Agreement recognizes the rights and responsibilities of the parties, the DOE retains sole discretion on whether to award a prime contract for waste disposal to WCS, and whether to dispose any LLW or mixed LLW at the FWF. Therefore, whether the WCS facility will be selected by DOE for disposal of any LLW is unknown. As with the U.S. Ecology facility, a portion of the remote-handled activated metal waste is expected to exceed the disposal acceptance requirements at the WCS facility. Not all of the INL's remote-handled LLW activated metals waste meets the facility WAC.

The State of Texas will regulate the maximum quantity and schedule of waste that may be disposed of at the FWF through Texas regulations and conditions in the License. The facility does appear to provide a possible future option for disposal of much of the INL remote-handled LLW. However, there is significant risk that the facility will not be able to meet the entire Mission Need because DOE may elect not to use the facility or may limit the quantities or types of waste for disposal to limit its liabilities with respect to final decommissioning of the FTF, when DOE will have to accept title to the facility.

\section{B-2.8 Savannah River Site}

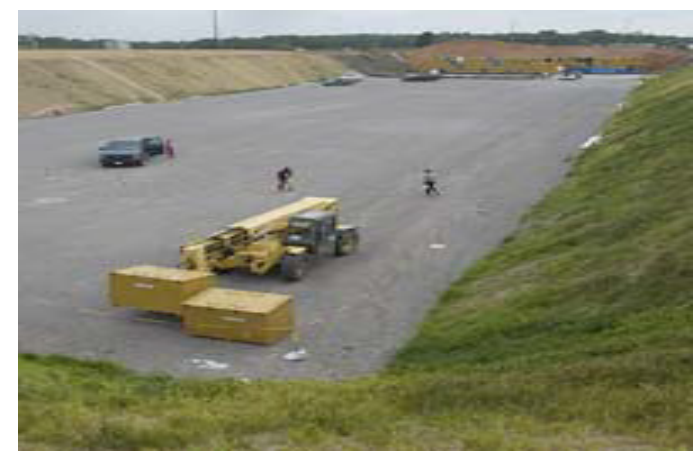

The Savannah River Site (SRS) LLW disposal operations are located in the central part of the Savannah River Site in South Carolina. The disposal facility is regulated by DOE under DOE Order 435.1. It includes engineered concrete vaults for low-activity and intermediate-activity waste disposal. LLW is also disposed of in trenches if it is very low in radioactivity. The trenches are equipped with a sump to sample and collect runoff. In support of the Navy's mission, Savannah River Site accepts remotehandled LLW generated by the Naval Nuclear Propulsion Program from offsite. The SRS is not open to disposal of any other offsite waste. The DOE's Office of Environmental Management baseline for SRS has a planned facility closure date of 2031.

Under DOE's Record of Decision (ROD) regarding treatment and disposal of LLW and mixed LLW (DOE 2000), SRS was designated as a DOE site that would continue, to the extent practicable, with onsite disposal of its own LLW. Along with the INL, the SRS was also designated as a site that, consistent with current practice, would continue to receive and dispose of LLW generated by the Naval Nuclear Propulsion Program. Therefore, SRS could accept the NRF remote-handled LLW waste for disposal by truck or rail. Offsite LLW that did not originate with the Naval Reactor Program cannot be accepted at SRS, which means the INL remote handled LLW generated from the Advanced Test Reactor (ATR) and Materials and Fuels Complex (MFC) would be not be eligible and would have to be disposed elsewhere. 
Because only radionuclide content that meets the limits established by the SRS PA are acceptable, a complete assessment of radionuclide content of the NRF waste would have to be performed. The viability of using a special PA for waste that does not meet the current PA would need to be determined. In addition, the EM baseline for ending facility operations for the disposal facility is 2031. While there may be no technical reason that the facility could not stay open longer, if needed, the PA is based on the 2031 closure date and would need to be reassessed to provide disposal capability out to at least 2037.

To analyze the approach of shipping Naval Reactor activated metals and resins to SRS, INL developed a strategy to transport the remote-handled LLW to SRS by rail, using transport casks that would also serve as disposal containment. This was based on preliminary discussion with SRS and is their preferred approach. This strategy entails the acquisition of NRC certified Model 1 casks, installation of required infrastructure at NRF to accommodate loading of the Model 1 casks, and rail transport and disposal costs. It is assumed that four casks would be needed each year to accommodate the Naval Reactor waste volumes.

Total life-cycle costs for the option of disposal of Naval Reactor activated metals and resins at the SRS are presented in Table B-1. This is a Level or Class 5 cost estimate, which by definition, is used for projects that are up to $2 \%$ of complete definition; at the concept screening phase, based on judgment or parametric models, and with an expected accuracy of -20 to $-50 \%$ for the low end of the range and +30 to $+100 \%$ for the high end of the range. For purposes of this analysis, a cost range of $-30 \%$ to $+50 \%$ is used for the alternative of disposal of Naval Reactors remote-handled LLW at SRS.

Table B-1. Total life-cycle costs for disposal of Naval Reactor-activated metals and resins at the Savannah River Site.

(Millions)

\begin{tabular}{lrrr} 
& Target & Lower Bound & Upper Bound \\
\hline Cask procurement & $\$ 208$ & $\$ 146$ & $\$ 312$ \\
NRC certification for cask & $\$ 1$ & $\$ 1$ & $\$ 2$ \\
NRF infrastructure & $\$ 8$ & $\$ 6$ & $\$ 12$ \\
Transport and disposal & $\$ 352$ & $\$ 246$ & $\$ 528$ \\
\hline Total life-cycle cost & $\$ 569$ & $\$ 399$ & $\$ 854$ \\
\hline
\end{tabular}

Costs for shipping just the Naval Reactor remote-handled LLW offsite to SRS are in the same range as costs for shipping the entire inventory of INL's remote-handled LLW, including remote-handled LLW generated from ATR and MFC to NNSS. Shipping just the Naval Reactors waste to SRS is estimated to have a life-cycle cost of $\$ 569 \mathrm{M}$, while shipments of all waste to NNSS is estimated to have a life-cycle cost of $\$ 556 \mathrm{M}$ (See Appendix C). Costs for casks are significantly higher under the SRS disposal scenario due to the one-time use of each cask for transport and disposal containment. The lifecycle costs for the SRS alternative does not include the additional costs associated with the disposal of the balance of the INL remote-handled LLW (non Naval Reactors) to NNSS.

Because costs for this option do not present a significant advantage over costs of disposing all waste at NNSS, and because this option would increase the complexity of offsite waste disposal due to shipment to and coordination with multiple facilities as well as having to maintain multiple INL waste certification programs, it was not selected for further analysis. However, if offsite disposal at NNSS is selected as the alternative for achieving the INL's mission need, this option can be retained and considered as part of efforts to establish optimal solutions to offsite shipment. 


\section{B-3. SCREENING AND ANALYSIS OF CANDIDATE OFFSITE FACILITIES}

The potential offsite facilities were analyzed relative to DOE Order 413.3B guidance (DOE G 413.3-9, "U.S. Department of Energy Project Review Guide for Capital Asset Projects"). The criteria chosen for the analysis of offsite alternatives are consistent with the criteria applied to the onsite alternatives in Appendix A. These criteria are as follows:

- Risk

- $\quad$ Life-cycle cost

- Complexity

- Stakeholder values

- Regulatory compliance to determine which alternative has the highest probability of meeting the mission need.

This section summarizes the screening results for all of the offsite alternatives and the rationale for selection of one alternative for detailed analysis (Section B-4).

Table B-1 summarizes the results of this screening. In this table, disposal at NNSS is treated as the base case. The NNSS was selected as the base case because it represents the optimum means of achieving the mission need and provides a standard against which all other alternatives can be compared relative to risk, cost, complexity, stakeholder values, and regulatory compliance. Performances of the other alternatives are presented with reference to the base case. For Table B-1, risks are defined as potential events that, if realized, would negatively impact schedule, resources, or performance of the project.

The life-cycle cost of an alternative is defined as the sum total of the direct, indirect, recurring, nonrecurring, and other related costs incurred or estimated to be incurred in the design, development, production, operation, maintenance, support, and final disposition of a major system over its anticipated useful life span. The other alternatives were compared against the cost of shipping to NNSS. For completeness, the other alternatives were evaluated qualitatively for costs (i.e., the likelihood that the costs would be less than, comparable to, or exceed the costs of the base case was generally considered).

To meet the criterion of complexity, there must be confidence that the alternative can be accomplished with minimal coordination with external to DOE entities, transport distances, and interruption of INL generator operations. To meet the criterion of stakeholder value, there must be confidence that the alternative can gain the appropriate level of approval from key stakeholders. To meet the criterion of regulatory compliance, the alternative must be able to be executed in compliance with regulatory requirements.

Table B-2 is a more detailed analysis of the risk considerations for the various offsite alternatives. The ability to completely fulfill the mission need was included in the performance risk of each alternative. Preferable alternatives from a risk point of view are those that eliminate or minimize risks.

The combined analysis for Tables B-1 and B-2 indicate that Barnwell, EMWMF, EnergySolutions, Hanford, SRS, and U.S. Ecology have certain and unavoidable risk that the facility cannot accept all of the INL's waste. WCS also has high risk since the use of the facility by DOE is pending a final decision. Relative to the NNSS base case, these other alternatives are less desirable (e.g., exceed the costs associated with NNSS; have a regulatory constraint). 
Table B-1. Offsite disposal facility screening: comparison to base case of disposal at the Nevada National Security Site.

\begin{tabular}{|c|c|c|c|c|c|}
\hline $\begin{array}{c}\text { Candidate Offsite } \\
\text { Alternative }\end{array}$ & Risk & Complexity & Life-Cycle Costs & $\begin{array}{c}\text { Stakeholder } \\
\text { Values }\end{array}$ & $\begin{array}{l}\text { Regulatory } \\
\text { Compliance }\end{array}$ \\
\hline $\begin{array}{l}\text { Offsite disposal at } \\
\text { NNSS, Nevada }\end{array}$ & $\begin{array}{l}\text { Risks in Base Case include on- } \\
\text { and offsite infrastructure change } \\
\text { delays, increases in disposal } \\
\text { costs, increases in transportation } \\
\text { costs. }\end{array}$ & $\begin{array}{l}\text { DOE has control } \\
\text { State involvement } \\
\text { All waste can be } \\
\text { accepted }\end{array}$ & Offsite base case & $\begin{array}{l}\text { Interstate } \\
\text { Resistance }\end{array}$ & Straight forward \\
\hline $\begin{array}{l}\text { Offsite disposal at } \\
\text { EMWMF, Oak } \\
\text { Ridge, TN }\end{array}$ & $\begin{array}{l}\text { Increases risk to schedule, } \\
\text { resource requirements, and } \\
\text { performance - costs and waste } \\
\text { profile acceptability. }\end{array}$ & NA & NA & $\begin{array}{l}\text { Interstate } \\
\text { Resistance }\end{array}$ & NA \\
\hline $\begin{array}{l}\text { Offsite disposal at } \\
\text { Hanford, WA }\end{array}$ & $\begin{array}{l}\text { Increases risk to schedule, } \\
\text { resource requirements, and } \\
\text { performance - costs and waste } \\
\text { profile acceptability. }\end{array}$ & NA & $\begin{array}{l}\text { Greater than } \\
\text { offsite base case }\end{array}$ & $\begin{array}{l}\text { Interstate } \\
\text { Resistance }\end{array}$ & $\begin{array}{l}\text { Constrained by } \\
\text { Settlement } \\
\text { Agreement. }\end{array}$ \\
\hline $\begin{array}{l}\text { Offsite disposal at } \\
\text { SRS }\end{array}$ & $\begin{array}{l}\text { Increases risk to schedule, } \\
\text { resource requirements, and } \\
\text { performance - costs and waste } \\
\text { profile acceptability. }\end{array}$ & $\begin{array}{l}\text { Coordination with SRS } \\
\text { State involvement } \\
\text { Naval Reactor } \\
\text { Programs waste } \\
\text { acceptable only }\end{array}$ & $\begin{array}{l}\text { Greater than } \\
\text { offsite base case }\end{array}$ & $\begin{array}{l}\text { Interstate } \\
\text { Resistance }\end{array}$ & NA \\
\hline
\end{tabular}


Table B-1. (continued).

\begin{tabular}{|c|c|c|c|c|c|}
\hline $\begin{array}{c}\text { Candidate Offsite } \\
\text { Alternative }\end{array}$ & Risk & Complexity & Life-Cycle Costs & $\begin{array}{c}\text { Stakeholder } \\
\text { Values }\end{array}$ & $\begin{array}{l}\text { Regulatory } \\
\text { Compliance }\end{array}$ \\
\hline $\begin{array}{l}\text { Offsite disposal at } \\
\text { U.S. Ecology }\end{array}$ & $\begin{array}{l}\text { Increases risk to schedule, } \\
\text { resource requirements, and } \\
\text { performance - costs and waste } \\
\text { profile acceptability. }\end{array}$ & $\begin{array}{l}\text { State of Washington } \\
\text { licensed facility } \\
\text { Cannot take all the } \\
\text { waste }\end{array}$ & $\begin{array}{l}\text { Greater than } \\
\text { offsite base case }\end{array}$ & $\begin{array}{l}\text { Interstate } \\
\text { Resistance }\end{array}$ & $\begin{array}{l}\text { State regulator buy- } \\
\text { in required to } \\
\text { receive DOE waste }\end{array}$ \\
\hline $\begin{array}{l}\text { Offsite disposal at } \\
\text { Waste Control } \\
\text { Specialists Texas }\end{array}$ & $\begin{array}{l}\text { Increases risk to schedule, } \\
\text { resource requirements, and } \\
\text { performance - costs and waste } \\
\text { profile acceptability. }\end{array}$ & $\begin{array}{l}\text { State of Texas licensed } \\
\text { facility } \\
\text { DOE and state } \\
\text { coordination }\end{array}$ & $\begin{array}{l}\text { Greater than } \\
\text { offsite base case } \\
\text { Added } \\
\text { transportation } \\
\text { Disposal costs } \\
\text { unknown }\end{array}$ & $\begin{array}{l}\text { Interstate } \\
\text { Resistance }\end{array}$ & $\begin{array}{l}\text { DOE decision on } \\
\text { use of site is } \\
\text { needed }\end{array}$ \\
\hline
\end{tabular}

Definitions:

1. Risk - Can the alternative eliminate or minimize risks? Risks are defined as events that negatively impact schedule, resources or performance of the project.

2. Life Cycle Cost - The sum total of the direct, indirect, recurring, nonrecurring, and other related costs incurred or estimated to be incurred in the design, development, production, operation, maintenance, support, and final disposition of a major system over its anticipated useful life span. Where the alternative anticipates use of existing sites or facilities, consideration of restoration and refurbishment costs is included.

3. Complexity - Can the alternative be achieved with minimal coordination with external agencies and vendors, transport, and interference with INL or tenant operations?

4. Stakeholder values - Can the alternative gain the appropriate level of approval from key stakeholders?

5. Regulatory Compliance - Can the alternative be executed in compliance with regulatory requirements? 
Table B-2. Relative risk results of offsite remote-handled low-level waste disposal alternatives.

\begin{tabular}{|c|c|c|c|}
\hline $\begin{array}{l}\text { Candidate Offsite } \\
\text { Alternatives }\end{array}$ & Schedule $^{\mathrm{a}}$ & Resources $^{\mathrm{b}}$ & Performance $^{c}$ \\
\hline \multirow{4}{*}{$\begin{array}{l}\text { Offsite disposal at NNSS, } \\
\text { Nevada }\end{array}$} & $\begin{array}{l}\text { Schedule could be adversely impacted } \\
\text { by }\end{array}$ & $\begin{array}{l}\text { Resource requirements could be } \\
\text { increased by: }\end{array}$ & $\begin{array}{l}\text { Performance could be adversely } \\
\text { affected by: }\end{array}$ \\
\hline & 1. Infrastructure change delays & 4. Infrastructure change delays & 7. Infrastructure design changes \\
\hline & 2. Funding shortfall & 5. Changes in disposal costs & and delays \\
\hline & 3. Unacceptable waste profile. & 6. Changes in transportation costs. & 8. Unacceptable waste profile. \\
\hline $\begin{array}{l}\text { Offsite disposal at } \\
\text { Barnwell, South Carolina }\end{array}$ & $\begin{array}{l}\text { Relative to disposal at NNSS: } \\
\text { No change to risks } 1 . \\
\text { Increase to risk } 2 \text { due to higher waste } \\
\text { disposal costs and transportation. } \\
\text { Realization of risk } 3 \text { is certain and } \\
\text { unavoidable. }\end{array}$ & $\begin{array}{l}\text { Relative to disposal at NNSS: } \\
\text { No change to risks } 4 \text {. } \\
\text { Increase to risks } 5 \text { and } 6 .\end{array}$ & $\begin{array}{l}\text { Relative to disposal at NNSS: } \\
\text { No change to risk } 7 \text {. } \\
\text { Realization of risk } 8 \text { is certain and } \\
\text { unavoidable. }\end{array}$ \\
\hline $\begin{array}{l}\text { Offsite disposal at Oak } \\
\text { Ridge, TN }\end{array}$ & $\begin{array}{l}\text { Relative to disposal at NNSS: } \\
\text { No change to risks } 1 . \\
\text { Increase to risk } 2 \text { due to higher waste } \\
\text { disposal costs and transportation. } \\
\text { Realization of risk } 3 \text { is certain and } \\
\text { unavoidable. }\end{array}$ & $\begin{array}{l}\text { Relative to disposal at NNSS: } \\
\text { No change to risks } 4 \text { and } 5 \text {. } \\
\text { Increase to risk } 6 .\end{array}$ & $\begin{array}{l}\text { Relative to disposal at NNSS: } \\
\text { No change to risk } 7 \text {. } \\
\text { Realization of risk } 8 \text { is certain and } \\
\text { unavoidable. }\end{array}$ \\
\hline $\begin{array}{l}\text { Offsite disposal at } \\
\text { EnergySolutions, UT }\end{array}$ & $\begin{array}{l}\text { Relative to disposal at NNSS: } \\
\text { No change to risks } 1 \text {. } \\
\text { Increase to risk } 2 \text { due to higher waste } \\
\text { disposal costs. } \\
\text { Realization of risk } 3 \text { is certain and } \\
\text { unavoidable. }\end{array}$ & $\begin{array}{l}\text { Relative to disposal at NNSS: } \\
\text { No change to risks } 4 \text {. } \\
\text { Increase to risk } 5 \text {. } \\
\text { Decrease to risk } 6 .\end{array}$ & $\begin{array}{l}\text { Relative to disposal at NNSS: } \\
\text { No change to risk } 7 \text {. } \\
\text { Realization of risk } 8 \text { is certain and } \\
\text { unavoidable. }\end{array}$ \\
\hline $\begin{array}{l}\text { Offsite disposal at } \\
\text { Hanford, WA }\end{array}$ & $\begin{array}{l}\text { Relative to disposal at NNSS: } \\
\text { No change to risks } 1 \text {. } \\
\text { Increase to risk } 2 \text { due to higher waste } \\
\text { disposal costs and transportation. } \\
\text { Realization of risk } 3 \text { is certain and } \\
\text { unavoidable. }\end{array}$ & $\begin{array}{l}\text { Relative to disposal at NNSS: } \\
\text { No change to risks } 4 \text { and } 5 \text {. } \\
\text { Increase to risk } 6 .\end{array}$ & $\begin{array}{l}\text { Relative to disposal at NNSS: } \\
\text { No change to risk } 7 \text {. } \\
\text { Realization of risk } 8 \text { is certain and } \\
\text { unavoidable. }\end{array}$ \\
\hline
\end{tabular}


Table B-2. (continued).

\begin{tabular}{|c|c|c|c|}
\hline $\begin{array}{c}\text { Candidate Offsite } \\
\text { Alternatives }\end{array}$ & Schedule $^{\mathrm{a}}$ & Resources $^{\mathrm{b}}$ & Performance $^{c}$ \\
\hline $\begin{array}{l}\text { Offsite disposal at SRS, } \\
\text { SC }\end{array}$ & $\begin{array}{l}\text { Relative to disposal at NNSS: } \\
\text { No change to risk } 1 \text {. } \\
\text { Increase to risk } 2 \text { due to, new facility } \\
\text { costs, higher waste disposal costs and } \\
\text { transportation. } \\
\text { Realization of risk } 3 \text { is certain and } \\
\text { unavoidable. }\end{array}$ & $\begin{array}{l}\text { Relative to disposal at NNSS: } \\
\text { No change to risk } 5 \text {. } \\
\text { Increase to risks } 4 \text { and } 6 .\end{array}$ & $\begin{array}{l}\text { Relative to disposal at NNSS: } \\
\text { No change to risk } 7 \text {. } \\
\text { Realization of risk } 8 \text { is certain and } \\
\text { unavoidable. }\end{array}$ \\
\hline $\begin{array}{l}\text { Offsite disposal at U.S. } \\
\text { Ecology, WA }\end{array}$ & $\begin{array}{l}\text { Relative to disposal at NNSS: } \\
\text { No change to risks } 1 . \\
\text { Increase to risk } 2 \text { due to higher waste } \\
\text { disposal costs and transportation. } \\
\text { Realization of risk } 3 \text { is certain and } \\
\text { unavoidable. }\end{array}$ & $\begin{array}{l}\text { Relative to disposal at NNSS: } \\
\text { No change to risks } 4 . \\
\text { Increase to risks } 5 \text { and } 6 .\end{array}$ & $\begin{array}{l}\text { Relative to disposal at NNSS: } \\
\text { No change to risk } 7 \text {. } \\
\text { Realization of risk } 8 \text { is certain and } \\
\text { unavoidable. }\end{array}$ \\
\hline $\begin{array}{l}\text { Offsite disposal at Waste } \\
\text { Control Specialists Texas }\end{array}$ & $\begin{array}{l}\text { Relative to disposal at NNSS: } \\
\text { No change to risks } 1 \text {. } \\
\text { Increase to risk } 2 \text { due to higher waste } \\
\text { disposal costs and transportation. } \\
\text { Extreme increase to risk } 3 \text { due to } \\
\text { unknown future contract availability or } \\
\text { terms. }\end{array}$ & $\begin{array}{l}\text { Relative to disposal at NNSS: } \\
\text { No change to risks } 4 . \\
\text { Increase to risks } 5 \text { and } 6 .\end{array}$ & $\begin{array}{l}\text { Relative to disposal at NNSS: } \\
\text { No change to risk } 7 \text {. } \\
\text { Extreme increase to risk } 8 \text { due to } \\
\text { unknown future contract } \\
\text { availability or terms. }\end{array}$ \\
\hline $\begin{array}{l}\text { a. Events that could adversely } \\
\text { b. Events that could adversely } \\
\text { c. Events that could adversely }\end{array}$ & $\begin{array}{l}\text { npact the ability to complete the project on the req } \\
\text { apact the resources required to complete the projec } \\
\text { npact the ability to complete the project successful }\end{array}$ & $\begin{array}{l}\text { ired schedule. } \\
y \text { and fulfill the mission need. }\end{array}$ & \\
\hline
\end{tabular}


Table B-3 provides the summary of the analysis results. To be considered credible in the facility screening, an alternative had to be able to meet the mission need by accepting all forms of INL-generated, remote-handled LLW, on a continuous basis, starting no later than October of 2017. Several disposal facilities have the capacity to accept at least part of INL's remote-handled LLW. Although waste can be sent to multiple facilities, such a multiple disposal site strategy would generally increase cost, quality issues, and overall project risk. There would also be little benefit to that strategy since acceptance of all the waste is problem for nearly all offsite candidate facilities. In the final analysis, a credible case for receiving all INL-generated, remote-handled LLW could only be made for one offsite facility, NNSS.

Because the use of special PAs may be able to qualify all of INL's remote-handled LLW for disposal at NNSS, and NNSS is currently available, and it is the most credible alternative, it was selected for further detailed analysis. If NNSS is suitable for all LLW, INL would only need to maintain one certification program for waste shipments, minimizing costs of program administration and oversight. Analysis of costs, risks, and complexity of using NNSS will be considered a best case representative of scenarios in which changed circumstances might permit use of other DOE (e.g., SRS) or commercial options (e.g., U.S. Ecology or WCS) for portions of the INL remote-handled waste, that is, resins or a portion of the activated metal waste.

While NNSS was selected as the offsite option for cost evaluation, other disposal facilities remain an option. The availability and capacity of the other facilities will continue to be evaluated and pursued on an ongoing basis if commencement of offsite disposal occurs. Appendix B of the Low-Level Waste Disposal Alternatives Analysis Report (INL 2006) has a comprehensive screening analysis of facilities for remote-handled LLW disposal relative to commercial WACs. To support the analysis in this appendix, the WACs were reviewed again and verified that any changes that have occurred did not affect the conclusions drawn.

\section{B-4. ANALYSIS OF OFFSITE DISPOSAL OF REMOTE-HANDLED LOW-LEVEL WASTE}

This section presents further detailed evaluation of the potential for offsite disposal of all INL remote-handled LLW at NNSS, including resins generated by ATR and NRF and activated metals generated by ATR, NRF, MFC, and potentially other INL activities. ATR resins are already being disposed of at NNSS. To be credible as a disposal path for the remainder of the INL remote-handled LLW, the necessary documentation, procedures, and infrastructure must be in place prior to October 2017 when the SDA vaults are no longer available. Activated metals pose the greatest challenge to offsite disposal due to the amount of shielding required for transportation and transfer operations.

\section{B-4.1 Assumptions and Strategies}

Assumptions and strategies used to develop this alternative include the following:

- Based on the current CERCLA closure schedule, the planning date for closure of the remote-handled LLW vaults is 2017.

- Disposal of INL remote-handled LLW will be required at least through the year 2037.

- Waste profiles will be developed by INL waste generators and approved by NNSS.

- A maximum exposure rate of $30,000 \mathrm{R} / \mathrm{hr}$ for the remote-handled LLW activated metals is selected for purposes of analysis. Projections indicate that future radiation levels are expected to be below this level. Any waste that is over $30,000 \mathrm{R} / \mathrm{hr}$ will be handled on a case-by-case basis. 
Table B-3. Summary of credibility screening results of remote-handled LLW offsite disposal alternative.

\begin{tabular}{|c|c|c|}
\hline Disposal Alternative & Credible? & Summary Rationale for Credibility Conclusion \\
\hline Barnwell, South Carolina & No & $\begin{array}{l}\text { This commercial facility ceased accepting LLW from states outside the Southeast Compact in } 2008 . \\
\text { Unacceptable risk ( } 413.3 \mathrm{~B} \text { criterion). }\end{array}$ \\
\hline $\begin{array}{l}\text { EMWMF, Oak Ridge, } \\
\text { Tennessee }\end{array}$ & No & $\begin{array}{l}\text { This DOE facility is not authorized to accept waste from generators off the Oak Ridge site. } \\
\text { Unacceptable risk ( } 413.3 \mathrm{~B} \text { criterion). }\end{array}$ \\
\hline $\begin{array}{l}\text { EnergySolutions } \\
\text { Clive, Utah }\end{array}$ & No & $\begin{array}{l}\text { Neither the remote-handled LLW resin waste stream nor the activated metals waste stream is able to meet } \\
\text { the facility WAC. } \\
\text { Unacceptable risk ( } 413.3 \mathrm{~B} \text { criterion). }\end{array}$ \\
\hline $\begin{array}{l}\text { LLW Burial Grounds, } \\
\text { Hanford, Washington }\end{array}$ & No & $\begin{array}{l}\text { This DOE facility is authorized to accept only limited, specific wastes from offsite generators. This } \\
\text { authorization does not include any wastes from INL. DOE's preferred alternative for waste management } \\
\text { provides for continuation of the Settlement Agreement limits on disposal of offsite-generated LLW until a } \\
\text { Hanford Consent Decree and Tri-Party Agreement milestone of December } 31,2022 \text { is achieved for initial } \\
\text { operations of the Waste Treatment Plant for tank waste (DOE 2009). Therefore, this facility is not } \\
\text { available and cannot satisfy the mission need for continuous disposal of INL's remote handled LLW. } \\
\text { Unacceptable risk and significant regulatory issues (413.3B criteria). }\end{array}$ \\
\hline NNSS - base case & Yes & $\begin{array}{l}\text { Remote-handled LLW resins from INL can meet the facility WAC. Although a portion of the } \\
\text { remote-handled LLW activated metals do not meet the facility WAC action levels, the facility's processes } \\
\text { for special PAs will be used to demonstrate that the wastes can meet the facility disposal requirements. } \\
\text { Risk and complexity within DOE control (413.3B criteria) }\end{array}$ \\
\hline SRS & No & $\begin{array}{l}\text { This DOE facility is not authorized to accept the remote-handled LLW resins waste from generators off } \\
\text { from SRS. Only NRF remote-handled LLW can be accepted at SRS from offsite. } \\
\text { A portion of the remote-handled LLW activated metals from INL are not able to meet the facility WAC. } \\
\text { Unacceptable risk, increased cost, and increased complexity ( } 413.3 \mathrm{~B} \text { criteria). }\end{array}$ \\
\hline
\end{tabular}


Table B-3. (continued).

\begin{tabular}{ll} 
Disposal Alternative & Credible? \\
\hline U.S. Ecology & $\begin{array}{l}\text { Remote-handled LLW resins from INL can meet the facility WAC. } \\
\text { A portion of the remote-handled LLW activated metals are not able to meet the facility WAC. In addition, } \\
\text { Washington state regulator buy-in would be required to receive any INL waste at this commercial site. } \\
\text { Unacceptable risk, increased cost, increased complexity, and regulatory issues (413.3B criteria). }\end{array}$ \\
\hline WCS & $\begin{array}{l}\text { Remote-handled LLW resins from INL and a portion of the remote-handled LLW activated metals can } \\
\text { meet the facility WAC. However, this facility is unailable for INL waste disposal until DOE reaches a } \\
\text { decision to accept post-closure responsibility for the federal waste facility and issues a contract to WCS } \\
\text { specifying the types of department wastes authorized for disposal. } \\
\text { Unacceptable risk, increased cost, increased complexity, and regulatory issues (413.3B criteria) }\end{array}$ \\
\hline
\end{tabular}

